\title{
A Mixture or a Compound? Community-Level Antecedents of Firms' Category-Spanning Strategies
}

\section{Heewon Chae}
A dissertation submitted in partial fulfillment of the requirements for the degree of
Doctor of Philosophy (Business Administration) in the University of Michigan 2016

Doctoral Committee:

Associate Professor Edward B. Smith, Co-Chair, Northwestern University Professor James D. Westphal, Co-Chair

Professor Gautam Ahuja

Professor Gerald F. Davis

Professor Mark S. Mizruchi 
(C) Heewon Chae 2016 


\section{DEDICATION}

To my parents, Sookwhan Woo and Soodong Chae 


\section{ACKNOWLEDGEMENTS}

With tremendous help and guidance from numerous people, a clueless newbie has learned work from great scholars and got to have passion for academic career. Though only my name appears on the cover of this dissertation, a great many people have contributed to its production. Without their help, my academic journey could not have started and continued. I owe my gratitude to all those people who have made this dissertation possible and because of whom my graduate experience has been one that I will cherish forever. Despite their efforts, any flaws that remain are solely my responsibility.

At Ross, I have been privileged to have the guidance of magnificent mentors in my filed, including my committee members Jim Westphal, Ned Smith, Gautam Ahuja, Jerry Davis, and Mark Mizruchi. First, I have been amazingly fortunate to have Jim as my advisor. Jim has shown me every nitty-gritty of being a top notch scholar. Needless to say that his marvelous academic insight and knowledge have held me to a high research standard, his support and patience have helped me overcome many crisis situations and finish this dissertation. He must be one of the world's busiest men but he has been always there for me. I am truly grateful for his dedication, thoughtful advice, and scholarly inspiration. I hope that one day I would become as good an advisor to my students as Jim has been to me. 
The very first idea of this dissertation came up during a casual conversation with Ned. While collaborating several projects with him, I could learn from him every step to conduct first-rate research, learn to truly enjoy research, and find my dissertation topic that I am passionate about. He gave freedom to explore on my own and at the same time the guidance to recover when my steps faltered. He has been a fantastic advisor and the best coworker I have ever met, but in addition to that, I am so grateful that he has never hesitated to be my good friend who cares my personal as well as academic life. Gautam with his keen insight and vast knowledge has challenged me to aim for a higher level of contribution and to have a balanced perspective between strategy and organization theory. Also, he has always been a fatherly figure to me, who I could rely on away from home. It was Jerry who gave me an eye-opening guide to the larger literature of organization theory, which now has become my main theoretical ground. I cannot emphasize enough how privileged I was to take his organization theory seminar course and deeply appreciate his detailed and prompt comments and advice to my clumsy arguments and ideas. Last but not least, I have tremendously benefited from Mark’s careful reading of and insightful comments on my manuscripts. Since I took his statistical method class in 2011, he has been always there to listen and give advice for any issue from selecting courses to selecting a job. Again, I cannot thank enough all of my committee members who are the world's best scholars yet never hesitate to give support and advice.

I am also indebted to other faculty members at the University of Michigan. I owe Michael Jensen my initial interest and training in the sociological approach to strategy. Minyuan Zhao’s seminar course inspired me to initiate another working project on the international automotive industry and she has been generous to give constructive 
comments and feedback. Sue Ashford's encouragement has brought me back on track at times of setback. Seth Carnahan, Maggie Zhou, Amy Nguyen-Chyung, Jim Ostler, Felipe Csaszar, Brian Wu, Hart Posen, Sendil Ethiraj, and Greta Krippner attended my talks and provided me with insightful comments from different perspectives. Research grants from the Rackham Graduate School and Ross School of Business supported my data collection. Jim Westphal and Ned Smith were generous enough to share his own research funding with me.

I am also grateful for my fellow (former and present) Ph.D. students, Sun, Jihoon, Suntae, Naeun, Hakjin, John, Heeyon, Ken, Gigi, Yoonju, Albert, Sara, Guy, Yonghyun, Gareth, Casidhe, Saerom, Eun Woo, Raji, Harsh, Cha, and Aseem, whom I have learned from and who provided me with the emotional support to bring me back on track at difficult times. My heartfelt appreciation also goes to my lifetime friends Tazo (Saerom), Seungyeon, and Yujin, who never mind listening to me whining on the phone for hours.

Most importantly, none of my academic achievement during my graduate years would have been possible without love and support of my family. Whatever scholarly talent and trait I have, if any, comes from my parents. They have shown, for their whole lifetime, a strong work ethic, perseverance, and generosity and love to others. To my sister Hyewon (my forever idol), my parents, grand parents, parents in-law, Jonghyun, Hyejin, and Minho, I owe much for having a faith in me and supporting me.

Above all, I don’t even want to imagine my graduate years without Kookjin, the love of my life. He has never expressed a single complaint to his wife preoccupied and overwhelmed with her own troubles. Instead, he has given his full incredible love and support. Sometimes with silly slapstick humors and sometimes with cutting-edge 
computing knowledge, he comforted my feelings and practically helped my research. This dissertation is dedicated to him and my family for their sacrifice, faith, and love. 
TABLE OF CONTENTS

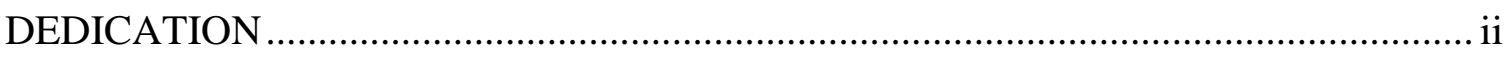

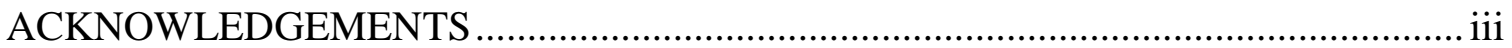

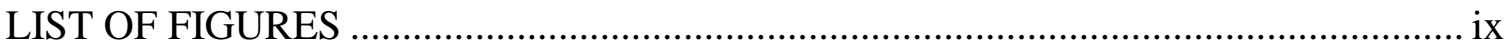

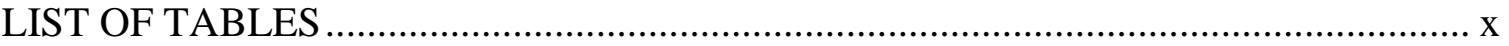

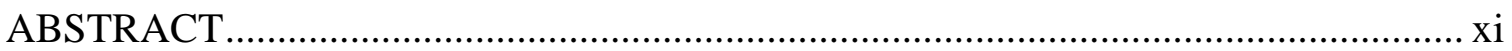

CHAPTER 1. Introduction................................................................................... 1

CHAPTER 2. Two Levels of Category Spanning: Diversification and Differentiation... 11

CHAPTER 3. Antecedents of Category Spanning …………………………………....... 16

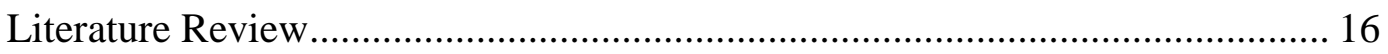

CHAPTER 4. Study 1: The Effect of Consumers' Economic and Social Status on Firms' Category Spanning.............................................................................................. 21

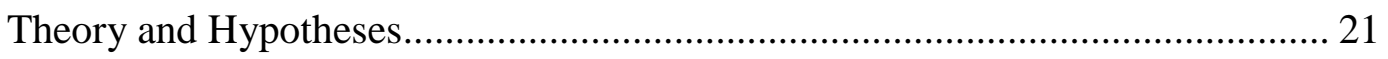

Consumers' economic status and market potential.................................... 21

High levels of education and cultural omnivorousness .............................. 25

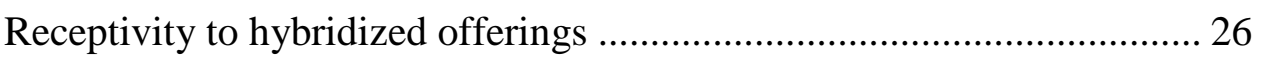

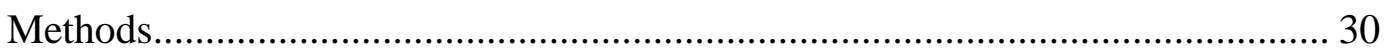

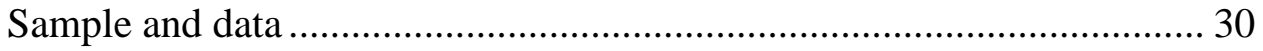

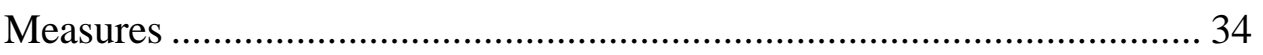

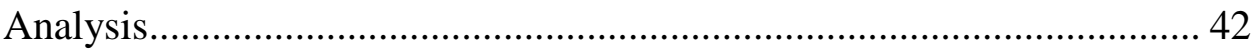

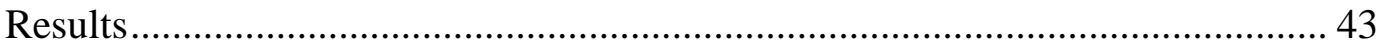

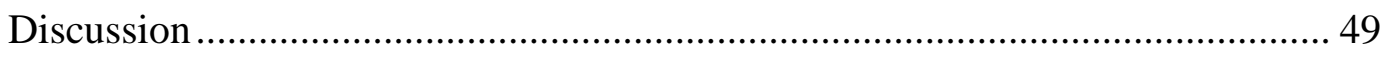


CHAPTER 5. Study 2: Category Population and Firms’ Spanning ............................... 52

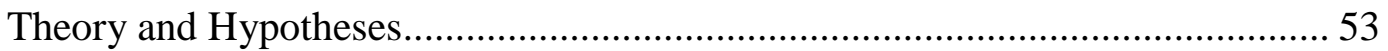

Category population and organization-level spanning ......................... 56

Category population and product-level spanning ............................... 57

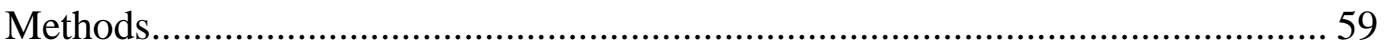

Sample and data ..................................................................... 59

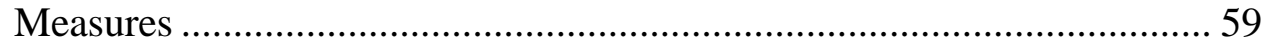

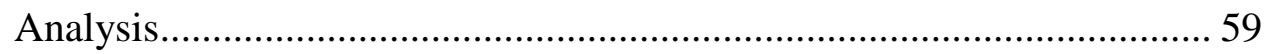

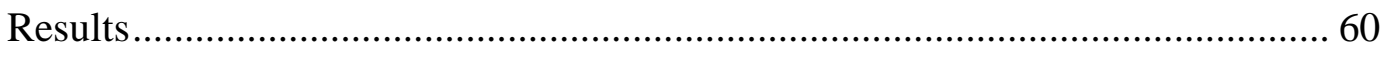

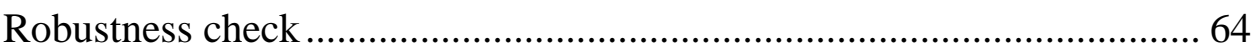

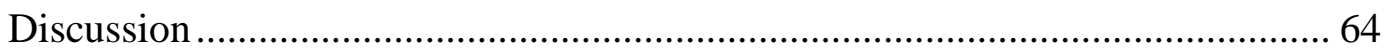

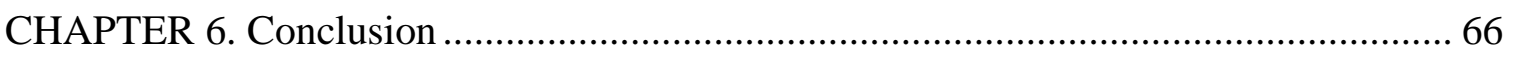

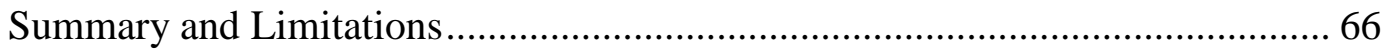

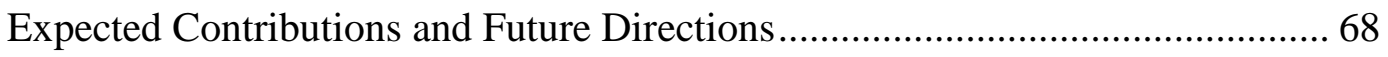

Importance of community-level antecedents ......................................6 68

Two levels of spanning and different types of spanners ........................ 70

Enduring existence of category spanners......................................... 71

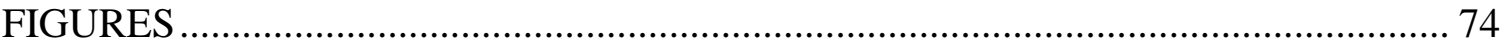

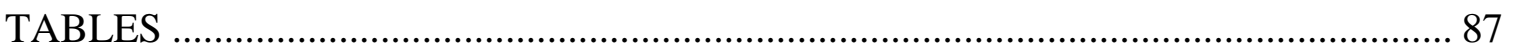

APPENDIX 1. Calculation of Product-level Spanning ............................................ 96

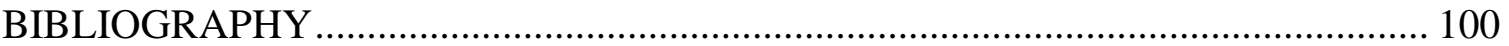




\section{LIST OF FIGURES}

Figure 1. Levels of Category Spanning ...................................................................... 74

Figure 2. Illustration of the Format of Restaurant Menus on Allmenus.com .................... 75

Figure 3. Examples of Restaurants' Category Spanning.................................................... 76

Figure 4. MDS Plot of the Resaurant Industry in the DC-VA-MD-WV Metropolitan Area, by 108 Culinary Styles ........................................................................................ 77

Figure 5. Enlarged MDS Plot of the Restaurant Industry in the DC-VA-MD-WV Metropolitan Area (31 Culinary Styles Positioned in the Center of Figure 4) ......... 78

Figure 6. Correspondence Analysis on a Selected Set of Words for Three Culinary Styles 79

Figure 7. Scatterplot of Organization- and Product-level Spanning of the Sample

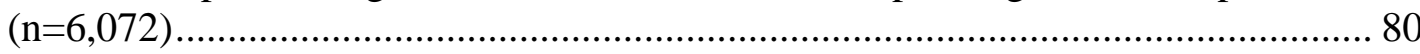

Figure 8. Part of the Menu of Noodles \& Company in Washington, DC .......................... 81

Figure 9. Part of the Menu of Teaism in Washington, DC ................................................. 82

Figure 10. Contrasting Effect of Income and Education on Organization-level Spanning 83

Figure 11. Positive Effect of Education on Product-level Spanning ................................. 84

Figure 12. Curvilinear Effect of Category Population on Organization-level Spanning.. 85

Figure 13. Curvilinear Effect of Category Population on Product-level Spanning .......... 86 


\section{LIST OF TABLES}

Table 1. 108 Cuisine Categories Listed on Yelp for the Sample Region ......................... 87

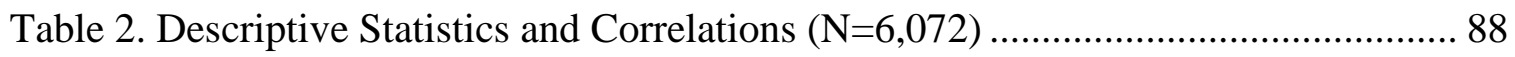

Table 3. GLM Regression Predicting Organization-level Spanning (H1, H2)................ 90

Table 4. GLM Regression Predicting Organization-level Spanning (Robustness Check) 91

Table 5. GLM Regression Predicting Product-level Spanning (H3, H4) ....................... 92

Table 6. GLM Regression Predicting Product-level Spanning (Robustness Check)........ 93

Table 7. GLM Regression Predicting Organization-level Spanning (H5)....................... 94

Table 8. GLM Regression Predicting Product-level Spanning (H6) .............................. 95

Table A 1. Hypothetical Example of a List of Restaurants ........................ 96

Table A 2. Occurence Table .................................................. 97

Table A 3. Word Typicality:The Jaccard Similarity Index for All Word-Category Pairs 98

Table A 4. Dish Typicality and Product-level Spanning of Restaurants 5 and 6 ........99 


\begin{abstract}
This dissertation examines community-level antecedents of firms’ market diversification and product differentiation strategies using the concept of category spanning. Exploiting novel and extensive data on the restaurant industry in a large metropolitan statistical area, I find a contrasting effect of economic and social status of consumer communities on firms’ market diversification. Results show a negative effect of residents' income levels and a positive effect of their education levels on the business scope of the restaurants in a focal town. Also, results from a computational text analysis of every word used in the menus of the sample restaurants suggest that it is educated social elites, culturally omnivorous and seeking novelty, who encourage firms to engage in product hybridization. Next, category population is found to have curvilinear relationships with firms’ category spanning. Results suggest that category population has an inverted U-shaped association with firms’ diversification while it has a U-shaped association with product hybridization. Examining the full spectrum of the demand side and the competitive and institutional pressures arising from category population with a novel theory and operationalization of spanning, this dissertation complements the traditional focus in strategy research on the internal determinants of boundary spanning and contributes to understanding sociological and contextual factors influencing the development of firms’ sustainable competitive advantages. The study also has important theoretical and practical implications for questions ranging from the nuanced effects of
\end{abstract}


the demand and competition of local communities on firm strategy to the enduring existence of different types of category spanners. 


\section{CHAPTER 1.}

\section{Introduction}

What factors influence firms to span market categories? Categories and category spanning in markets are thriving topics across a number of literatures within management and the sociology of organizations (e.g., Bowers 2015; Negro, Koçak, and Hsu 2010; Cattani, Porac, and Thomas 2015; Vergne and Wry 2014). Most studies on category spanning have focused on analyzing its consequences and investigated how category spanning influences organizational performance such as stock market outcomes (Berger and Ofek 1995; Lang and Stultz 1994; Wernerfelt and Montgomery 1988; Zuckerman 1999), firm values (Litov, Moreton, and Zenger 2012), sales (Hsu 2006), and audience evaluation (Leung and Sharkey 2014; Negro, Hannan, and Rao 2010). The main finding of these studies has been that category spanners_organizations "whose features and actions cause them to be assigned to multiple categories” (Kovács and Hannan 2010, 175) — have lower chances of success and survival (Dobrev, Kim, and Hannan 2001; Hsu, Hannan, and Koçak 2009; Wry, Lounsbury, and Jennings 2014), a phenomenon known as the "categorical imperative” (Zuckerman 1999). According to this line of research, category spanners diffuse their capacities into different domains, diluting a clear category-focused identity and creating confusion about what "type" they are-and thus 
receiving less attention and legitimacy and having lower chances of success. This notion of the categorical imperative has been empirically supported in a variety of contexts (e.g., Leung and Sharkey 2014; Litov et al. 2012; Negro et al. 2010; Rao, Monin, and Durand 2005; Zuckerman 1999).

These findings of the negative consequences of category spanning, however, raise an important economic puzzle: why do some firms span market categories if spanning is detrimental to organizational performance? Indeed, we observe in various business fields that many firms are actively engaging in category spanning. Are the forces of competition so weak that they consistently fail to eliminate category spanners from the market despite their relative inefficiency? Or are there other reasons for them to span market categories? To resolve this puzzle, a more basic question needs to be asked: what factors influence firms to span market categories in the first place? Before investigating the consequences of spanning, my dissertation attempts to understand what factors lead firms to engage in category spanning.

Strategic management research on diversification and firm entry has provided considerable insight into the determinants of firms' spanning activities (e.g., Benner and Tripsas 2012; Penrose 1959; Wernerfelt and Montgomery 1988; Zhou 2011). Indeed, dominant streams of research on strategy—including the resource-based view, evolutionary economics, and agency perspectives—have considered firms' boundary choice to be one of the most important strategic decisions firms make (Aldrich and Herker 1977; Rosenkopf and Nerkar 2001) and have suggested various antecedents of spanning activities. The antecedents are, however, mostly examined from inward-looking perspectives, focusing on internal structures and operations of organizations (Barney 
1991; Nelson and Winter 1973; Wernerfelt and Montgomery 1988; see also Cattani, Porac, and Thomas 2015 for a review) or managerial incentives and monitoring advantages (Jensen and Murphy 1990). While the internal attributes of firms are crucial to their strategy development, external environments are no less important, both providing resources for firms and imposing constraints on them (Caves and Porter 1977; Chandler 1977; DiMaggio and Powell 1983; McGee and Thomas 1986; Pfeffer and Salancik 1978; Porter 1980; Thompson 1967).

By taking an outward-looking perspective, my dissertation attempts to address the question of why firms span market categories and identifies community-level antecedents of firms’ category spanning. Organizations are embedded in external environments, which provide resources for the organizations as well as impose constraints on them (Chandler 1977; DiMaggio and Powell 1983; Pfeffer and Salancik 1978; Porter 1980; Thompson 1967). A wide array of literature on management, industrial organizations economics, and strategic groups (Ahuja and Yayavaram 2011; Caves and Porter 1977; Granovetter 1985; Marquis and Raynard 2015; McGee and Thomas 1986; Meyer and Rowan 1977; Popielarz and Neal 2007; Porter 1980) has demonstrated that organizations form their strategies to reflect these opportunities and constraints. Especially, with regard to organizational forms and boundaries, which are the explicit focus of the dissertation, organizational theorists have developed arguments based on a broad presumption that the diversity of organizational forms reflects the diversity of the environments (cf. Hannan and Freeman 1989). Unfortunately, however, little explicit empirical attention has been given to how organizations carve out their categorical position in the market in response to the opportunities and constraints imposed by the local environment (see Popielarz and 
Neal 2007 for a review). This dissertation attempts to shed some light on how community environments affect the way firms develop their categorical positions in the market and construct their product portfolios.

The effort to examine the influence of external community-level factors is consistent with the recent academic initiative to "reinvigorate the issue of competitive categorization in strategic management research" (Cattani et al. 2015, 6). How a firm is perceived by local audiences and how a firm is perceived compared with its competitors have important implications for strategy formulation, strategy implication, and firm outcomes (Cattani et al. 2015; Hannan et al. 2007; Westphal and Graebner 2010). Firms should find appropriate degrees of category spanning strategies that can appeal to their target audiences, enabling them to achieve sustainable competitive advantages.

In the first study of this dissertation, I investigate demand-side antecedents of firms' category spanning. In particular, I analyze how the economic and social status of local consumer communities influence firms' category spanning. The economic and social characteristics of consumers in local communities are crucial to firms' strategy and success (Adner and Zemsky 2006; Porter 1980; Priem 2007). According to organizational theory, market is an interface between organizations and organizational audiences (Phillips and Zuckerman 2001). Organizations present offerings to the audiences for valuation and consumption, and the audiences screen, select, and consume them. As such, consumers are the ultimate arbiter of value (Drucker 1954; Hayek 1994), and organizations must provide offerings that appeal to them to stay competitive in the market (Priem 2007). Consumers, though, do not have universal criteria for consuming and evaluating organizational offerings. They are embedded in distinct value systems 
based on their economic and social status, and these differences may translate into contrasting responses to the same offering (Bourdieu 1984; DiMaggio and Powell 1983; Fligstein and Dauter 2007). Existing research on the determinants of category spanning, however, has largely treated consumer groups as monolithic and generally ignored mechanisms associated with demand (for exception, see Adner and Zemsky 2006; Kashkooli and Younkin 2014; Zander and Zander 2005).

To complement the existing research, I analyze how organizations vary in their category-spanning strategies in response to the economic and social status of local communities using theories on retail location, categorical identity, and cultural sociology. Economic status and social status are the basic attributes that define consumer groups (Bourdieu 1984; Martineau 1958; Myers, Stanton, and Haug 1971). The economic status of consumers affects their decision-making by directly influencing their budget constraint and purchasing power- the financial ability to buy products and services. As consumers' purchasing power partly determines the size of market potential, it is essential that firms consider consumers' economic status when developing strategies to enter the market. Social status of consumers is also an important factor in decision-making because it shapes their preferences (Bourdieu 1984) and their perception of categorical boundaries (Bryson 1996). According to the literature on economic sociology and the sociology of consumption, differences in economic and social standing leads to differences in evaluation. In other words, the value of the same product or service can be perceived differently depending on the economic and social status of the consumer, and a difference in the perception of categorical boundaries may lead to differences in how category spanners are interpreted and evaluated. While there is generally a high correlation 
between the economic status and the social status of individuals ${ }^{1}$, they are theoretically different concepts and thus the mechanisms by which these two constructs influence firms’ category spanning may be different, which may in turn lead to congruent or contrasting effects on firms' category spanning. I attempt to explicate these mechanisms and investigate the effect of local consumers' economic and social status on firms' category spanning.

After examining the demand-side antecedents of firms' category spanning, I investigate, in the second study, how category population —-i.e. the number of organizations in a given market category—influences firms’ category spanning. Local demand is not the only external factor that affects firms' category spanning. As mentioned earlier, a long tradition of literature on management, industrial organizations economics, and strategic groups has emphasized the importance of competitors on firms' strategy and performance (e.g., Caves and Porter 1977; McGee and Thomas 1986; Porac, Wade, and Pollack 1999). Especially, scholars on neoinstitutionalism and organizational ecology have long argued that the number of organizations matters for a firm in formulating its strategies and success. It influences the intensity of competition and the amount of resources available to organizations (Baum and Singh 1996). Also, it affects the institutional legitimacy of the population, which also enhances the capacity of the organizations to acquire resources as well as imposing institutional pressures on them (Aldrich and Fiol 1994; DiMaggio and Powell 1983; Hannan and Carroll 1992; Meyer and Rowan 1977). Thus, considering the influence of category population, along with

\footnotetext{
${ }^{1}$ As there is usually a high correlation between the economic and the social status of individuals, many studies even in sociology and public health have not distinguished the two concepts and have treated them as a single combined concept such as socioeconomic status (SES) for theoretical and empirical analysis (e.g., Bradley and Corwyn 2002; William and Collins 1995).
} 
that of demand-side characteristics, is necessary to better grasp the complete picture of the opportunities and constraints imposed by the local environment and understand how community environments affect the way firms develop their categorical positions in the market.

Category population has been a major research topic by organizational ecologists since Hannan and Freeman’s early work (1989). They have developed a densitydependence model and investigated organizational founding and failure rates as a function of population density (Hannan and Freeman 1989; Hannan and Carroll 1992). While the density dependence model of the founding and failure rates has received substantial empirical support in a variety of contexts and has strong implications for the population-level dynamics and the birth and the death of organizations (see Baum and Shipilov 2006 for a review), I believe that its implications can go beyond organizational founding and failure (Boeker 1991; Haveman 1993). Since institutional and competitive pressures driven by population density influence incumbents as well as new entrants, the insight may also be applied to the studies of strategy formulation and implementation of incumbent organizations, specifically to category spanning that deals with organizational boundaries and their product features. As such, in the second study, I extend past ecological research by focusing on organizational strategy, rather than organizational births and deaths, and investigate how category population influences organizations to adjust their categorical membership and product properties. Taking a more holistic sociological perspective on competitive landscape and organizational strategy by visiting the confluence of literature in strategic management, organizational ecology, and neoinstitutionalism, this study suggests a more nuanced relationship between category 
population and firms' spanning activities. While existing research in strategic management has emphasized a destructive nature of rivalry at a high level of density (Porter 2008), the ecological and the neoinstitutional perspectives embrace both competition and legitimating aspect of population density (DiMaggio and Powell 1983; Hannan and Carroll 1992; Meyer and Rowan 1977). By considering both aspects of density, this study suggests a curvilinear effect of category population on firms' category spanning.

In theorizing and measuring category spanning in both studies, I consider two different levels simultaneously: organization and product. Previous studies have generally defined and measured firms' degree of spanning using information on their market membership — that is, whether an organization operates in a single market domain or diversifies into multiple market domains (e.g., Hsu et al., 2009; Kovács and Hannan 2010; Zuckerman 1999). This definition corresponds to the question of organizational boundaries and scope and is consistent with the concept of market diversification. However, this line of research has generally overlooked differences that may exist in product features among firms with the same level of diversification. In other words, firms may also engage in category spanning at the product level by blending disparate elements to create hybridized offerings to differentiate themselves from their peer group (Durand and Paolella 2013; Hargadon and Douglas 2001; Kovács and Johnson 2013; Schumpeter 1934; Smith 2011; Smith and Chae 2015). I consider both levels of spanning together and examine how the economic status and the social status of local communities influence firms to determine their organizational boundaries and product features. By so doing, this study identifies different spanning patterns firms take—a specialist, a mixture, $a$ 
compound, and a multi-compund-depending on the extent to which they engage in the two levels of category spanning and contributes to bridging research on categorical and organizational identity and strategy research on market diversification and product innovation (Wry et al. 2014)

I perform quantitative analyses on a detailed and large data set of the restaurant industry, conducting an empirical test of hypotheses using a sample of 6,072 restaurants in 85 towns located in the DC-VA-MD-WV metropolitan statistical area, one of the most socially and economically segregated regions in the United States. While I follow previous literature to measure the degree of organization-level spanning using market membership (Kovács and Hannan 2010; Leahey, Beckman, and Stanko 2014), I create a novel measure for the degree of product-level spanning using word-category collocation mapping, a commonly utilized computational linguistics approach. Results from the analysis generally support my argument.

In what follows, I define two levels of category spanning-i.e., organization- and product-level spanning-, in Chapter 2, elaborate the concept of spanning in which organizations engage to determine their organizational boundaries and product features, and identify different types of category spanners. In Chapter 3, I provide a brief review of the literature on the antecedents of category spanning, paying close attention to research on strategic management and the need for a community-based approach. Then, I derive hypotheses and present findings of Study 1 -i.e. the effect of the economic and the social status of consumers-in Chapter 4. In Chapter 5, I move to Study 2, which analyzes the effect of category population on category spanning. Finally in Chapter 6, I summarize the findings of the two studies, consider limitations, and suggest implications of the findings 
and future directions for research on firm boundaries, differentiation, and location strategy as well as for theories on category spanning. 


\section{CHAPTER 2.}

\section{Two Levels of Category Spanning: Diversification and Differentiation}

Diverging definitions and measures of category spanning have been used as burgeoning literature in organizational theory and strategic management started to investigate firms’ category spanning. Broadly, category spanning can be, and have been, examined in two levels: organization and product (see Figure 1). First, organization-level spanning refers to an extent by which an organization has membership in multiple market categories (e.g., Hannan et al. 2007; Litov et al. 2012; Rao et al. 2005). Firms should decide in what market domains they would operate their business. Some firms pursue their business in a single market category while others may diversify into multiple categories. The degree of organization-level spanning also depends on the similarity of categories in which organizations belong to. Previous studies suggest that two categories are considered closer to each other if they share similar features (e.g. Kovács and Hannan 2010; Leahey et al. 2014). Thus, a firm’s degree of organization-level spanning depends on the number of category memberships it possesses and the similarity of the spanned categories. If a firm spans few market categories, it appeals to a narrow market niche and its degree of spanning will be low. On the other hand, if a firm has membership in multiple and distant market categories, its degree of spanning will be high. 
The concept of organization-level spanning applies to firms’ boundaries and market diversification in strategic management (Montgomery 1979; Rumelt 1974; Wernerfelt and Montgomery 1988). A firm may remain in a single market domain (i.e., no organization-level spanning), conduct related diversification by spanning several close market categories (i.e., some organization-level spanning), or extend its scope to span various and distant markets (i.e., unrelated diversification, high degree of organizationlevel spanning).

\section{INSERT FIGURE 1 ABOUT HERE}

While organization-level spanning is related to decisions about a firm's boundaries and market diversification, firms may also engage in category spanning on the product level by bringing elements from categories outside their focal domain and hybridizing them with those from the focal domain to create new crossbred products (e.g., Hsu 2006; Kovács and Johnson 2013; Smith 2011; Smith and Chae 2015). In this case, product-level spanning can be regarded as a means to product differentiation. In the hybridizing process of product-level spanning, a newly created product develops its own properties that differentiate itself from typical offerings in the focal category. Because the properties of the product violate existing categorical expectations, it may be more difficult to understand and thus deemed less legitimate (Lounsbury and Glynn 2001). However, its novelty (Hargadon and Douglas 2001) may cause it to be regarded as an innovation (Schumpeter 1934). In a study of the film industry, for example, Hsu and her colleagues (2012) argue that films that span genres in innovative ways produce 
exceptional success. Product-level spanning provides firms with a way to differentiate and innovate their products at risk of being ignored, misunderstood, and devalued.

Furthermore, the hybridization by product-level spanning can sometimes pave the way for the emergence of a new market category. The development of the minivan product category is a good example (Rosa, Porac, Runser-Spanjol, and Saxon 1999). Small, boxy front-wheel-drive vans designed for the purpose of transporting people were first developed in the early 1980s by combining features of sedans and trucks. The nascent and unnamed market for such vehicles was crystallized and recognized as a distinct category when J. D. Power and Associates first introduced the "minivan" category label in 1982 after the huge success of Chrysler’s Dodge Caravan.

As such, the two levels of category spanning are associated with different theoretical concepts—-market diversification and product differentiation, respectively ${ }^{2}$. And the distinction between the two levels of category spanning implies that even if firms engage in the same degree of organization-level spanning, their product portfolios may look different depending on the extent to which they engage in product-level spanning. Whereas organization-level spanning determines a firm's overall business boundaries and its scope, product-level spanning provides a way to position its products within those boundaries.

While previous research on category spanning has focused on only one level of spanning over the other (a good exception is Kovács and Johnson 2013; Goldberg et al. 2015), which might contribute to inconsistent findings on its antecedents and consequences, this dissertation considers both levels of spanning simultaneously and

\footnotetext{
${ }^{2}$ Relatedly, Goldberg, Hannan, and Kovacs (2015) also suggest two perspectives on category spanning: variety and atypicality.
} 
identifies different spanning patterns driven by the spanning activities (see Figure 1). First, if a firm does not engage in either level of spanning, it provides typical offerings in a single market category, being a specialist organization. Next, if a firm engages only in organization-level spanning, it provides typical offerings in multiple diversified market categories, being a generalist (Hannan et al. 2007) that looks like a mixture organization (a term borrowed from chemistry) — that is, each product retains its original categoryspecific properties, and the firm provides typical offerings in each of multiple market segments. On the other hand, if a firm engages only in product-level spanning, it provides atypical products that are novel in a given market category it belongs to. In this case, the firm takes the form of a compound organization (another term borrowed from chemistry), with hybridized offerings that are distinct from those of its peers. Similarly, if a firm actively engages both in organization- and product-level spanning, it becomes a multicompound organization that provides hybridized offerings in each of multiple market categories.

Imagine firm A and firm B, both of which conduct business only in the refrigerator market. Firm A produces conventional refrigerators consisting of a cooler section and a freezer section, each with one door. Firm B attaches a soda maker to a door of its refrigerators, making them atypical products in the category. In this case, neither firm engages in organization-level spanning - they both operate in the single market category—but firm B conducts product-level spanning while firm A does not. Next, the two firms decide to diversify into the household fan market. Again firm A does not engage in product-level spanning and offers a very typical type of fans, with mechanical revolving blades connected to a motor and covered by meshed plastic or stainless steel. 
Firm B incorporates a technology using hydrodynamics and creates a fan without blades. Conducting organization-level spanning without product-level spanning makes firm A a mixture organization—-that is, each product retains its original category-specific properties, and the firm provides typical offerings in each of multiple segments. In contrast, firm B actively engages in product-level spanning and takes the form of a multicompound organization, with hybridized offerings that are distinct from those of its peers. As the four patterns of spanners offer products with different degrees of variety and typicality, they would need different antecedents and attract heterogeneous audiences. In the next section, I review previous literature that has implication for understanding antecedents of firms' category spanning and suggest a need to consider community-level factors to better understand firms' likelihood of engaging in different patterns of category spanning. 


\section{CHAPTER 3.}

\section{Antecedents of Category Spanning}

\section{Literature Review}

Several streams of research on strategic management have shed light on antecedents of organizations' category spanning. First and foremost, the resource-based view (RBV) suggests that firms extend their boundaries based on key resources and capabilities they possess (Barney 1991; Benner and Tripsas 2012; Penrose 1959; Wernerfelt and Montgomery 1988). Penrose (1959) argues that rent-seeking firms diversify in response to excess capacity in resources. According to her, firms rarely attain an equilibrium position, or a state of rest, because of resource indivisibility. As long as unutilized resources cannot be sold efficiently on the market (Teece 1980) and expansion provides a way of more profitably employing these resources, a firm has an incentive to expand its organizational boundaries. Under these circumstances, economies of scope arise, and the diversified firm becomes the most efficient form of organizing economic activity. The RBV especially suggests that firms conduct related diversification to maximize profit. Because a resource can support only a limited range of products, diversification into resource-unrelated markets provides limited benefits but yields substantial coordination costs (Montgomery 1985). 
Many empirical studies have supported these arguments of the RBV. They examine the types of resources that motivate firms to diversify (Montgomery and Wernerfelt 1988), the nature of resources that influence modes of diversification (Amit, Livnat, and Zarowin 1989; Chatterjee and Wernerfelt 1991), the relationship between the degree of diversification and firm performance (Markides and Williamson 1994), the organizational structures and processes that support diversification (Kazanjian and Drazin 1987), different measures of relatedness and their consequences on performance (Hall and St. John 1994), and conditions that lead to diversification discount (Lamont and Polk 2002; Miller 2004). As such, the RBV has contributed to our understanding of types, causes, and consequences of firms' boundary spanning with its emphasis on heterogeneous firm-specific resources.

Second, evolutionary economics views category spanning as search and selection activities that seek to upgrade a firm's routines and knowledge base and thereby improve its performance at the corporate level (Dosi 1988; Nelson and Winter 1973). It suggests that low-performing firms have greater incentives to span categories (i.e., problematic search). Duncan and Weiss (1979) argue that although high-performing firms may also engage in search and selection to keep performance high, low-performing firms feel a greater pressure to do so, and the search stimulated by poor performance is guided toward generating knowledge that will help improve the performance (Christensen and Montgomery 1981; Duhaime and Grant 1984). This perspective also suggests that the direction for category spanning is determined by the possibility of utilizing the firm's existing knowledge. This emphasis on the potential fit between the firm's existing knowledge base and the knowledge requirement of the target industry is consistent with 
the economies of scope argument of the RBV.

Evolutionary economics then goes one step further and argues that a firm's knowledge base is extended and changes as the firm acquires additional knowledge from sequential entries to new market categories (Chang 1996; Helfat and Eisenhardt 2004). This notion implies that even when a firm wants to enter an industry whose knowledge requirements are largely dissimilar to the firm's current knowledge base, it can move in that direction by entering several intermediate industries and thereby acquiring additional knowledge bases. The firm can expect to improve its performance as a consequence of sequential diversification led by utilizing its existing knowledge and developing successful routines that can be applied to multiple businesses. These predictions of evolutionary economics are empirically supported by several longitudinal studies (Chang 1996; Chang and Rosenzweig 2001; Christensen and Montgomery 1981; Duhaime and Grant 1984; Kock and Guillén 2001). As such, evolutionary economics adds to the contribution of the RBV by examining not only spatial movements but also temporal movements of firms' boundary expansions to build new routines and knowledge.

While the RBV and evolutionary economics perspectives focus primarily on resources and capabilities firms possess and emphasize the internal structure and operations of the organization as important antecedents of firms' spanning activities, they overlook the power of external audiences in shaping organizational opportunities and constraints. Organizations are embedded in external environments, which provide resources for the organizations as well as impose constraints on them (Chandler 1977; DiMaggio and Powell 1983; Pfeffer and Salancik 1978; Porter 1980; Thompson 1967). A wide array of literature on industrial organizations economics and strategic groups (Ahuja 
and Yayavaram 2011; Caves and Porter 1977; Granovetter 1985; Marquis and Raynard 2015; McGee and Thomas 1986; Meyer and Rowan 1977; Popielarz and Neal 2007; Porter 1980) has demonstrated that organizations form their strategies to reflect these opportunities and constraints. Especially, research in industrial organization economics in 1980s and 1990s (Porter 1980) emphasized market positioning and market power as central concepts that explain firms’ scope and spanning choice. This line of research suggests that internal capital markets lead to a more efficient allocation of resources across multiple business categories and that cross-subsidization can result in increased market power by enabling them to conduct predatory pricing (Tirole 1988). Also, the mutual forbearance hypothesis suggests that multi-market competition by diversifying into multiple businesses may result in the reduction of competitive intensity among rivals (Gimeno and Woo 1999; Scott 1982).

While market power and positioning have been the central topics in industrial economics, influence of other market participants has received relatively scarce attention. Particularly, demand has been treated as given and little attention has been paid to how local consumer heterogeneity influences firms’ motivation to straddle categories (see Adner and Zemsky 2006; Kashkooli and Younkin 2014; Priem 2007; Zander and Zander 2005 for exception). Organizational theorists, in comparison, have developed arguments based on a broad presumption that the diversity of organizational forms reflects the diversity of the environments (cf. Hannan and Freeman 1989). Unfortunately, however, little explicit empirical attention has been given to how organizations carve out their categorical position in the market in response to the opportunities and constraints imposed by the local environment (see Popielarz and Neal 2007 for a review). To 
complement the current research on antecedents of firms' spanning activities, this dissertation attempts to shed some light on how community environments-i.e. various actors in the local community—affect the way firms develop their categorical positions in the market and construct their product portfolios. 


\section{CHAPTER 4.}

\section{Study 1: The Effect of Consumers' Economic and Social Status on Firms’ Category Spanning}

\section{Theory and Hypotheses}

\section{Consumers' economic status and market potential}

An extensive and broad range of theoretical literature has investigated firms' decisions on retail location. Beginning with Hotelling's (1929) simple spatial model of firm location in a linear city and its later modifications (Salop 1979; Stern 1972), research on retail location has focused on spatial and price competition between firms, often using a game-theoretic framework (Chamorro-Rivas 2000; Karamychev and van Reeven 2009). However, while retail location decision naturally concerns local consumers who directly interact with retailers, most formal models of retail location assume identical income levels and homogeneous preferences of consumers, which leads to few predictions about how variations in consumer income and preferences affect specific retail patterns (See Schuetz et al. 2012 for a brief review). A notable exception is research by Davis (2006) and De Palma and colleagues (1994) on the U.S cinema industry and the Canadian videocassette rental market industry, respectively, who develop more flexible models that allow for consumer heterogeneity, non-price competition in the form of various retail patterns, and less-constrained market 
boundaries. The current study also takes a stance in line with the flexible model that accounts for consumer heterogeneity and investigates how firms develop their categoryspanning strategies in response to varying economic and social conditions of neighborhoods.

Poor urban areas are often referred to as "retail deserts” (Schuetz, Kolko, and Meltzer 2012) with limited access to retail goods and services. Media accounts and a few academic studies report a dearth of retail establishments in low-income neighborhoods and suggest that retail establishments are generally more prevalent in affluent neighborhoods than in poor ones (Meltzer and Schuetz 2012; Schuetz et al. 2012; Zukin et al. 2009). However, this difference in density does not directly translate into poor neighborhoods being doomed to retail failure. Some organizations continue to be profitable in low-income neighborhoods (Porter 1995), and high-income neighborhoods do not welcome all types of retail (Walmart, for example, has occasionally incurred local opposition). Thus, an important implication is that firms' strategies to appeal to local communities should vary depending on the neighborhood economic conditions.

The economic status of consumers influences their purchasing power-their financial ability to buy products and services. Income is of course one of the most important factors affecting purchasing power. Higher household income generally implies greater purchasing power among local residents and lower household income implies limited purchasing power, all other things being equal. Previous research, albeit limited, has argued that organizational density will be greater in higher-income neighborhoods where consumer purchasing power is greater and the potential for consumption expenditures is larger. In supporting this argument, Schuetz and colleagues 
(2012) find in a study of 58 large U.S. metropolitan areas that the number of retailers (including supermarkets, drugstores, food service, and dry cleaners) increases with neighborhood income and that neighborhoods that experience a rise in household income witness a growth in the number of retail establishments. Similarly, Meltzer and Schuetz (2012) also find that lower-income neighborhoods in New York City have fewer and smaller retail establishments.

As the overall market potential of lower-income communities is smaller than that of higher-income neighborhoods, organizations in the lower-income communities face the "small market problem" (Hausman and Leonard 1997), which occurs when certain organizations' revenues are not sufficient to cover their costs due to low demand. If an organization located in a low-income neighborhood operates its business only in a single market segment, the potential consumer base will be even smaller, serving a limited segment of consumers in the community. Thus, the organization would be more inclined to extend its business to multiple market segments to attract a larger and more diverse base of consumers.

Organizational niche-width theory supports this prediction. An organization’s niche tells “what regions of a social space a producer can exploit” (Hannan 2010, 166). Organizations targeting a wide range of environmental resources—a wide diversity of consumers—are classified as having broad niches and are labeled "generalists" and those that limit their focus to a tight region in the social space are classified as having narrow niches and are labeled "specialists" (Hannan et al. 2007). The relative fitness of generalists versus specialists differs depending on various environmental conditions (Hannan 2010; Hannan and Freeman 1977). Specialists concentrate their capacities on a 
single market segment to efficiently and reliably perform in the target market niche, while generalists divide their capacities across many different kinds of activities, reducing their potential for performance in each. Specialists are thus expected to outperform generalists in regions they both target.

However, this scenario works only under a stable environment (Hannan and Freeman 1989). Generalists are likely to outlast specialists given a highly variable or unpredictable distribution of resources because they spread risk across multiple segments of the environment and garner attention from a greater number of consumers (Dobrev et al. 2001; Dowell and Swaminathan 2000; Freeman and Hannan 1983; Hsu 2006). In lowincome neighborhoods, demand—or resources that organizations attempt to grasp—-for each market niche is small and unstable. Targeting a specific niche might not enable an organization to garner enough resources to survive. Thus, firms would be more likely to target a broad niche by claiming multiple category membership to accumulate greater attention from potential customers.

On the other hand, the concern about limited purchasing power and consumption expenditure is relatively small for organizations in wealthier communities. Generally, there is a greater and more stable demand — resources for organizations to garner-for each category (Meltzer and Schuetz 2012), and an organization's need to join multiple market categories to attract a larger base of consumers would thus be smaller. Instead, concentrating on a narrow market niche and devoting its capacities to becoming a specialist may be a more effective way to appeal to consumers in a given market segment. 
Hypothesis 1: Firms in lower-income communities are more likely to diversify into multiple market segments than firms in higher-income communities.

\section{High levels of education and cultural omnivorousness}

Education is an important indicator of one's social status and influences one's perception of categorical boundaries (Bourdieu 1984; Bryson 1996; 1997; Katz-Gerro 2002; Lizardo 2005). In the sociology of culture and consumption, research initiated by Peterson and his colleagues argues that since the 1990s, educated individuals have shown a tendency toward cultural omnivorousness—- "an openness to appreciating everything” (Peterson and Kern 1996, 904)—and high levels of cultural tolerance. Burgeoning empirical evidence from the United States as well as from other countries has documented a shift in the orientation of highly educated individuals toward an inclusive range of cultural preferences that traverses categorical boundaries (e.g., Goldberg 2011; Peterson 1992, 1997, 2005; Warde, Wright, and Gayo-Cal 2008).

Peterson and Kern (1996) suggest structural and value change that may have contributed to the shift in social elites' tastes from exclusivity to omnivorousness. First, they argue that education and mass media have made elite aesthetic taste more accessible to wider segments of the population, and the diverse folkways of populations around the world have become "increasingly available for appropriation by elite taste-makers" (Peterson and Kern 1996, 905). Also, entrepreneurs have placed positive value on seeking new and more exotic modes of expression; as a result, such a wide range of aesthetic values have been introduced that the old "single standard became stretched beyond the point of credibility” (Peterson and Kern 1996, 905). In addition, Peterson and 
Kern (1996) suggest that all sorts of discriminatory laws in the United States have been abolished, aiding the diffusion of inclusionist omnivore among social elites.

With these social changes, greater tolerance of difference and understanding the coexistence of multiple values have become virtues that social elites are expected to possess. Highly educated individuals started to express an inclusive taste, and openness to diversity has become “a new cultural logic of distinction” (Goldberg 2011, 1411), a way of differentiating themselves from others. Omnivorousness has become a new aesthetics of elite status that replaced highbrow snobbishness as a means of class distinction (Peterson and Simkus 1992). Today’s social elites seek to acquire and display mobile, open-minded, creative, and reflexive traits that distinguish them from others who are stuck, narrow-minded, traditional, and non-reflexive (Prieur, Rosenlund, and SkjottLarsen 2008). Therefore, having this omnivorous taste, highly educated groups are expected to be more open and favorable to organizations that conduct business in multiple market domains.

Hypothesis 2: Firms in more educated communities are more likely to diversify into multiple market segments than firms in less educated communities.

\section{Receptivity to hybridized offerings}

I suggested earlier that due to the small market potential in lower-income neighborhoods, organizations would attempt to attract a broader base of consumers by claiming membership in multiple market segments. How should they, then, organize their product arrangement to appeal to a broader base of consumers? Will the degree of 
product-level spanning vary between organizations in lower- and higher-income communities?

Product-level spanning often brings novel and unfamiliar offerings to the market. Indeed, innovation does not occur out of nowhere but is often a result of recombining and hybridizing elements from disparate categories and bridging categorical boundaries (Durand and Paolella 2013; Hargadon and Douglas 2001; Schumpeter 1934). But not every recombination pays off. Many attempts at recombination end in failure and offerings that are poorly appreciated (Christensen 1997). Offerings by product-level spanning may be “untested and incompletely understood” (Tushman and Anderson 1986, 444), and product definitions may be ambiguous or unknown (Hargadon and Douglas 2001; Navis and Glynn 2010). Which audience, then, would be more likely to take risks and explore untested, novel offerings?

Sociologists have long argued that rich consumers, often defined as individuals with high socioeconomic status, are more likely to explore novel offerings and create trends (Bourdieu 1984; Simmel 1957). They create fashion, and once a trend begins to be followed by the lower classes, they pursue new trends (Simmel 1957). Importantly, what enables them to do this is their affluence. As mentioned earlier, exploring atypical hybridized offerings is often costly. The relative cost of the exploration for wealthy consumers is small compared to the cost for those who are worse off.

Consumers with lower income, in comparison, do not have the luxury to actively pursue hybridized offerings. Considering their tight budgets, they might make a safer choice by selecting category-typical products that are familiar and conform to their 
established expectations. ${ }^{3}$ Organizations in lower-income neighborhoods would thus have a greater need to provide category-typical offerings to absorb existing demand than to create new demand for unfamiliar hybridized offerings.

Hypothesis 3: Firms in lower-income communities are less likely to engage in product-level spanning than firms in higher-income communities.

I also suggest that organizations targeting highly educated communities will be more likely to engage in product-level spanning for a different reason. As mentioned earlier, the omnivorous taste of social elites influences their perception of categorical boundaries (Bryson 1996) and preferences for hybridized offerings. Research in cultural consumption has demonstrated that the openness of elite omnivores is articulated in several ways, ranging from a passive tolerance of different forms to an active desire to discover new and challenging items (Bryson 1996; Hannerz 1990; Ollivier 2008; Roose, van Eijck, and Lievens 2012; Tepper and Hargittai 2009). In other words, elite individuals' openness entails both "the capacity and willingness to learn and choose as opposed to the inability or unwillingness to do so" (Ollivier 2008, 125). First, it entails competencies and knowledge that enable educated individuals to understand and tolerate difference. This ability leads elites to impose less strong categorical schemas when

\footnotetext{
${ }^{3}$ An alternative theory is that budget-constrained buyers might favor hybridized offerings that retain the original functions of their imported elements because they can reduce their overall cost by not having to buy multiple products to get a variety of functions. Still, this type of hybridized offering can create hedonic value for rich trendsetters due to the very novelty they bring by aggregating disparate functions into one offering, while this novelty may be translated as unfamiliarity and uncertainty by budget-constrained individuals. The scope condition of this hypothesis is explained in more detail in the discussion section.
} 
evaluating products. For them, categories and categorical schemas would be less of a guide to follow strictly and more of a convenient tool to aid comparison and evaluation. They use categories for making decisions but are not simply dominated by the categorical imperative. Exposed to a wide range of values and knowledge, the educated exert more agency when selecting and evaluating organizational offerings and make a conscious decision (Hannerz 1990).

In addition to their ability to better understand hybridized offerings, omnivorousness leads social elites to develop a preference for such offerings (Ollivier 2008). Research in cultural consumption and marketing science has long found a positive relationship between higher levels of education and inclination to seek intellectual stimulation and novel ideas (Bello and Etzel 1985; Chan and Misra 1990; Corey 1971; Rogers 1995; Simmel 1957). Seeking novelty, social elites often create fashion and act as trendsetters who drive demand for new products (Bourdieu 1984; Simmel 1957). They are among the first groups to test, appreciate, and validate innovative offerings, and they then spread the information to a wider array of consumers. Combined with the tendency to pursue novelty, omnivorousness paves the way for the elites to favor crossbred goods in practical or technical domains beyond the arts (Ollivier 2008; Roose et al. 2012). They find hedonic value in consuming innovative hybrids (Bianchi 2002; Bresnahan and Gordon 1997; Nerlove 1995). Product-level spanning may create confusing products that are difficult to understand, but this does not always lead to the categorical imperative. Some audiences—such as educated individuals—may enjoy experiencing and understanding offerings that present a challenge to easy classification. 
Hypothesis 4: Firms in more educated communities are more likely to engage in product-level spanning than firms in less educated communities.

\section{Methods}

\section{Sample and data}

I performed quantitative analyses on a large, detailed data set of the restaurant industry in the DC-VA-MD-WV metropolitan statistical area. The restaurant industry is large and ubiquitous and has social and economic impact on daily life in the United States (Carroll and Torfason 2011). The National Restaurant Association (NRA) forecasts restaurant industry sales to be $\$ 709.2$ billion in 2015 (National Restaurant Association 2015). The industry provides a wide range of products and services and touches nearly every household (Schlosser 2001), and the characteristics of demand are readily reflected in the operations of restaurants. These factors make the industry a highly suitable context to test the effect of consumers' characteristics on firms’ diversification and product hybridization.

In addition to its economic and social significance, the restaurant industry is an excellent empirical setting for several reasons. First, the industry contains submarkets with many culinary styles that appear to be broadly understood and schematized. And restaurants have easily comparable product structures (menus) that are similar enough to be compared meaningfully (Rao et al. 2005). Second, there is ample opportunity to examine hybrid offerings that span categories because many establishments claim to combine multiple cuisine styles and provide novel offerings and are acknowledged by consumers as doing so (Kovács and Johnson 2013). Third, the restaurant industry is a field of fierce competition in which many organizations rise and fall. According to Parsa 
and colleagues (2005), about 26 percent of restaurants fail during the first year of operation, so it is imperative for restaurants to reflect the economic and social conditions of consumers and local communities. Last but not least, I could acquire a large amount of detailed information about the restaurants, including their menus with elaborate description, by extracting data from websites that provide this information in a systematic fashion.

Information on menus is extracted from the website Allmenus, which is the largest local menu guide on the internet and gets more than five million visitors every month. Owned by GrubHub, the website gathers restaurant menus from a variety of sources including restaurant websites, restaurant employee submissions, and its own team of menu collectors, and the menus are formatted in a standard format ${ }^{4}$. (See Figure 2 for an example of menu information provided on Allmenus.) The richness of the data on the menus allowed me to perform a detailed analysis of the product-level spanning of all the industry players in the focal region. Other information on the sample restaurants is collected from Yelp, a major online source of information on local businesses and crowdsourced reviews. All establishments listed in the "restaurants" group on Yelp were included in the sample. All of the information on restaurants was downloaded on February 27, 2014.

INSERT FIGURE 2 ABOUT HERE

\footnotetext{
${ }^{4}$ From www.allmenus.com
} 
The demand-side characteristics are examined at the city level. In the case of retail business, including the restaurant industry, customers are drawn primarily from the immediate vicinity, and establishments thus mostly likely reflect the characteristics of neighborhood residents (DiPasquale and Wheaton 1996). The DC-VA-MD-WC metropolitan area, composed of the District of Columbia and municipalities in 22 counties in Virginia, Maryland, and West Virginia, is one of the most socially and economically segregated metro areas in the U.S. $\left(5^{\text {th }}\right.$ most segregated metropolitan area from the American Community Survey (2008-2012) by U.S. Census Bureau, Florida 2014), so the setting provides enough variance across cities for analysis. Information on city-level characteristics was collected from U.S. Census Bureau data retrieved from the Social Explorer website (socialexplore.com). The final sample included 6,072 restaurants in 85 cities.

Figure 3 illustrates the income and education levels of 85 cities in the sample. Each node represents a city, and the vertical and horizontal lines show the average level of income and education, respectively. As expected, there is a high correlation between the two variables (correlation=0.68), and more cities are positioned in the first and the third quadrants of the graph. The restaurants of five cities (Falls Church, McLean, College Park, Dunkirk, and Beltsville) are included as examples to demonstrate the expected combined effects of income and education on the organization- and productlevel of spanning by restaurants located in a focal town. This illustration is made to give an idea about the general application of the hypothesized effects.

INSERT FIGURE 3 ABOUT HERE 
First, Falls Church and McLean have above-average levels of both income and education. Because education and income are found to have the opposite effect on restaurants' organization-level spanning, it is difficult to expect concrete patterns in their organization-level spanning. However, as both community-level income and education are expected to positively influence firms’ product-level spanning, many restaurants in these economically affluent and socially educated towns would engage in product-level spanning and offer differentiated menus among the cuisine categories they belong to. For example, restaurant 2941 in Falls Church, VA, diversifies into, and belongs to, the French and American (New) categories while another restaurant Mixing Bowl stays in the Korean category. Still, both restaurants engage in product-level spanning by bringing and fusing elements outside their focal categories and provide hybridized offerings; 2941 provides “modern American French dishes with Mediterranean influences” such as a burger with turkey, feta cheese, cheery peppers, and pita bread and Mixing Bowl offers Korean cuisine with Mexican touch such as kimchi taco with cilantro, making them compound or multi-compound players.

On the other hand, I expect that restaurants in Dunkirk, a city with above-average income level and below-average education level, will tend to offer typical offerings in a single or limited number of culinary styles, being specialists.

Towns with below-average income levels would have more diversified restaurants that engage in organization-level spanning to attract a broader base of consumers. For example, Eddie’s Café in Beltsville, MD, claims to be a Chinese and American restaurant, and Siu's Bistro in Silver Spring, MD, is categorized as a Chinese, Japanese, and Thai 
restaurant. However, restaurants in towns such as Beltsville, where residents’ education level is below average, would tend to be less likely to engage in product hybridization, looking more like mixture organizations. For example, Eddie’s Café offers typical Chinese and typical American food (e.g., chicken lo mein and cheeseburgers). In comparison, restaurants in towns with higher education levels, such as Silver Spring, would actively engage in product-level spanning and provide differentiated products by fusing elements from disparate culinary styles. Siu’s Bistro, for instance, provides sushi rolls with Thai fish sauce in addition to typical Japanese and typical Thai dishes.

In sum, I expect that restaurants in towns such as Beltsville are more likely to be mixture category spanners with a high degree of organization-level spanning and a low degree of product-level spanning, and restaurants in towns such as Silver Spring, McLean, and Falls Church are more likely to be compound organizations that engage in a higher degree of product-level spanning. Restaurants located in towns such as Dunkirk are expected to be category specialists, offering typical products in a claimed culinary style.

\section{Measures}

\section{Dependent variables}

Organization-level spanning: Organization-level spanning is defined as the extent to which an organization has membership in multiple market categories (e.g., Hannan et al. 2007; Rao et al. 2005). The process of identification begins with organizations’ membership (Tajfel and Turner 1986; White 2008). All establishments listed in the restaurant group on Yelp are categorized into one or more of 108 cuisine styles, such as American, French, Korean, and so on (see Table 1). About half of the sample belongs to one cuisine style (56\%), $27 \%$ of the restaurants are in two styles, and the rest belong to 
three or more cuisine styles (17\%). The categorization is made by the restaurants in consultation with the website. These cuisine styles are typically the first information potential consumers see about the restaurants and work as salient market categories used as a classificatory schema in the market (Leclerc, Hsee, and Nunes 2005). In other words, these styles are the actual heuristics that restaurants and (potential) consumers rely on to identify and evaluate the restaurants (Kovács, Carroll, and Lehman 2013; Smith 2011).

\section{INSERT TABLE 1 ABOUT HERE}

Figure 4 is a multidimensional scaling plot of the cuisine styles. Figure 5 enlarges the central part of Figure 4. The nodes in Figure 4 are cuisine styles. The nodes are positioned relative to one another according to their similarity, as determined by the composition of offerings of the underlying restaurants. The cuisine styles are not mutually exclusive (like those used in other industries) — that is, some styles share similar attributes, while others do not. Asian cuisine styles, for example, tend to be positioned on the upper left side of the figure, whereas European cuisine styles appear on the lower right side. Node size is proportional to the amount of heterogeneity among restaurants of a given style. Large nodes thus denote styles with large heterogeneity among the offerings of restaurants; smaller nodes indicate that restaurants are more homogeneous. Figure 4 shows that restaurants in the Korean category, for example, provide more diverse offerings, while those in the Mexican category provide relatively similar offerings.

INSERT FIGURES 4 AND 5 ABOUT HERE 
Because some cuisine styles share more attributes and are considered closer than others (as shown in Figures 4 and 5), I took into account the distance between the categories a restaurant spans when measuring the degree of organization-level spanning following previous research (Kovács and Hannan 2010; Kovács and Johnson 2013).

$$
\text { Org. }- \text { level Spanning }= \begin{cases}0 & \text { if numcate }=1 \\ \text { numcate } * \bar{d} x & \text { if numcate }>1\end{cases}
$$

where numcate denotes the number of categories the organization belongs to and $\bar{d} x$ denotes the average distance between the categories spanned (Leahey et al. 2014; Sohn 2001). The average distance between the categories was calculated using the cosine distance between each pair of categories on a co-occurrence matrix, which shows which categories are claimed together by restaurants. Including cosine distance between categories allowed the similarity structure of the categories spanned to be captured (Sohn 2001). For instance, as the distance between Korean and Japanese is 0.84 , the degree of organization-level spanning of a restaurant that spans these two categories is 1.68 $(=2 * 0.84)$, while the score of a restaurant that spans Korean and Mexican is 1.94 $(=2 * 0.97)$.

Product-level spanning: The second dependent variable is product-level spanning. While I followed previous literature to measure the degree of organization-level spanning using category membership and category distance, I created a novel measure of the degree of product-level spanning by calculating average product typicality of each 
restaurant to its claimed category (or categories). Previous studies have used typicality to measure the degree of category spanning and have shown that typicality to a category decreases as category spanning increases (e.g., Kovács and Johnson 2013; Smith 2011). To establish the product typicality of restaurants, I analyzed every word used in the menus of all the restaurants in the sample and used word-category collocation mapping, a commonly utilized computational linguistics approach. The correspondence analysis of the menu words and the cuisine styles provides face validity to my approach to measure the degree of product-level spanning.

Figure 6 illustrates how typical some words are in Thai, Japanese, and Greek styles. This graph is derived from correspondence analysis, a commonly used method to visualize the associations between the levels of a two-way contingency table (Benzécri 1973; Greenacre 1984). This analysis also follows Kovács and Johnson (2013)’s correspondence analysis of menu words of restaurants in San Francisco. In the figure, the centers of each style are denoted by a triangle, and the distance of words from the style centers is inversely related to their typicality score. Figure 5 shows that some words are close to the Japanese style but not to others, such as sashimi, miso, seaweed, and teriyaki. Some words, such as shrimp and soup, are close to the Thai and Japanese styles but not to the Greek. Finally, words such as salad, spinach, and lemon are equidistant from the three styles, indicating that they are present in all three categories and are not highly distinctive of any of the styles.

INSERT FIGURE 6 ABOUT HERE 
To measure the degree of product-level spanning of a restaurant, I first calculated the typicality of each of the words used in dish names and dish descriptions in each of the 108 categories by computing the Jaccard similarity of the word to the category, following Kovács and Johnson (2013). I excluded all prepositions, conjunctions, and interjections. This left 12,356 unique words in 108 categories. These numbers are comparable to 12,323 unique words in 91 categories, the numbers for the sample of restaurants in San Francisco reported by Kovács and Johnson (2013).

Typicality $\left(\right.$ word $_{i}$, category $\left._{j}\right)=\frac{\#\left(\text { word }_{i} \& \text { category }_{j}\right)}{\#\left(\text { word }_{i}\right)+\#\left(\text { category }_{j}\right)-\#\left(\text { word }_{i} \& \text { category }_{j}\right)}$

where \# $\left(\right.$ word $_{i} \&$ category $\left._{j}\right)$ denotes the number of times the word $i$ appears on menus in category $j$, \#(word $\left.)_{i}\right)$ denotes the total number of times the word $i$ appears on the menus of all restaurants, and \#(category $\left.y_{j}\right)$ denotes the total number of words in category $j$.

Kovács and Johnson (2013) summarize the validity of using Jaccard similarity as a commonly used similarity measure (Batagelj and Bren 1995). First, typicality of a word in a category increases with the number of co-occurrences (i.e., \#( word $_{i} \&$ category $\left.\left._{j}\right)\right)$; second, typicality of a word in a category decreases when the total number of words that appear in the category increases (i.e., \#( category $\left._{j}\right)$ ). These two criteria assure that words that tend to appear in one category have high typicality (e.g., the word bulgogi tends to appear on menus of Korean restaurants). The third property of Jaccard similarity is that typicality of a word in a category decreases with the number of total times the word appears in the whole sample (i.e., \#(word $)$ ). This property suggests that the measure 
discounts words that appear widely on most menus (e.g., chicken).

In the next step, using the word typicality, I calculated dish typicality in each category by taking the average of the word typicality for all words used to describe each dish. Then I chose the highest score among dish typicalities in the claimed categories for each dish and averaged these scores to calculate the average dish typicality of a restaurant. Finally, because typicality and category spanning are inversely related, I subtracted the average dish typicality of a restaurant from 1 to get a degree of product-level spanning for a restaurant. Because the values of product-level spanning are low in absolute number, I rescaled the values so that the maximum observed value of product-level spanning is 1 and the minimum is 0 for better interpretability (Kovács and Johnson 2013). Note that as such a multiplicative rescaling changes only the unit of measurement. See Appendix 1 for a detailed illustration of how product-level spanning is calculated.

\section{Product-level spanning of an organization = 1 - Average of the highest dish typicality in the claimed categories}

For example, imagine two restaurants $\mathrm{A}$ and $\mathrm{B}$, both claiming membership in two categories, Italian and Mexican. This example is purely imaginative to demonstrate how the measure works. Restaurant A does not engage in much product-level spanning and offers two dishes, a typical Italian dish and a typical Mexican dish. The typicality score of the Italian dish will be high (let's say it’s 0.9) in the Italian category and low (0.1) in the Mexican category. On the other hand, the typicality score of the Mexican dish will be 
low (0.1) in the Italian category and high (0.9) in the Mexican category. The overall product-level spanning score for Restaurant A is $0.1(=1-(0.9+0.9) / 2)$. In contrast, Restaurant B actively engages in product-level spanning and offers two fusion dishes. Thus, the dishes are atypical in both the Italian (0.1) and Mexican (0.1) categories, and typicality scores will be low in both. Because the highest typicality score is taken and it is 0.1 in this case, the overall product-level spanning score for Restaurant B is 0.9 (= 1$(0.1+0.1) / 2)$

\section{Independent variables}

The first independent variable is the community income level. It is measured as five-year estimates of median household income, in tens of thousands of dollars, of each city between 2008 and 2012, taken from the American Community Survey conducted by

the U.S. Census Bureau. Second, the degree of education is measured as the proportion of people in a city aged over 25 who have at least a bachelor's degree, averaged across 2008 through 2012. In an additional set of analysis to investigate the effect of the degree of education, I split the proportion of the people with at least a bachelor's degree into those with a bachelor's, master's, and Ph.D. degree, respectively.

\section{Control variables}

A number of control variables are included for analysis. At the organizational level, I controlled for the price level of restaurants. Yelp uses four categories to classify the price level of a restaurant, indicating "the approximate cost per person for a meal, including one drink, tax, and tips”5: \$ denotes “under US\$10,” \$ denotes “US\$11US\$30,” \$\$ denotes “US\$30-US\$61,” and \$\$\$ denotes “above US\$61.” In my sample,

\footnotetext{
${ }^{5}$ From yelp.com
} 
$43 \%$ of the restaurants are in the lowest price range, $51 \%$ are in the $\$ \$$ range, $5 \%$ are in the $\$ \$ \$$ range, and the remaining $1 \%$ are in the $\$ \$ \$$ range. To allow for the nonlinear effect of price, I included dummy variables for all levels of the price rating except \$, which was used as a baseline. I also included a dummy variable for restaurant chains to see if chains are more or less likely to engage in category spanning. In addition, I included a dummy variable for fast food restaurants to account for their unique business style. According to Block, Scribner, and De Salvo (2004) and Sloane, Lewis, and Nascimento (2005), chain and fast food restaurants are more likely to be located in poorer neighborhoods and tend to offer category-typical products. The age of the restaurant is also included, which I measured with the number of years since the first review of the restaurant (Kovács and Johnson 2013). Next, one important assumption of this study is that consumers for restaurants in a town are residents of that town. Previous literature has argued that customers of restaurants tend to be local residents (Meltzer and Schuetz 2012). There, however, may also be other parts of the clientele, such as commuters. To control for this issue, I included dummy variables for restaurants that were closed before 7 p.m. or on Sundays, based on the presumption that the main customer base for these restaurants is not local residents but commuters from other towns ${ }^{6}$. Finally, to control for category-specific effects, I included dummy variables for the categories the restaurant is in (107 dummies except Austrian, which was used as a baseline).

At the city level, the ethnic diversity of the town is included because it may influence demand for each cuisine style and for spanning. It is calculated as the Blau index of races in each town (Blau 1977). Income diversity and education diversity of the

\footnotetext{
${ }^{6}$ In addition to these dummy variables, I included several more control variables at the city-level to address this issue, which are described in the next paragraph.
} 
town are also included, measured using the Blau index. As mentioned earlier, an important assumption of this study is that consumers for restaurants in a town are residents of that town. In addition to including dummy variables for restaurants that were closed before 7pm and on Sundays, I added two more control variables. Due to the central location of Washington, DC, in the metropolitan area, its restaurants serve a large number of commuters and tourists as well as residents. Thus, to control for its specificity, I included a dummy variable for Washington, DC. By the same token, I also included a dummy variable for central counties, as designated by the Census Bureau. ${ }^{7}$ I included the population density (thousand people/square mile) and the total number of restaurants in the town to control for the effect of overall demand and industry competition in the region. Next, the proportion of the population aged 20-29 in a city is controlled for based on the previous findings that young adults tend to show highly risk-taking behaviors and openness to novelty, which may influence firms' likelihood of engaging in both levels of spanning. Finally, I included median housing rent of the city as a proxy for overhead costs of restaurants in the focal town. Descriptive statistics and correlations for the variables are provided in Table 2.

\section{INSERT TABLE 2 ABOUT HERE}

\section{Analysis}

I tested my hypotheses using the generalized linear model (GLM) framework

\footnotetext{
${ }^{7}$ According to the Census Bureau, central counties in metropolitan statistical areas are defined as counties that (a) have at least 50 percent of their population in urban areas (urbanized areas or urban clusters) of at least 10,000 population or (b) have within their boundaries a population of at least 5,000 located in a single urban area (urbanized area or urban cluster) of at least 10,000 population (http://www.census.gov/population/metro/files/00-32997.txt).
} 
(McCullagh and Nelder 1989). ${ }^{8}$ The two dependent variables are nonnegative outcomes. The first dependent variable, organization-level spanning, has many zero values. To account for the skewedness of the variables, I used the GLM model with a log link (Hardin and Hilbe 2012). The second dependent variable, product-level spanning, has a minimum value of 0 and a maximum value of 1 . I applied the fractional logit model (Papke and Wooldridge 1996) using a GLM with a binomial distribution and a logit link function. I estimated both models using robust standard errors and cluster observations by city to account for possible heterogeneity among cities that is not explained by the citylevel control variables in the models.

\section{Results}

Figure 7 is a scatterplot of the organization- and product-level spanning of the sample. As expected, there is a variance in product-level spanning for a given degree of organization-level spanning. For example, Noodles \& Company had one of the highest degrees of organization-level spanning (4.19) diversifying into seven cuisine styles, but it had a low product-level spanning score (0.36), implying that Noodles \& Company is more of a mixture organization that provides category-typical offerings from various market domains. In comparison, Teaism, which diversified into six cuisine styles, had a similar degree of organization-level spanning (4.92), but its product-level spanning score

\footnotetext{
${ }^{8}$ Many empirical studies using skewed nonnegative outcomes have made use of a Tobit model, which combines the probit likelihood that a zero value will be observed with the linear regression likelihood to explain nonzero values. The Tobit approach certainly improves on standard linear regression by taking account of the mass point at zero. However, some researchers (e.g., Papke and Wooldridge 1996) have argued that as the Tobit model is a censored regression technique, it is not applicable where values beyond the censoring point are infeasible. The motivation for Tobit is often that of an underlying latent variable, but the latent variable interpretation is difficult to motivate in the current setting. GLM is a more appropriate approach in this case. See Harding and Hilbe (2012) for more information.
} 
was 0.87 , implying that Teaism is more of a compound organization that provides crossbred offerings. Figures 8 and 9 show part of the menus of these two restaurants.

\section{INSERT FIGURES 7, 8 AND 9 ABOUT HERE}

Table 3 shows the results of the regression models predicting firms' organizationlevel spanning. In Model 1, only control variables are included. As expected, chain and fast food restaurants are less likely to engage in organization-level spanning and stay as category specialists. Price is found to have nonlinear effects on organization-level spanning. While restaurants with the highest price level (Price=“\$\$”) most actively engage in spanning, the degree of organization-level spanning of restaurants with the cheapest price level (Price=”\$) is not statistically different from that with the price level of “\$\$”. This trend continues in the full model (Model 4), where both independent variables are included. In the full model, total number of organizations had a negative and significant effect on organization-level spanning $(b=-0.0253$, $p<0.01)$, implying that heightened competition leads organizations to specialize in a narrow niche. Median rent became significant and positive in the full model as well ( $\mathrm{b}=0.1165, \mathrm{p}<0.10$ ), implying that high overhead cost motivates restaurants to diversify into multiple market domains to attract a broader base of consumer groups.

INSERT TABLE 3 ABOUT HERE 
Model 2 introduces the first independent variable, the median household income of each town; Model 3 adds the second independent variable, the education level. Model 4 includes both independent variables. In Model 4, the coefficient of income is negative and strongly significant at the $0.1 \%$ level $(b=-0.0691$, se $=0.015$, one-tailed test $)$ and the coefficient of education is positive and significant at the $0.1 \%$ level as well $(b=0.7979$, $\mathrm{se}=0.148)$, supporting Hypotheses 1 and 2, respectively.

Figure 10 visually demonstrates the magnitude change of the contrasting effect of income and education on organization-level spanning derived from Model 4. The results postestimation margins analysis using the full model implies 64.5 percentage decrease in the predicted mean of organization-level spanning, from 0.87 to 0.31 , if median household income rises from $\$ 50,000$ to $\$ 250,000$. In comparison, the model indicates that the predicted mean of organization-level spanning will increase by about 61.4 percent, from 0.51 to 0.76 , if the proportion of people with a bachelor's degree or higher to the total population older than 25 rises from 0.2 to 0.8 .

\section{INSERT FIGURE 10 ABOUT HERE}

As an additional analysis and robustness check, I split the level of education by including the proportion of bachelor's, master’s, and PhD degree holders, separately, instead of the aggregated proportion of the degree holders. In Model 6, the coefficients of only Master's and PhD variables are positive and significant at the $5 \%$ and the $1 \%$ level, respectively ( $b=1.0143,2.0267$; se $=0.323,0.431$, respectively), while the coefficient of income remains negative and significant. In sum, the results suggest the contrasting effect 
of local communities' economic status and social status on firms' organization-level spanning. Model 7 and 8 in Table 4 were run for additional robustness checks with 1,538 restaurants located in Washington, DC, omitted for analyses. In both models, the coefficient of income was negative and significant $(\mathrm{b}=-0.0639, \mathrm{p}<0.001$; $\mathrm{b}=-0.0372$, $\mathrm{p}<0.05$, respectively). Also, the coefficient of education was positive $(\mathrm{b}=0.8219)$ and significant at the $0.01 \%$ level in Model 7 and those of Master's and $\mathrm{PhD}$ variables were positive and significant at the $1 \%$ level ( $\mathrm{b}=1.1805,1.7853$, respectively) in Model 8. These results support my argument that although the two constructs tend to be positively associated with each other, the mechanisms and the directions by which income and education influence firms' organization-level spanning may be different. Economic affluence enhances market potential and stability, which in turn enables firms to concentrate on a narrow market niche, whereas higher education leads social elites to be cultural omnivores who have inclusive tastes, leading them to appreciate and better understand firms that diversify into multiple businesses.

\section{INSERT TABLE 4 ABOUT HERE}

Table 5 reports the findings of the regression models predicting firms' productlevel spanning. The coefficient of income was insignificant in the partial model (Model 13) and became significant and negative in the full model (Model 15, $b=-0.0297, p<0.10$ ). Multicollinearity may be a reason for the lack of significance because income and 
education are highly correlated to each other ${ }^{9}$. But the clustered robust standard errors of the coefficient of income do not change much between Model 13 and Model 15 (se $=0.011$ and 0.016 , respectively), implying that we cannot reject the null hypothesis that income is not a significant factor that increases product-level spanning.

\section{INSERT TABLE 5 ABOUT HERE}

In comparison, education stays significant across all models. In a partial model without income (Model 14), the coefficient of education is positive and significant at the $10 \%$ level $(b=0.2222$, se $=0.148$ ). It became more significant in Model 15 , at the $5 \%$ level (b=0.4362, $\mathrm{p}=0.197$ ), supporting Hypothesis 4. This result supports my argument that highly educated consumer groups are more likely to appreciate and better understand hybridized, novel offerings. The full model indicates that the predicted mean of productlevel spanning will increase by 8.4 percent if the proportion of people with a bachelor's degree or higher in the population older than 25 rises from 0.2 to 0.8 . This effect is visually demonstrated in Figure 11.

\section{INSERT FIGURE 11 ABOUT HERE}

As an additional and more elaborate analysis, I split the level of education by including the proportion of bachelor's, master's, and $\mathrm{PhD}$ degree holders, separately, instead of the aggregated proportion of the degree holders. In the full model with the

${ }^{9}$ VIF scores of the two variables from an OLS regression are 10.99 for income and 6.08 for education. 
alternative dependent variables for education (Model 17), the coefficient of income continues to be insignificant, failing to support Hypothesis 3. On the other hand, both in the partial and the full model (Model 16, 17), the coefficient of only the PhD variable continues to be positive and significant ( $b=1.6201,1.5597$, respectively, $p<0.05$ ), supporting Hypothesis 4. This trend stays consistent in the analysis for additional robustness checks without restaurants located in Washington, DC (Model 18 and 19 in Table 6).

INSERT TABLE 6 ABOUT HERE

Several control variables are worth noting. First, as expected, the coefficient estimates of chain restaurants and fast food restaurants are negative and strongly significant in all of the models. This suggests that chain and fast food restaurants are less likely to engage in product-level and organization-level spanning, implying that they offer more category-typical products in a given cuisine style with standardized processes and menus (Carroll and Torfason 2011). Next, the total number of restaurants in a given community has positive and significant effect on restaurants’ product-level spanning. This result suggests that increased competition creates pressure for restaurants to differentiate themselves to stand out from a number of competitors.

Third, restaurants with the highest price level (\$\$\$, above $\$ 61$ for a meal/person) are the ones that engage most in product-level spanning. This result is consistent with the findings of previous literature that high-status producers, who often charge high prices, create and introduce novel offerings to the field by fusing disparate elements together 
(Rao et al. 2005). But results also suggest that product-level spanning is not always driven by the high-status producers who charge higher prices. Across all models, restaurants that provide the cheapest offerings (i.e., \$, below \$10) are more likely to engage in product hybridization than those who provide moderately priced offerings (i.e., \$, \$11-\$30). This result implies that product-level spanning can occur at relatively low cost and does not necessarily entail targeting only a limited group of wealthy consumers. This finding also supports the result of the main effect in that adopters of innovations are active cultural omnivores who prefer hybridized offerings regardless of their wealth status. In addition, even after controlling for the price levels, the effect of communitylevel demand characteristics such as education continues to be significant, suggesting that the demand side can pull product hybridization and encourage firms to engage in product-level spanning.

\section{Discussion}

The result of the analysis of the restaurant industry generally supports my hypotheses on the community-level antecedents of firms' organization-level spanning. It suggests the contrasting effect of consumers' economic and social status on firms’ organization-level spanning. Although the two constructs tend to be positively associated with each other, their independent effects are found to be driven in opposite directions. The result implies that while economic affluence enhances market potential and stability, which enables firms to devote their resources to a narrow market niche, higher education leads social elites to be cultural omnivores who have inclusive tastes and higher tolerance for firms that operate in multiple business domains. 
With regard to product-level spanning, only education has a positive effect and remains significant across all models. While both wealthy and educated individuals are generally regarded as trendsetters who drive fashion and contribute to the emergence of new organizational forms (Bourdieu 1984; Simmel 1957), I suggest different mechanisms by which the two constructs influence firms' product-level spanning: economic affluence makes the relative cost of exploring novel offerings smaller, whereas higher education influences individuals' preference for hybridized offerings. The significant effect of only the education variable implies that preference has a stronger influence than economic condition on individuals' decision-making on exploration.

A possible alternative explanation for the insignificant effect of income on product-level spanning is related to a scope condition of this study on functional versus nonfunctional consumption. When a new offering is created as a result of product-level spanning, the hybridized offering may retain the original properties and functions of its imported elements (i.e., element aggregation) or transform into a totally new product with different functions and utilities (i.e., element fusion). While hybrid offerings may often contain both original and new properties to different extents, the aggregator type of products can appeal to lower-income individuals because they may reduce overall cost (killing two birds with one stone!). I developed my argument focusing on the novelty of the hybridized products because even the aggregator type of hybridized products can provide hedonic value to rich trendsetters due to the newness they bring to the market by collecting disparate functions into one offering (as when the iPhone was introduced), while this newness may be translated as unfamiliarity and uncertainty by budgetconstrained consumers. But because the multifunctionality of these products can attract 
budget-constrained consumers as well as rich trendsetters, Hypothesis 3 would work stronger in a context of nonfunctional consumption that particularly emphasizes novelty of products.

The results of the study would add a distinctive sociological voice to research on firms' location strategies by explicating differential and nuanced effects of the economic and social status of local communities on organizations' incentives to span categories. While consumers’ economic status and social status are highly correlated with each other, I found that economic status has a negative relationship with firms’ organization-level spanning, whereas social status has a positive relationship with firms’ organization- and product-level spanning. Organizations, thus, should consider how their business scope and product portfolio are aligned with the communities they are, or plan to be, located in. 


\section{CHAPTER 5.}

\section{Study 2: Category Population and Firms’ Spanning}

A wide array of literature on management, industrial organizations economics, and strategic groups has emphasized the importance of competitors on firms' strategy and performance (e.g., Caves and Porter 1977; McGee and Thomas 1986; Porac et al. 1999). Indeed, the analysis of competitors' action has been a central focus of research that takes outward-looking perspectives including industrial organizations economics, neoinstitutionalism, and organizational ecology. While Study 1 investigated local demand characteristics, which have received relatively little attention in the previous literature, as important antecedents of firms' spanning, local demand is certainly not the only external factor that would affect firms’ spanning activities. Considering competitors would be a necessary and important step to draw a more complete understanding of the influence of various community-level constituencies on firms’ spanning activities.

Scholars on neoinstitutionalism and organizational ecology have long argued that

the number of organizations matters for a firm in formulating its strategies and success. It influences the intensity of competition and the amount of resources available to organizations (Baum and Singh 1996). Also, it affects the institutional legitimacy of the population, which also enhances the capacity of the organizations to acquire resources as 
well as imposing institutional pressures on them (Aldrich and Fiol 1994; DiMaggio and Powell 1983; Hannan and Carroll 1992; Meyer and Rowan 1977).

Category population has been a major research topic by organizational ecologists since Hannan and Freeman’s early work (1989). They have developed a densitydependence model and investigated organizational founding and failure rates as a function of population density (Hannan and Freeman 1989; Hannan and Carroll 1992). While the density dependence model of the founding and failure rates has received substantial empirical support in a variety of contexts and has strong implications on the population-level dynamics and the birth and the death of organizations (see Baum and Shipilov 2006 for a review), its implications can go beyond organizational founding and failure (Boeker 1991; Haveman 1993). Since institutional and competitive pressures driven by population density influence incumbents as well as new entrants, the insight may also be applied to the studies of change in incumbent organizations, specifically to category spanning that deals with organizational boundaries and their product features. As such, in this chapter, I extend past ecological research by focusing on organizational strategy, rather than organizational births and deaths, and by incorporating the confluence of literature on strategic management, organizational ecology, and neoinstitutionalism and investigate how category population influences organizations to adjust their categorical membership and product properties.

\section{Theory and Hypotheses}

The number of organizations in the same market category is important for firms' survival and performance, at least, for two reasons. First, it influences the intensity of 
competition. The intensity of competition is largely a function of the number of organizations with similar resource requirements (McPherson 1983; Porter 1980). Since patterns of resource use tend to be specialized to each market segment, the presence of organizations in the given market category increases the degree of direct competition (Baum and Singh 1994). Second, according to the neoinstitutional (DiMaggio and Powell 1983; Meyer and Rowan 1977; Zucker 1977) and organizational ecology (Aldrich and Fiol 1994; Hannan and Carroll 1992) literature, population density—i.e. the number of organizations — affects cognitive and sociopolitical legitimacy of the group—how a given category is considered taken-for-granted. From a cognitive legitimacy perspective, an organizational form is legitimated and considered taken-for-granted "when there is little question in the minds of actors that it serves as the natural way to effect some kind of collective action” (Hannan and Carroll 1992, 34). A more sociopolitical legitimacy perspective, in comparison, "emphasizes how embeddedness in relational and normative contexts influences an organizational form's legitimacy by signaling its conformity to social and institutional expectations” (Baum and Shipilov 2006, 88). These two facets of legitimation are viewed complementary and fundamentally interrelated and the population density is known to facilitate the legitimation of its form by these processes.

Using the argument of competitive and institutional pressures, organizational ecologists have developed the density-dependence model. They especially studied organizational founding and failure rates as a function of category population and suggest curvilinear relationships (Hannan and Freeman 1989; Hannan and Carroll 1992). According to the density-dependence explanations, initial increases in population enhance the institutional legitimacy of the population and the capacity of a population's 
members to acquire resources-e.g. consumers' attention and contribution-increases greatly when those controlling resources take the organizational form for granted. However, as a population gets too big, the nature of interdependence among a population's members becomes competitive. When there are few organizations in a given category, competition with others for scarce common resources can easily be avoided. However, as the number of potential competitors grows, avoidance becomes more difficult. Combined, the mutualistic effects of initial increases in category population and the competitive effects of further increase suggest curvilinear effects of population density on founding and failure rates of organizations. While the density dependence model of the founding and failure rates has received substantial empirical support in a variety of contexts including newspapers, breweries, insurance companies, and banks (Hannan and Carroll 1992), it has implications beyond organizational founding and failure. It may also be applied to the studies of strategic choices of incumbent organizations, specifically to diversification and entry into new product-consumer markets (Boeker 1991; Haveman 1993). Haveman (1993) argues that "the decision of an existing firm to enter a new domain is similar to the decision of an entrepreneur to found a new venture” (p. 594) since institutional and competitive pressures driven by population density would also apply to incumbents and influence their performance. By the similar token, category population will provide firms with institutional and competitive pressures and opportunities for engaging in spanning behavior. Focusing on this point, I investigate how the category population influences organizations to adjust their categorical membership and product properties and engage in two levels of spanning. 


\section{Category population and organization-level spanning}

When a category first emerges by a few dedicated pioneers, it is sparsely populated with few organizations and lacks institutional legitimacy (Hannan and Carroll 1992; Suarez, Grodal, and Gotsopoulos 2015). It is seldom well defined and great uncertainty exists "with regard to the meaning, boundaries, and even the very existence" of the market itself (Suarez et al. 2015, 438; see also Aldrich and Fiol 1994; Lounsbury, Ventresca, and Hirsch 2003; and Santos and Eisenhardt 2009). Legitimacy increases with density at a decreasing rate and especially at low levels of density, growth in numbers primarily serves to legitimate a given market category. Once the number of organizations begins to rise, the category gains traction, its boundaries become better defined, and the capacity of organizations to acquire resources increases greatly. The category is now deemed taken-for-granted and considered legitimate and the demand for the category increases accordingly (Hannan et al. 2007). With the increased legitimacy and demand and reduced uncertainty of the category, many organizations conducting business outside the category would enter and diversify into the focal category to exploit the opportunities and full market potential provided by the legitimated category (Haveman 1993).

When a population continues to grow in the category, however, growth potential of organizations becomes limited. First, the legitimating effect of density levels off. As addressed earlier, density has a powerful effect on the legitimacy of the category especially in the early stage with few organizations. But once the category is considered taken for granted, legitimacy becomes relatively stable and density plays a less important role in determining the extent to which a category is viewed as legitimate (Hannan 1997). On the other hand, continued growth in the number of organizations 
aggravates competition. Competition with others for scarce common resources is intensified and the need for firms to concentrate their capacities on a focal market category increases to effectively appeal to the audience in the category (Hannan and Freeman 1992). Accordingly, incumbent organizations would become more focused players in a market with numerous competitors. Combined, I predict an inverted Ushaped relationship between the category population and organizational-level spanning.

Hypothesis 5: There will be an inverted U-shaped association between the number of organizations in the same market category and firms' organizationallevel spanning.

\section{Category population and product-level spanning}

How would competitive and institutional pressures led by the category population influence the way organizations construct their product offerings? A category is not well defined and the meaning of the category and its elements are fuzzy and being negotiated when there are only few organizations (Granqvist, Grodal, and Wolley, 2013). Consumer demand as well as their understanding of the category thus remains fluid, too (Clark 1985; Kennedy 2008). Facing this uncertainty, organizations diverge on their offerings based on basic technological differences among products or differences in how they understand the new category and its products (Kaplan and Tripsas 2008; Rao 2008). Later, once the category becomes established and more organizations populate the category, "shared understandings about the category grow to allow the stakeholders to make better sense of the products that best serve their needs” (Suarez et al. 2015, 444). Clear categorical expectation for the member organizations is established and it helps to clarify the 
associations among product characteristics and the category. This categorical expectation dictates the characteristics that products should possess to claim membership in a category and the pressure for the organizations to offer category-typical products grows. Products that deviate from the categorical expectation may be penalized in the market for their lack of conformity (Hannan et al. 2007; Leung and Sharkey 2014; Zuckerman 1999). The study of the "minivan" category by Porac and colleagues (2001) demonstrates the converging expectation about product properties. They showed that in the early phases of the category, firms introduced a wide array of different product designs but as certain technological characteristics (e.g., front-wheel drive, sliding doors, seven passengers, see Rosa et al. 1999) gained more favor than others, new members as well as incumbent firms followed the dominant design (Abernathy and Utterback 1978; Anderson and Tushman 1990; Klepper 1997).

However, as a population continues to grow, the nature of interdependence among organizations becomes competitive. When there are few organizations, competition with others for scare common resources can easily be avoided. But as the number of potential competitors grows, avoidance becomes more difficult. Organizations’ pressure to be seen and standout increases and, accordingly, their need to differentiate their products from numerous other competitors would rise in turn. Thus, they will be more likely to engage in product-level spanning and provide novel offerings that incorporate new elements from outside their main domain (Vinokurova 2015). Therefore, I propose the following curvilinear effect: 
Hypothesis 6: There will be a U-shaped association between the number of organizations in the same market category and firms' product-level spanning.

\section{Methods}

\section{Sample and data}

I test the hypotheses with the same sample and dataset I use for Study 1. Because the dependent variables of the two studies are the same, I run an empirical test together in the same models.

\section{Measures}

The dependent variables of Study 2, organization- and product-level spanning, are the same with those of Study 1. The independent variable of Study 2 is category population. It is measured as the number of restaurants in a category in a city that a given restaurant claims membership to. If the restaurant claims membership in two or more categories, the category with the greatest number of restaurants is selected to measure the variable. The data are collected from Yelp. Category population varies by category and city. For example, there is only one restaurant in French category in Rockville, Maryland, while the number in Alexandria, Virginia, is 10. The population in Pizza category, in comparison, in Rockville is 26 and 75 in Alexandria. All the control variables used in Study 1 are included for the analysis.

\section{Analysis}

Like in Study 1, I tested the hypotheses using the generalized linear model (GLM) framework (McCullagh and Nelder 1989). The two dependent variables are nonnegative 
outcomes. The first dependent variable, organization-level spanning, has many zero values. To account for the skewedness of the variables, I used the GLM model with a log link (Hardin and Hilbe 2012). The second dependent variable, product-level spanning, has a minimum value of 0 and a maximum value of 1 . I applied the fractional logit model (Papke and Wooldridge 1996) using a GLM with a binomial distribution and a logit link function. I estimated both models using robust standard errors and cluster observations by city to account for possible heterogeneity among cities that is not explained by the citylevel control variables in the models.

\section{Results}

Table 7 shows the result of regression models predicting organizational-level spanning. Model 23 is identical with Model 1 from Table 3 to use as a baseline. The category population and its squared term are added in Model 25 to test the curvilinear effect of category population. According to Hypothesis 5, which predicts an inverted Ushaped relationship, we should find a negative coefficient estimate on the squared term with a positive coefficient estimate on the category population. As expected, organization-level spanning appears to follow an inverted U shape, with a negative coefficient on the square term $(b=-0.1198, p<0.001)$ and a positive coefficient estimated on the category population variable ( $b=0.3074, \mathrm{p}<0.01$ ), as category population grows. This trend continues in the full model that includes the two explanatory variables of Study 1 (Model 26) and both coefficients remain significant at the $1 \%$ and the $0.1 \%$ level, respectively ( $b=-0.1175$, for the squared term; $b=0.2993$ for the linear term). Also in 
Model 27, where split education variables are included in place of the original education variable, the coefficients of the squared and the linear terms stay strongly significant in the expected directions ${ }^{10}$.

\section{INSERT TABLE 7 ABOUT HERE}

Figure 12 illustrates the inverted-U relationship between the category population and organizational-level spanning using the estimates from Model 26. The expected organizational-level spanning score is 0.70 , in the full model, when the category population is 50 and all the other explanatory variables remain at their means. This value increases by $6.64 \%$ to 0.74 when the population goes up to 150 , and it falls again by $15.7 \%$ to 0.63 when the population reaches 250 . This result supports my argument that firms in other market categories diversify into the given market category once the category secures legitimacy and draw more demand with less uncertainty, but when competition gets too intensified due to the influx of too many firms, they narrow down their scope and become specialists to effectively appeal to the focal market demand.

The control variables whose coefficients were significant in Study 1 continue to be significant in Study 2 as well. For example, chain and fast food restaurants were negatively associated with organization-level spanning $(\mathrm{p}<0.001)$ and price had a nonlinear relationship with organization-level spanning across all models (Models 23-27). In the full models (Models 26 and 27), the total number of restaurants in a focal town had a negative and significant relationship with organization-level spanning, implying that

\footnotetext{
${ }^{10}$ The coefficients of income and education variables remain consistent in Models 26 and 27 with the addition of the new explanatory variables in Study 2.
} 
intensified competition arising from a large number of organizations prevents them from spanning market boundaries and forces them to stay focused.

\section{INSERT FIGURE 12 ABOUT HERE}

Next, Table 8 shows results of regressions predicting product-level spanning. Model 28 is identical with Model 12 from Table 5 to use as a baseline. The category population and its squared term are added in Model 30 to test the curvilinear effect of category population. Hypothesis 6 predicts that the category population will have Ushaped curvilinear effect on firms’ product-level spanning. Consistent with the expectation, organization-level spanning appears to follow a U shape, with a positive coefficient on the square term $(b=0.1248, p<0.001)$ and a negative coefficient on the linear term $(b=-0.5359, \mathrm{p}<0.001)$. And both coefficients remain strongly significant at the $0.1 \%$ level in the full models that includes the other explanatory variables in Study 1 (Models 31 and 32).

\section{INSERT TABLE 8 ABOUT HERE}

Figure 13 visually illustrates the curvilinear relationship between the category population and product-level spanning estimated from Model 31. The U-shaped effect implies that firms adjust their product properties in response to the increase in the category population. For example, the expected product-level spanning score is 0.647 when the category population is 50 and all the other explanatory variables remain at their 
means. The score falls by $9.33 \%$ to 0.586 when the population goes up to 150 , and it rises again by $1.47 \%$ to 0.595 when the population reaches 300 . This result supports my argument that a pressure to conform to categorical expectation is greatest when there is a modest number of organizations in a market category. When there are a small number of organizations, clear categorical expectation is not established. On the other hand, when numerous organizations populate the category, intensified competition pressures the organizations to differentiate their product features from those of others to stand out, which leads them to engage in product-level spanning.

\section{INSERT FIGURE 13 ABOUT HERE}

The control variables whose coefficients were significant in Study 1 continue to be significant in Study 2 as well. For example, chain and fast food restaurants were negatively associated with product-level spanning $(\mathrm{p}<0.001)$ and price had a nonlinear relationship with product-level spanning across all models (Models 28-32). Restaurants that were closed before dinner time were more likely to engage in product-level spanning $(p<0.001)$. Also, the total number of restaurants in a focal town had a positive and significant relationship with product-level spanning, implying that intensified competition arising from a large number of organizations gives firms pressure to deviate from category expectation and differentiate their product features by engaging in productlevel spanning. 


\section{Robustness check}

Like in Study 1, I ran additional analyses using the subsample without restaurants located in Washington, DC (Models 9-11 in Table 4, Models 20-22 in Table 6). Results from 4,532 restaurants demonstrate consistent patterns with those from the main analyses. The curvilinear relationships between category population and firms’ category spanning remain significant in the expected directions while the coefficients of the most of the control variables also continue to be consistent with those of the original models.

\section{Discussion}

The results strongly support Hypotheses 5 and 6 about the curvilinear relationships between category population and firms' business boundaries and their product-level spanning. First, the inverted-U relation between category population and organization-level spanning supports Hypothesis 5; a few organizations that first enter a given category are pioneers who contribute to the emergence of the category. Success of the devoted and focused pioneers would enhance legitimacy of the category and this growing legitimacy attracts dabblers, diversified players who attempt to exploit the opportunities in the category (Haveman 1993). However, since they cannot achieve competitive advantages over the focused players (Hannan and Freeman 1977), the category spanners would eventually narrow down their scope and new entrants would also imitate the successful pioneers (DiMaggio and Powell 1983) and become a specialist to stay competitive in the populated market. Consistent with this idea, Haveman (1993) finds an inverted U- shaped relationship between the number of firms operating in a market and entry into that market. According to her, at low levels of market density, 
success of several players in a market leads organizations outside the market to follow them and diversify into the focal market. However, at high levels of market density, competition will swamp its legitimating effect, thereby suppressing entry of organizations into the market.

Next, the U-shaped effect of category population on product-level spanning was found significant across all of the models. This result implies that, while institutional pressures to conform to categorical expectations increase at the early maturing stage of the category, firms attempt to differentiate themselves by engaging in product-level spanning to avoid competitive pressures arising from high population density. Findings from recent studies are consistent with this argument in that organizations create innovative products while staying in an existing category and not claiming a new category. This behavior of fitting new products into an existing category is understood as a way to use innovation as a differentiation strategy within the existing category (Vinokurova 2015). By introducing novel products to the audience of the existing category, organizations would be able to acquire an advantageous position in the field of fierce competition.

While the results demonstrate strong curvilinear relationships between category population and firms’ spanning activities, cautions should be made to draw causal inferences from the results as cross-sectional data of the industry were used to analyze the associations. Constructing panel datasets with longitudinal information would help clarify the causality and strengthen the robustness of analysis. 


\section{CHAPTER 6.}

\section{Conclusion}

\section{Summary and Limitations}

My dissertation has examined community-level antecedents of firms’ market diversification and product differentiation strategies using the concept of category spanning. Exploiting novel and extensive data on the restaurant industry in a large metropolitan statistical area, I found in Study 1 a contrasting effect of economic and social status of consumer communities on firms' market diversification. Results showed a negative effect of residents’ income levels and a positive effect of their education levels on the business scope of the restaurants in a focal town, both effects notable by statistical significance and size. Also, results from a computational text analysis of every word used in the menus of the sample restaurants suggest that it is educated social elites, culturally omnivorous and seeking novelty, who encourage firms to engage in product hybridization. In Study 2, category population is found to have curvilinear relationships with firms’ category spanning. Category population had an inverted U-shaped effect on firms’ organization-level spanning and a U-shaped effect on firms’ product-level spanning. 
While the results of the studies generally supported the hypotheses, my approach and analysis are not without several notable limitations. First, it remains to be seen if the findings are generalizable to other industries. While I believe that the findings from Study 2, which examines the effect of category population on firms' spanning activities, are readily generalizable to any industry where multiple organizations compete in the market to create competitive advantages, findings from Study 1, which concerns local demand characteristics, would be generalizable to at least retail industries, where consumers with different economic and social status directly interact with firms. Additional analyses of other industries would help confirm or find boundary conditions of the results of the present studies.

Next, the dissertation has investigated a single industry, the restaurant industry. Thus, organization-level spanning is examined only as within-industry diversification rather than across-industry diversification. While the mechanisms by which the community-level demand and competition side antecedents influence organization-level spanning are expected to be applied in the case of across-industry diversification as well, further empirical analyses should be accompanied to extend and confirm the validity of the mechanisms.

A third limitation relates to the study sample. I used a large cross-sectional data of the restaurant industry in the Greater Washington, DC, Metropolitan Statistical Area. The sample covers entire organizations in the industry with detailed information about their product features, enabling to analyze the effect of difference in each community on restaurants' category spanning in two different levels. However, collecting panel data 
with a longer time span would strengthen the robustness of analysis and help better explicate causality among the constructs.

\section{Expected Contributions and Future Directions}

\section{Importance of community-level antecedents}

Notwithstanding these limitations, I believe that the current studies make several contributions to the literature on firm strategy, category spanning and firm boundaries. First, despite an upsurge in research on category spanning, few attempts have been made to understand under what external conditions firms are more or less likely to engage in spanning activities (Popielarz and Neal 2007). My dissertation attempts to address the question of why firms span market boundaries and identifies community-level antecedents of firms’ category spanning. While dominant perspectives of strategic management have provided useful insight as to when firms should span market categories, their contribution is focused on the internal structure of the organizations and managerial discretion as main determinants of spanning activities. This dissertation attempts to complement the internal focus by turning attention to external factors, especially at the level of the community in which the organizations inhabit (Adner and Zemsky 2006; Priem 2007; Zander and Zander 2005). Results of the two studies show that organizations' incentives to span categories differ depending on the economic and social status of consumer communities and the competitive landscape of a given market category. Study 1 suggests that consumers' objective economic conditions and subjective preferences and perceptions of categorical boundaries are largely shaped by their economic and social status, and this heterogeneity provides different organizational opportunities and constraints for firms' category spanning. I found that the economic status of consumers 
had a negative relationship with firms’ market boundaries whereas the social status of consumers had a positive relationship with firms' market boundaries as well as productlevel spanning. This finding is intriguing and needs more attention especially considering that the economic and the social status of consumers have a high correlation and often treated together as a single combined concept such as socioeconomic status (SES) in many academic domains (e.g. Bradley and Corwyn 2002; Williams and Collins 1995). In study 2, I found that the category population had a curvilinear effect on organizationallevel (inverted U-shape) and product-level spanning (U-shape). Organizations face a dual pressure to conform and differentiate (Deephouse 1999). The results suggest that a degree of competitive and institutional pressure for an organization to conform to categorical expectation or deviate from it varies depending on the demand- and competition-side characteristics.

The implication of these studies is consistent with increasing recognition by strategy scholars that "research needs to investigate how contextual factors affect competition, performance, and the development of sustainable competitive advantages” (Marquis and Raynard 2015, 295; see also Ahuja and Yayavaram 2011; Peng et al. 2008) and provides an example of institutional strategies and socio-cultural bridging strategies "by which organizations attend to institutionally diverse settings and capture rents" and create value (Marquis and Raynard 2015, 292). Furthermore, this dissertation adds to the recent academic effort to "reinvigorate the issue of competitive categorization in strategic management research” (Cattani et al. 2015, 6). How a firm is perceived has important implications for strategy formulation, strategy implication, and firm outcomes (Cattani et al. 2015; Hannan et al. 2007; Westphal and Graebner 2010). This dissertation focuses on 
how consumers in local communities perceive firms and suggests that audiences may perceive firms differently depending on their social and economic conditions and develop different preferences towards firms’ category spanning. Firms, accordingly, would find appropriate degrees of category spanning strategies that can appeal to their target audiences, enabling them to achieve sustainable competitive advantages. Future studies would benefit from investigating not only local communities but also various other audiences such as investors (Smith 2011; Smith and Chae 2015), equity analysts (Zuckerman 1999), and media critics (Hsu 2006) to deepen understanding as to how external audiences perceive firms and how they influence value creation and firm performance.

\section{Two levels of spanning and different types of spanners}

In developing arguments about the antecedents of category spanning, I consider organization- and product-level spanning together. By distinguishing between the two levels of firms' spanning activities, this dissertation contributes to a recent academic effort to bridge research on category spanning and organizational identity and strategy research on market diversification and product innovation (Wry et al. 2014). As most of the previous research has examined category spanning at one or the other level (e.g., Hsu 2005; Litov et al 2012; Smith and Chae 2015; Zuckerman 1999), its implications on strategy research have been limited and fragmented. For example, whereas implications of research on category spanning using organizations' market membership is readily applied to assess market diversification, it has been difficult to consider differences in product features that might exist among organizations with the same degree of market diversification. By utilizing detailed product information on 6,072 restaurants and 
applying computational linguistics approaches, I created a novel measure for productlevel spanning that can be applied to assess the innovativeness of a product. The simultaneous analysis of both market membership and product properties enables the identification of different types of spanners (i.e., mixtures, compounds, and multicompounds), providing a more elaborate approach to category spanning and management research and contributing to a growing interest in "the ways in which category spanning leads to variations in outcomes and their evaluation” (Durand and Paolella 2013; Kennedy and Fiss 2013). Also, by examining the relationship among market categories and their structures and elements, the analysis can shed light on research on the emergence and legitimation of new categories from existing ones (Navis and Glynn 2010).

\section{Enduring existence of category spanners}

Examining antecedents of different types of spanners would also contribute to the literature on category spanning by potentially explaining the inconsistent findings on the consequences of category spanning and the enduring existence of category spanners under the dominance of the "categorical imperative” logic (Zuckerman 1999). Despite burgeoning literature on category spanning, findings on its consequences have been inconsistent. While the major stream of research suggests the penalty associated with category spanning (Negro et al. 2010; Leung and Sharkey 2014; Rao et al.; Zuckerman 1999), a group of recent studies has shown a more nuanced effect of category spanning and suggests some boundary conditions to explain the inconsistent effect of category spanning. For example, Smith (2011) suggests advantages of spanning categories by showing that investors allocate capital more readily to nonconforming hedge funds for 
positive performance and withdraw their investment less from nonconforming funds for negative performance compared to conforming counterparts. Pontikes (2012) argues that category spanning has a contrasting consequence on evaluation depending on audiences-i.e. consumers as market-takers and venture capitalist as market-makers. Leung (2014) and Merluzzi and Phillips (2015) also find some positive effects of category spanning of job candidates in the labor market.

While there may be various reasons for the inconsistent findings on the consequences of spanning (e.g., limited coverage of audiences, no attention on the antecedents of spanning, and a lack of consideration of the actual product features that lead firms to claim multiple categories), this dissertation suggests possible conditions under which category spanning may be rewarded instead of being penalized. By examining a full spectrum of the demand side in Study 1, the study overcomes the selection problem of the previous literature, which investigated industries that target only limited groups of consumers (e.g., Hsu 2006; Negro et al. 2010). This study argues that different types of category spanners exist to fill voids in different extremes in the market: mixture organizations, which diversify into multiple market domains but do not engage in product-level spanning, are more likely to be located in underserved distressed markets, whereas compound organizations that provide hybridized, novel offerings appeal to social elites who are early adopters of innovation and contribute to the emergence and legitimation of new products and categories. Indeed, the logic of the categorical imperative may not be universal. Audiences may differ in how they interpret category spanning, and this difference translates into contrasting responses to the same behavior (Pontikes 2012). Even within consumers, some are market-takers and use categories 
passively as a guiding rule to get what they want. Others, more interested in redefining the market structure, are more open to perceiving category spanners as flexible, novel, and appealing. For them categories might be nothing but a useful tool that aids understanding and exploring novel products.

Having said that, future studies should continue to find other important antecedents of firms’ category spanning. In addition, studies that investigate consequences of spanning should first consider antecedents of firms' spanning to accurately evaluate the consequences. As this dissertation is all about finding antecedents of firms’ spanning activities, firms' spanning strategies are not randomly selected. They are elaborately formulated to create and capture value by appealing to target audiences. By taking into account these antecedents, future studies will contribute to better understand the diverging consequences of spanning. 
Figure 1. Levels of Category Spanning

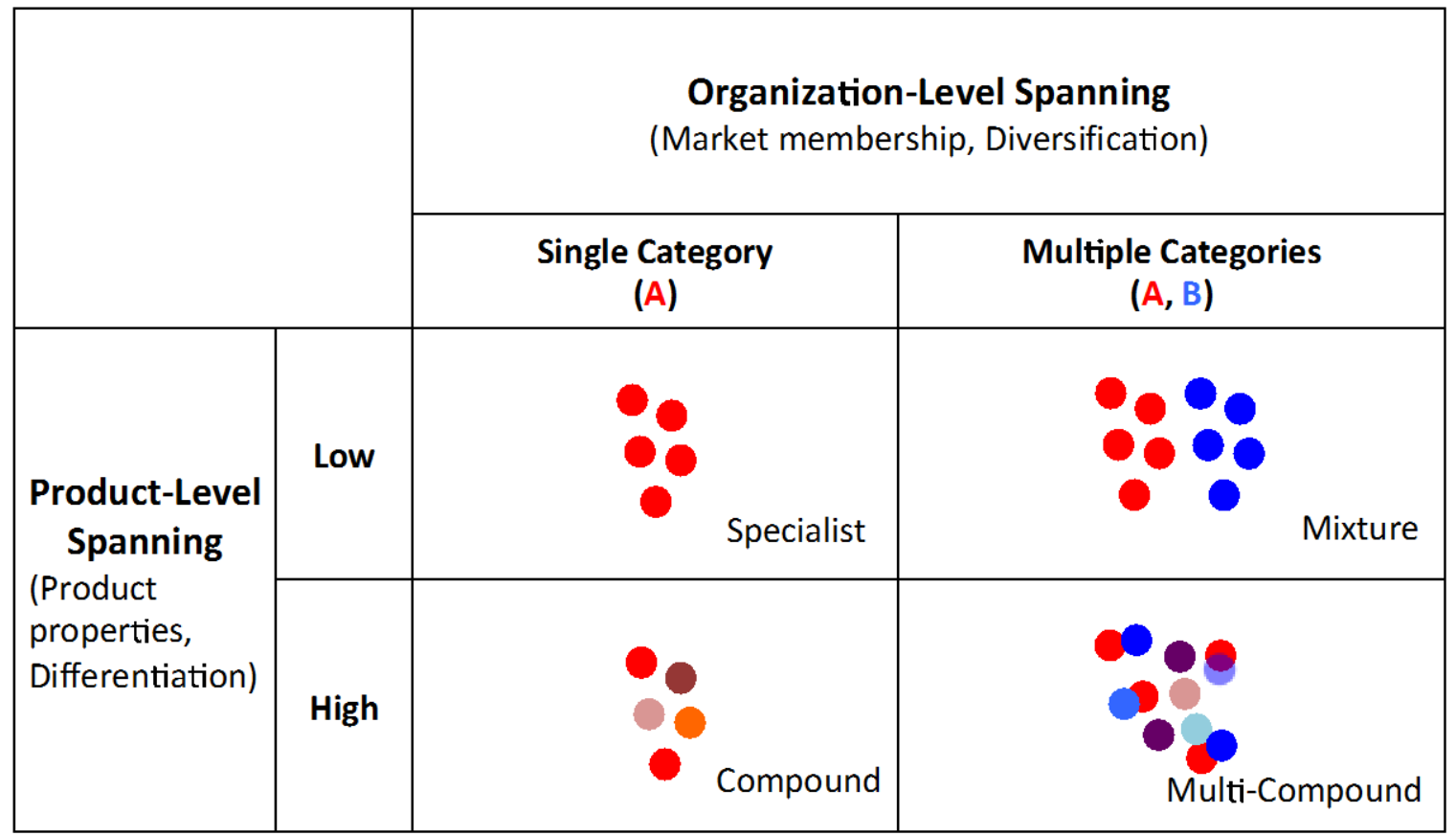


Figure 2. Illustration of the Format of Restaurant Menus on Allmenus.com

\begin{tabular}{|c|c|c|c|}
\hline \multirow{3}{*}{$\begin{array}{l}\text { CHARRED BABY LETTUCE, SPRING ONIONS } \\
\text { Green peas, anchovy emulsion } \\
\text { SHAVED BRUSSELS SPROUTS SALAD } \\
\text { Apple, walnuts, parmesan cheese }\end{array}$} & \multirow{3}{*}{$\begin{array}{r}\$ 11.00 \\
\$ 11.00\end{array}$} & \multicolumn{2}{|c|}{$\begin{array}{l}\text { CHARRED BABY LETTUCE, SPRING ONIONS WITH } \\
\text { VIRGINIA HAM OR CHICKEN BREAST }\end{array}$} \\
\hline & & \multirow{2}{*}{\multicolumn{2}{|c|}{$\begin{array}{l}\text { SHAVED BRUSSELS SPROUTS SALAD WITH DUCK } \\
\text { LEG CONFIT OR PRAWNS } \\
\mathbf{\$ 2 3 . 0 0}\end{array}$}} \\
\hline & & & \\
\hline BABY CARROTS, FENNEL, ORANGE & $\$ 11.00$ & \multirow{2}{*}{\multicolumn{2}{|c|}{$\begin{array}{l}\text { BABY CARROTS, FENNEL, ORANGE WITH SCALLOP } \\
\text { OR WAGYU HANGER } \\
\mathbf{\$ 2 5 . 0 0}\end{array}$}} \\
\hline Pickled shallots, olive oil croutons & & & \\
\hline \multicolumn{4}{|l|}{ Meat, Poultry and Fish } \\
\hline \multicolumn{2}{|c|}{$\begin{array}{l}\text { Choice of aged cheddar or maytag blue cheese served } \\
\text { with steak fries }\end{array}$} & $\begin{array}{l}\text { BRAISED BEEF RIB } \\
\text { House made steak sauce }\end{array}$ & $\$ \mathbf{2 4 . 0 0}$ \\
\hline $\begin{array}{l}\text { WOOD OVEN FIRED WAGYU HANGER STEAK } \\
\text { Charred onion vinaigrette }\end{array}$ & $\$ \mathbf{2 8 . 0 0}$ & $\begin{array}{l}\text { ROASTED PULLED PORK SANDWICH } \\
\text { Garden chow, frisee }\end{array}$ & $\$ 19.00$ \\
\hline $\begin{array}{l}\text { SWORDFISH TARTINE } \\
\text { Provolone, harissa, fennel, greens }\end{array}$ & $\$ 24.00$ & $\begin{array}{l}\text { BUTTERMTLK POACHED CHICKEN BREAST } \\
\text { Preserved lemon, pistachio spring fricassee }\end{array}$ & $\$ 21.00$ \\
\hline $\begin{array}{l}\text { WOOD OVEN ROASTED } \\
\text { Confit of duck leg peas, cured tomato, ramp }\end{array}$ & $\$ 21.00$ & $\begin{array}{l}\text { CRISPY SKIN SALMON } \\
\text { Sorrel cream cucumber, smoked trout roe }\end{array}$ & $\$ \mathbf{2 4 . 0 0}$ \\
\hline SEARED TUNA, CHARRED FENNEL & $\$ \mathbf{2 4 . 0 0}$ & MARKET FISH OF THE DAY & $\$ \mathbf{2 8 . 0 0}$ \\
\hline
\end{tabular}


Figure 3. Examples of Restaurants' Category Spanning

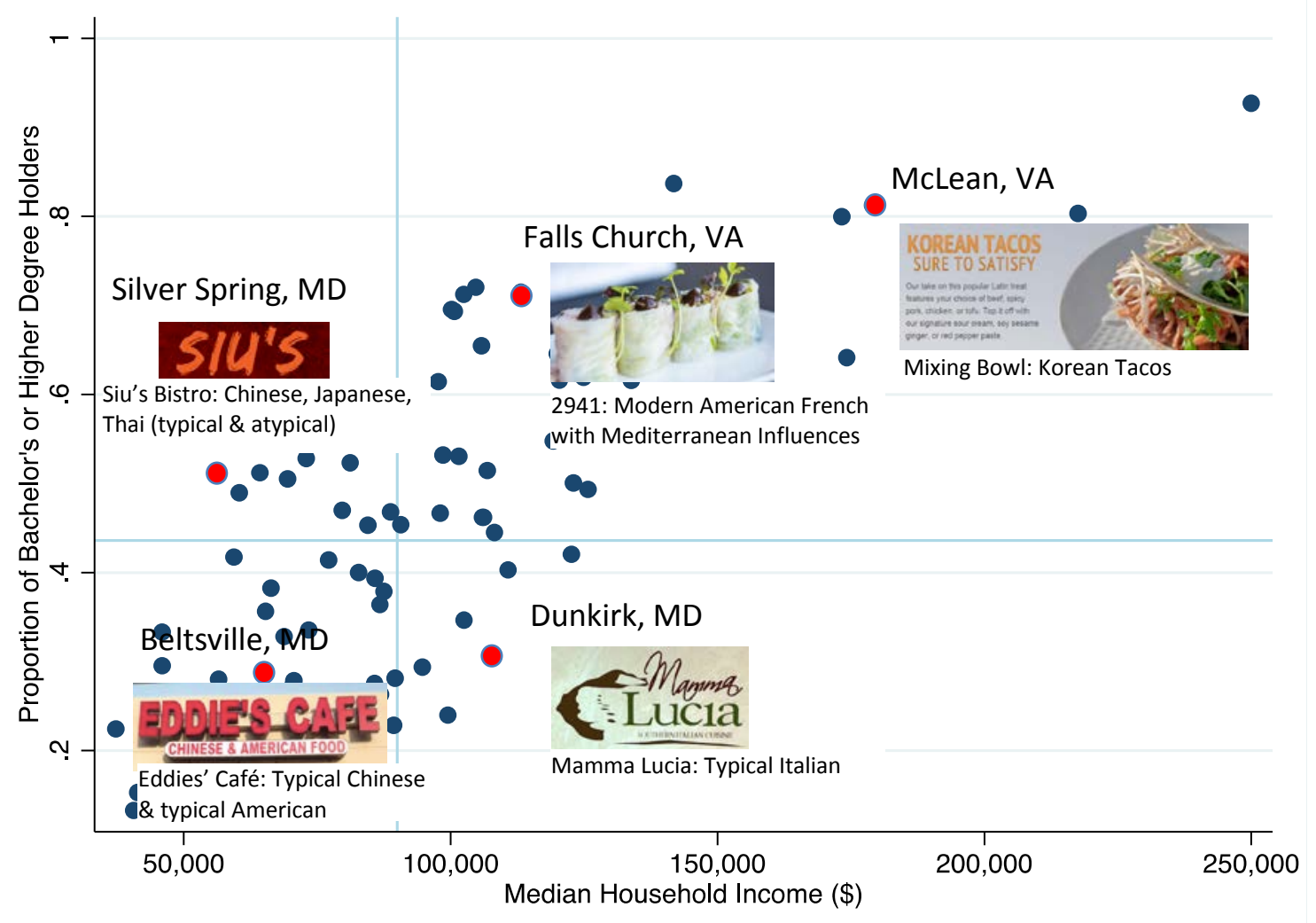


Figure 4. MDS Plot of the Resaurant Industry in the DC-VA-MD-WV Metropolitan Area, by 108 Culinary Styles

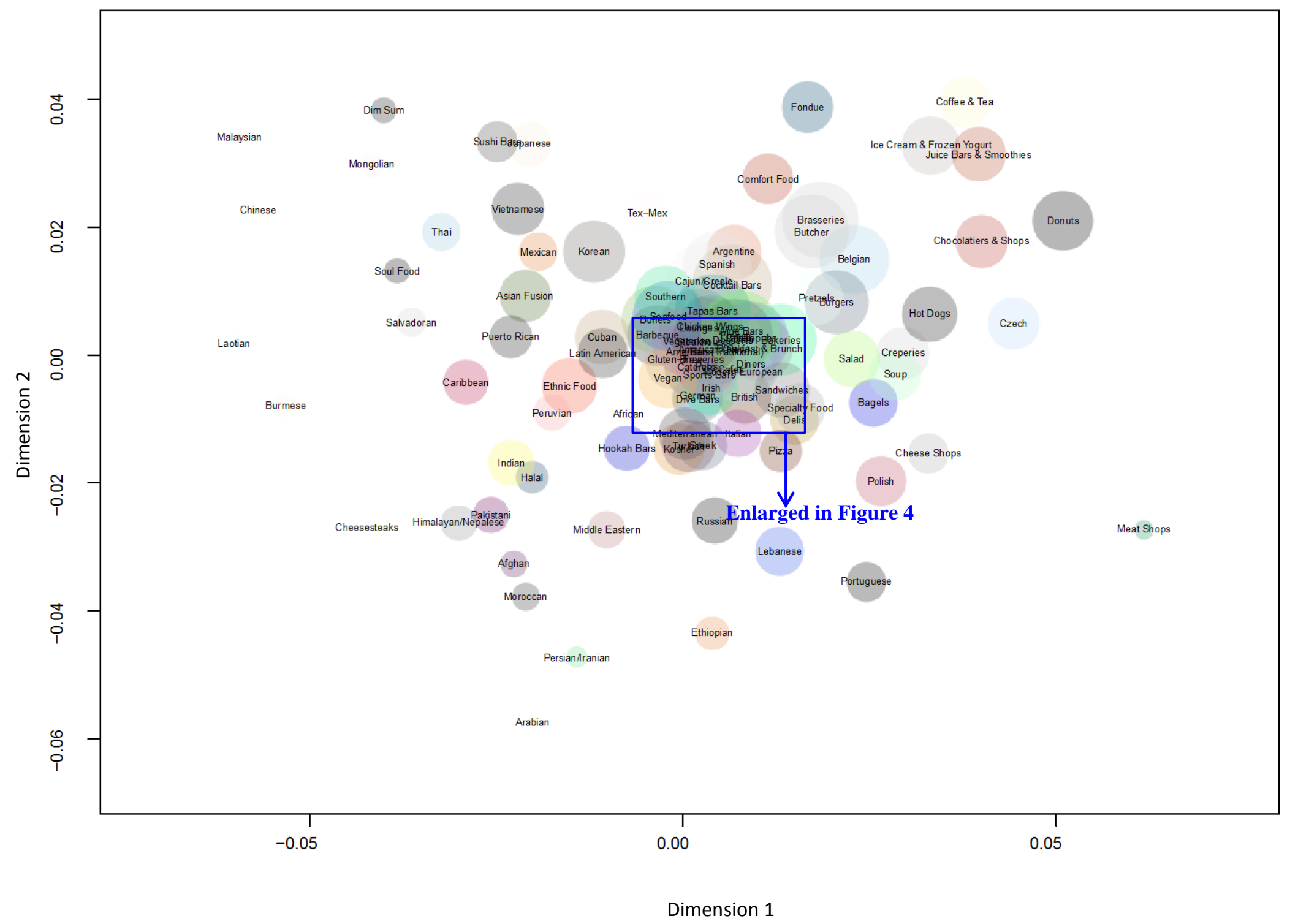


Figure 5. Enlarged MDS Plot of the Restaurant Industry in the DC-VA-MD-WV Metropolitan Area (31 Culinary Styles Positioned in the Center of Figure 4)

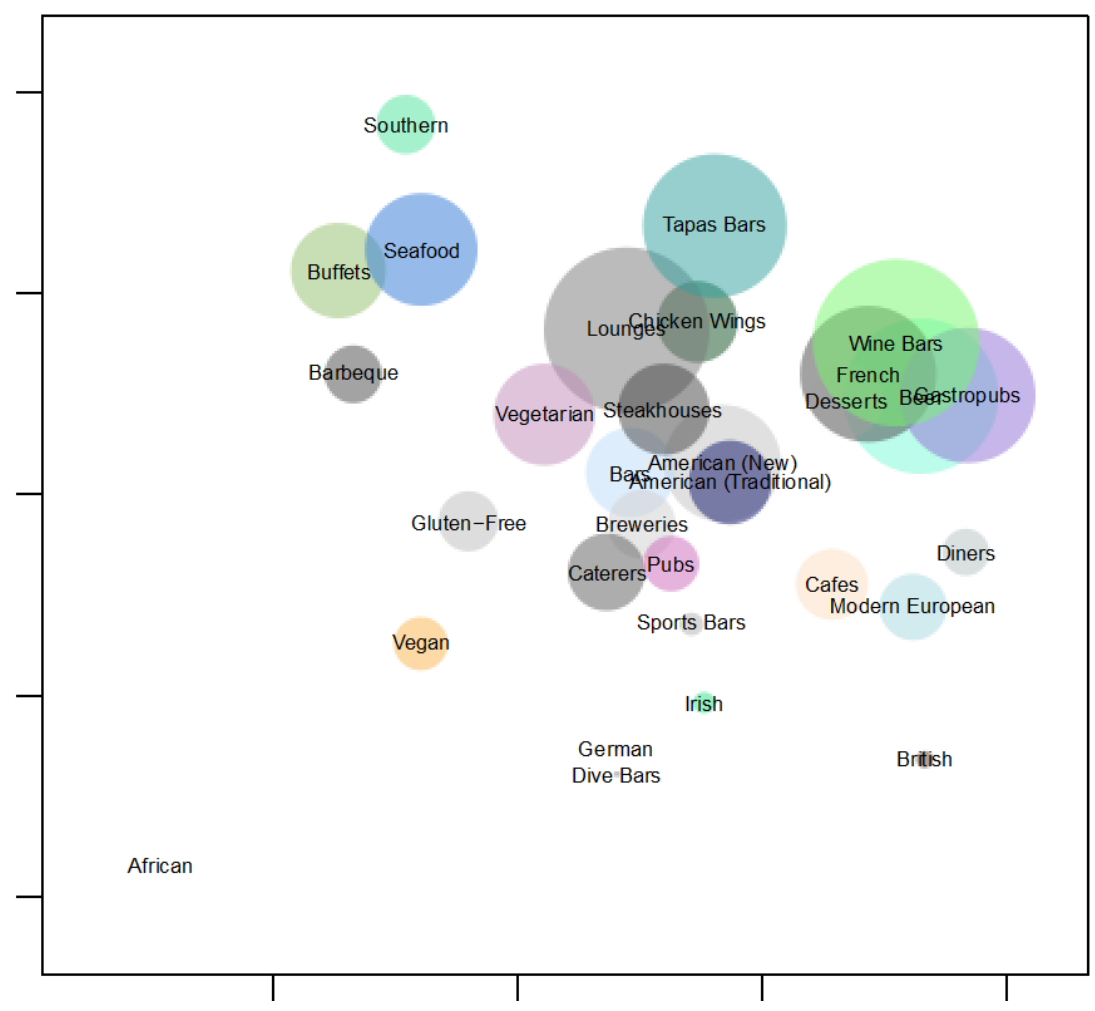


Figure 6. Correspondence Analysis on a Selected Set of Words for Three Culinary Styles

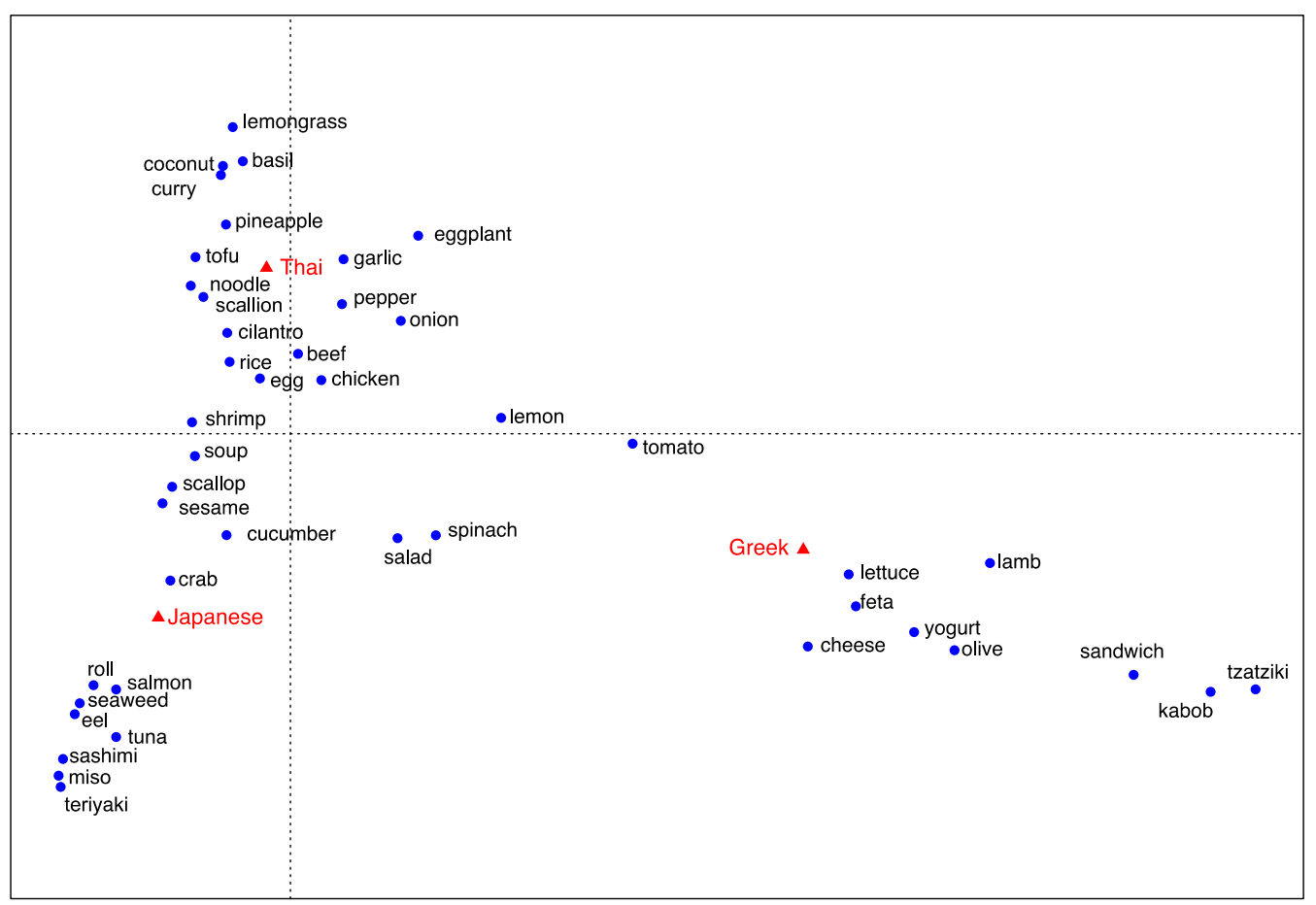


Figure 7. Scatterplot of Organization- and Product-level Spanning of the Sample $(n=6,072)$

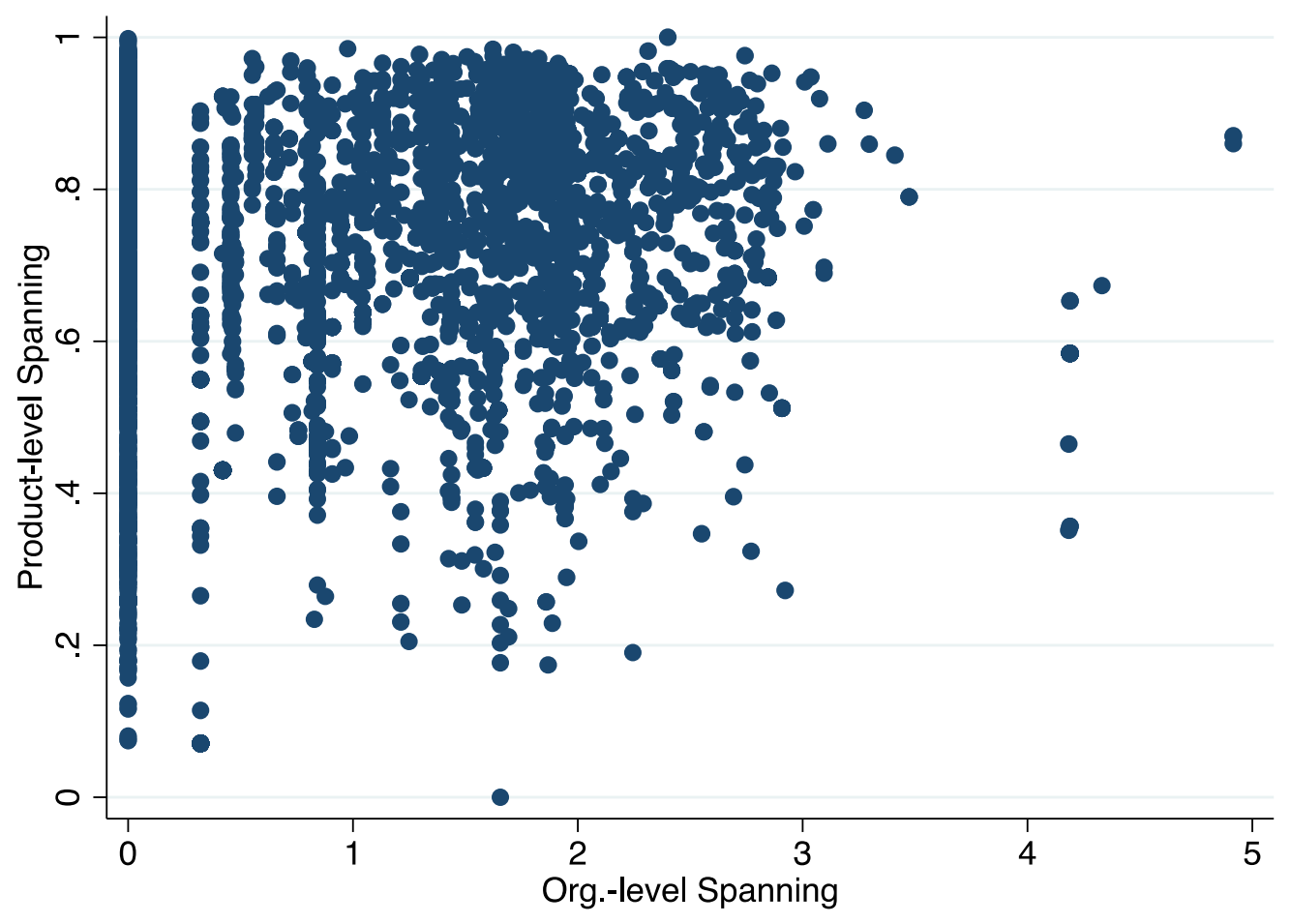




\section{Figure 8. Part of the Menu of Noodles \& Company in Washington, DC}

\section{Noodles \& Pasta}

\section{PENNE ROSA}

Spicy tomato cream sauce, penne pasta, mushrooms, tomato, spinach, wine and parmesan or feta. Try with parmesan-crusted chicken.

\section{WISCONSIN MAC \& CHEESE}

A classic blend of cheddar and jack cheeses, cream and elbow macaroni. Try with oven-roasted meatballs.

\section{PAD THAI}

Rice noodle stir-fry with scrambled egg, carrots, cabbage, sweet chili, citrus, peanuts, Asian sprouts and cilantro. Try with sautéed shrimp.

\section{ALFREDO MONTAMORE}

Spaghetti noodles, four-chees blend, mushrooms, spinach, tomato and parmesan chicken. Topped with

MontAmore cheese, parsley and cracked pepper.

\section{STEAK STROGANOFF}

Marinated steak, mushroom sherry cream sauce, fresh herbs, cracked pepper, sautéed mushrooms, egg noodles and parmesan.

\section{INDONESIAN PEANUT SAUTÉ}

Spicy peanut sauce and rice noodle stir-fry, broccoli, carrots, cabbage, Asian sprouts, cilantro, crushed peanuts and lime. Try with grilled chicken breast.

\section{JAPANESE PAN NOODLES}

Caramelized udon noodles in a sweet soy sauce, broccoli, carrots, shiitake mushrooms, Asian sprouts, black sesame seeds and cilantro. Try with marinated steak.

\section{PESTO CAVATAPPI}

Curly pasta, basil pesto, garlic, mushrooms, tomato, wine, cream, parmesan and Italian parsley. Try with naturally raised pork.

\section{SPAGHETTI \& MEATBALLS}

Five meatballs on spaghetti, crushed tomato marinara and parmesan.

\section{BANGKOK CURRY}

Sweet coconut curry, broccoli, carrots, red bell pepper, onion, mushrooms, a light portion of rice noodles, served on cabbage with black sesame seeds. Try with naturally raised pork.

\section{WHOLE GRAIN TUSCAN FRESCA}

Whole grain linguine with balsamic, olive oil, white wine and roasted garlic, red onion, tomato, spinach and parmesan or feta. Try with grilled chicken breast.

\section{BUTTERED NOODLES}

Tender wavy egg noodles, butter, Italian seasonings and parmesan. Try with oven roasted meatballs. 


\section{Figure 9. Part of the Menu of Teaism in Washington, DC}

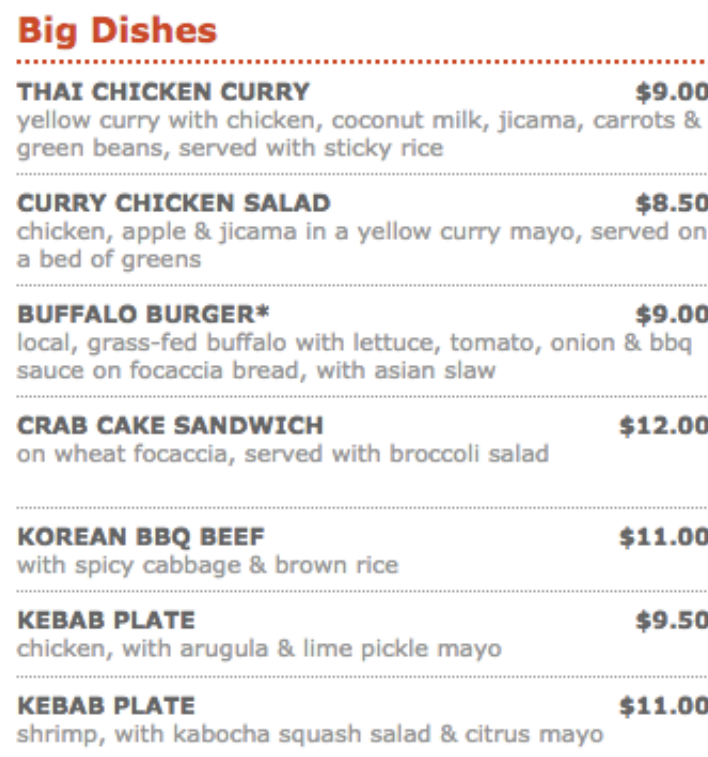

PALAK PANEER

served with raita $\&$ organic basmati brown rice

TOFU NOODLE SALAD

$\$ 8.50$

chilled noodles, tofu, scallions, peppers, mint, peanuts

with soy lime dressing

\section{ORGANIC VEGGIE BURGER}

tofu-shiitake mushroom burger on wheat focaccia with

shiitake mayo and green salad

SEITAN STIR FRY

$\$ 9.75$

with spinach \& arugula in a sweet \& sour sauce, macadamia nuts \& brown rice

\section{KEBAB PLATE}

served with brown rice

Kebab PLATE

$\$ 10.00$

beef, with arugula \& tamarind glaze
9.00

shrimp, with kabocha squash salad \& citrus mayo 
Figure 10. Contrasting Effect of Income and Education on Organization-level Spanning
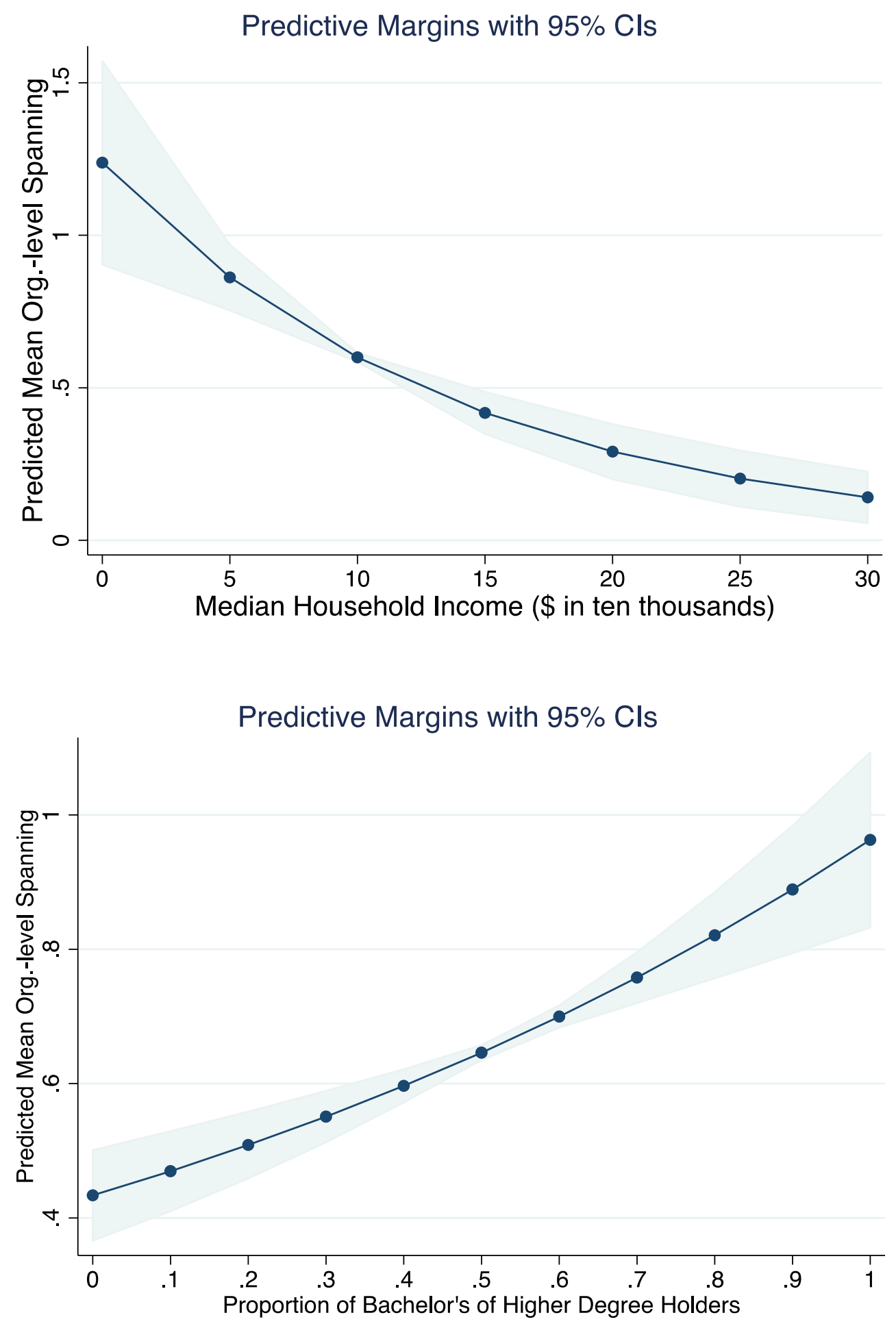
Figure 11. Positive Effect of Education on Product-level Spanning

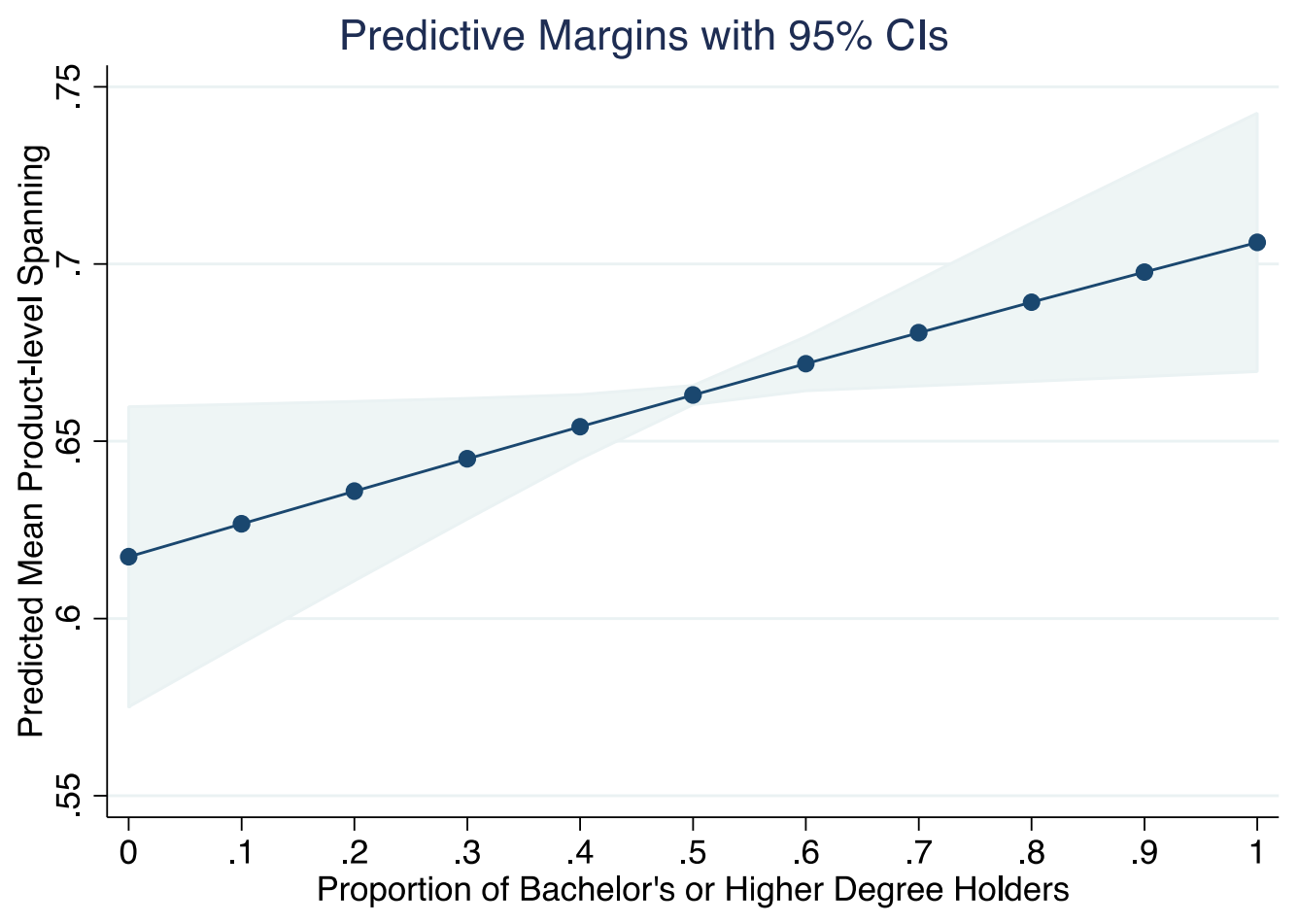


Figure 12. Curvilinear Effect of Category Population on Organization-level Spanning

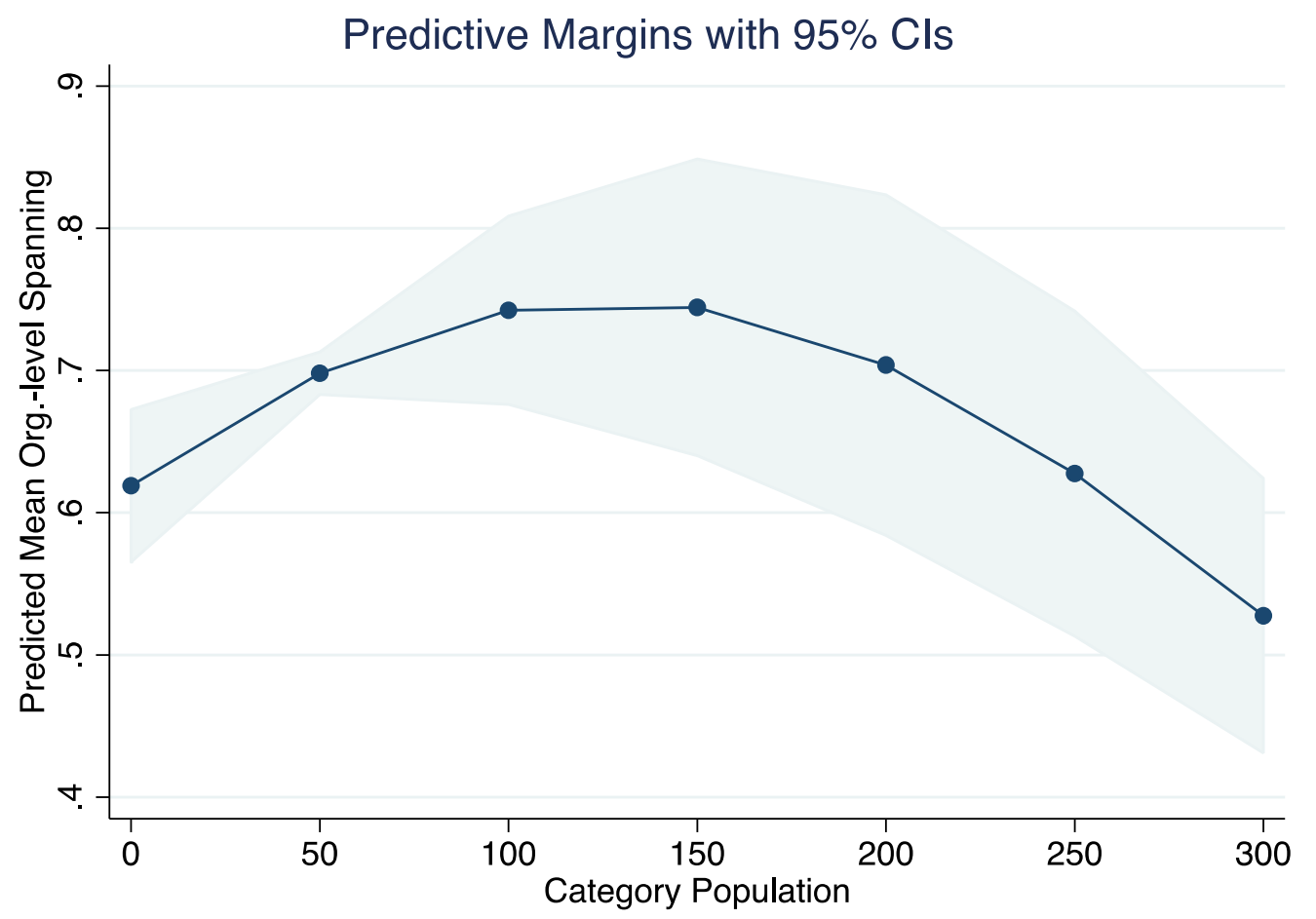


Figure 13. Curvilinear Effect of Category Population on Product-level Spanning

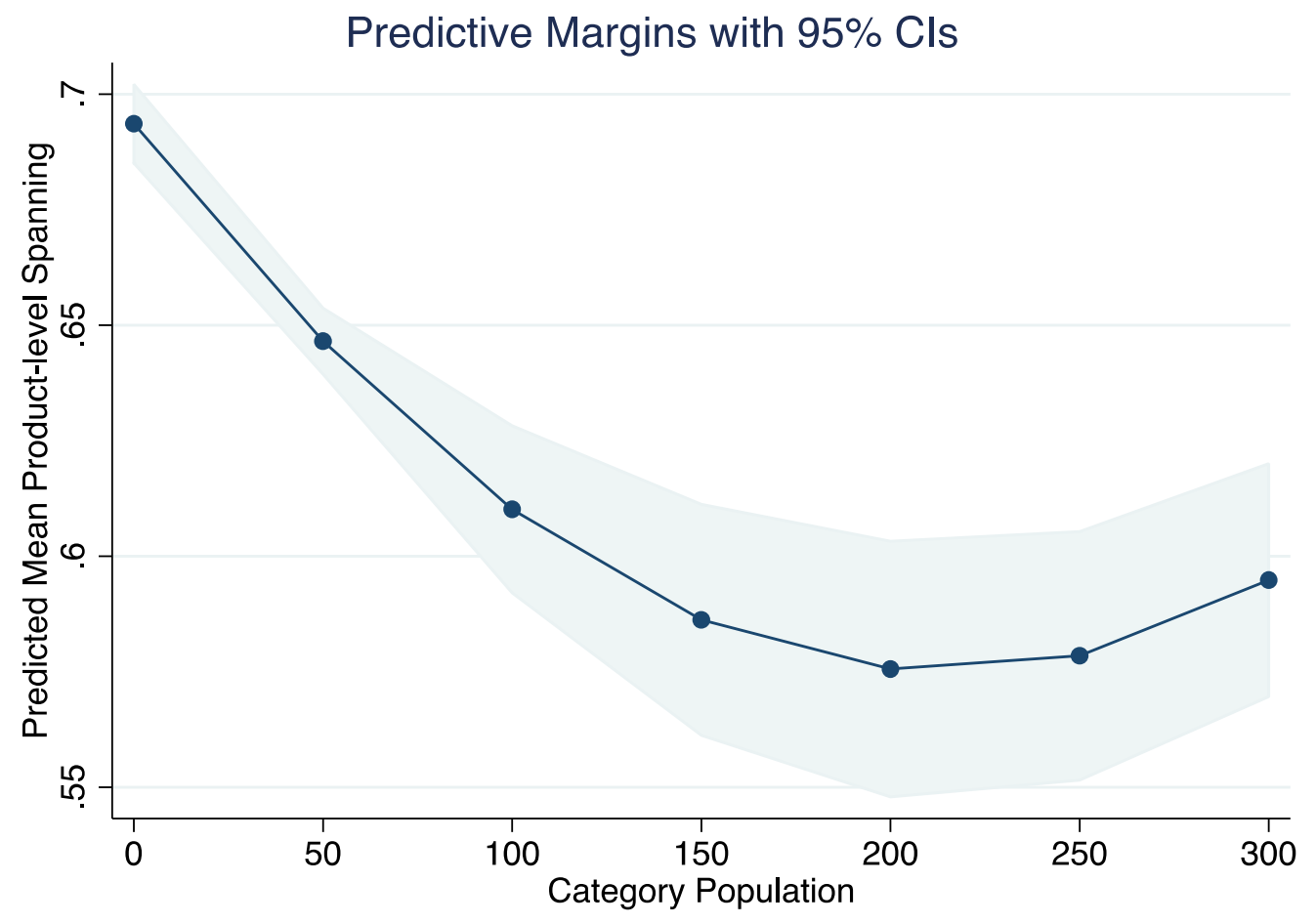


Table 1. 108 Cuisine Categories Listed on Yelp for the Sample Region

\begin{tabular}{|c|c|c|c|}
\hline Afghan & Chinese & Hot dogs & Pretzels \\
\hline African & Chocolatiers & Ice cream \& frozen yogurt & Pubs \\
\hline American (New) & Cocktail bars & Indian & Puerto Rican \\
\hline American (Traditional) & Coffee \& tea & Irish & Russian \\
\hline Arabian & Comfort food & Italian & Salad \\
\hline Argentine & Creperies & Japanese & Salvadoran \\
\hline Asian fusion & Cuban & Juice bars \& smoothies & Sandwiches \\
\hline Bagels & Czech & Korean & Seafood \\
\hline Bakeries & Delis & Kosher & Seafood markets \\
\hline Barbeque & Desserts & Laotian & Slovakian \\
\hline Bars & Dim sum & Latin American & Soul food \\
\hline Beer & Diners & Lebanese & Soup \\
\hline Belgian & Dive bars & Lounges & Southern \\
\hline Brasseries & Dominican & Malaysian & Spanish \\
\hline Brazilian & Donuts & Meat shops & Specialty food \\
\hline Breakfast \& brunch & Ethiopian & Mediterranean & Sports bars \\
\hline British & Ethnic food & Mexican & Steakhouses \\
\hline Breweries & Fish \& chips & Middle Eastern & Sushi bars \\
\hline Buffets & Fondue & Modern European & Tapas bars \\
\hline Burgers & French & Mongolian & Tex-Mex \\
\hline Burmese & Gastropubs & Moroccan & Thai \\
\hline Cafes & German & Pakistani & Turkish \\
\hline Cajun \& Creole & Gluten-free & Persian \& Iranian & Vegan \\
\hline Caribbean & Greek & Peruvian & Vegetarian \\
\hline Cheese shops & Halal & Pizza & Vietnamese \\
\hline Cheesesteaks & Himalayan \& Nepalese & Polish & Wine \& spirits \\
\hline Chicken wings & Hookah bars & Portuguese & Wine bars \\
\hline
\end{tabular}


Table 2. Descriptive Statistics and Correlations $(\mathrm{N}=6,072)$

\begin{tabular}{|c|c|c|c|c|c|c|c|c|c|c|c|c|c|c|}
\hline & Mean & S.D. & Min & Max & 1 & 2 & 3 & 4 & 5 & 6 & 7 & 8 & 9 & 10 \\
\hline 1. Organization-level Spanning & 0.66 & 0.89 & 0 & 4.92 & 1 & & & & & & & & & \\
\hline 2. Product-level Spanning & 0.66 & 0.2 & 0 & 1 & 0.24 & 1 & & & & & & & & \\
\hline 3. Income (in $\$ 10,000 \mathrm{~s}$ ) & 8.75 & 2.87 & 3.73 & 25 & -0.02 & -0.04 & 1 & & & & & & & \\
\hline 4. Education & 0.52 & 0.15 & 0.13 & 0.93 & 0.06 & 0.12 & 0.68 & 1 & & & & & & \\
\hline 5. \% Bachelor & 0.26 & 0.06 & 0.09 & 0.46 & 0.04 & 0.01 & 0.62 & 0.8 & 1 & & & & & \\
\hline 6. \% Master & 0.17 & 0.06 & 0.02 & 0.31 & 0.05 & 0.11 & 0.64 & 0.95 & 0.76 & 1 & & & & \\
\hline 7. \% Dr. & 0.04 & 0.02 & 0 & 0.12 & 0.05 & 0.13 & 0.4 & 0.69 & 0.27 & 0.61 & 1 & & & \\
\hline 8. \# of orgs. in category (in 100s) & 0.41 & 0.59 & 0.01 & 2.64 & 0.16 & 0.07 & -0.35 & 0.03 & -0.15 & 0.03 & 0.07 & 1 & & \\
\hline 9. Income diversity & 0.9 & 0.04 & 0.63 & 0.93 & 0.03 & 0.03 & -0.92 & -0.54 & -0.41 & -0.49 & -0.42 & 0.31 & 1 & \\
\hline 10. Education diversity & 0.8 & 0.03 & 0.69 & 0.83 & 0.09 & 0.19 & -0.38 & 0.19 & -0.05 & 0.17 & 0.39 & 0.52 & 0.4 & 1 \\
\hline 11. Ethnic diversity & 0.59 & 0.11 & 0.1 & 0.76 & 0.02 & -0.02 & -0.45 & -0.28 & -0.1 & -0.27 & -0.23 & 0.13 & 0.51 & 0.46 \\
\hline 12. Population density (in 1,000 s/miles ${ }^{2}$ ) & 5.92 & 2.49 & 0.1 & 8.5 & 0.07 & 0.19 & -0.39 & 0.23 & 0.04 & 0.26 & 0.18 & 0.49 & 0.41 & 0.64 \\
\hline 13. Total \# of orgs. (in 100s) & 5.46 & 6.33 & 0.06 & 16.08 & 0.1 & 0.24 & -0.46 & 0.06 & -0.2 & 0.06 & 0.12 & 0.73 & 0.41 & 0.72 \\
\hline 14. \% of pop., age in $20 \mathrm{~s}$ & 0.17 & 0.05 & 0.04 & 0.37 & 0.07 & 0.13 & -0.64 & -0.12 & -0.17 & -0.07 & -0.14 & 0.4 & 0.61 & 0.43 \\
\hline 15. DC & 0.25 & 0.43 & 0 & 1 & 0.09 & 0.22 & -0.47 & -0.05 & -0.31 & -0.05 & 0.09 & 0.71 & 0.39 & 0.69 \\
\hline 16. Central County & 0.93 & 0.25 & 0 & 1 & 0.03 & 0.08 & 0.2 & 0.39 & 0.31 & 0.39 & 0.23 & 0.13 & -0.11 & 0.33 \\
\hline 17. Median rent (in $\$ 1,000$ s) & 1.44 & 0.27 & 0.63 & 2 & -0.01 & -0.07 & 0.81 & 0.55 & 0.67 & 0.54 & 0.33 & -0.36 & -0.68 & -0.29 \\
\hline 18. Org. age (in years) & 4.53 & 2.35 & 0 & 9.54 & 0.06 & 0.08 & 0.09 & 0.21 & 0.18 & 0.2 & 0.13 & 0.04 & -0.06 & 0.13 \\
\hline 19. Chain & 0.61 & 0.49 & 0 & 1 & -0.07 & -0.35 & 0.03 & -0.18 & -0.07 & -0.17 & -0.15 & -0.06 & -0.04 & -0.26 \\
\hline 20. Fast food & 0.16 & 0.37 & 0 & 1 & -0.2 & -0.13 & -0.03 & -0.17 & -0.1 & -0.16 & -0.14 & -0.11 & 0.01 & -0.17 \\
\hline 21. Price="\$\$" & 0.51 & 0.5 & 0 & 1 & 0.12 & -0.07 & 0.08 & 0.09 & 0.09 & 0.08 & 0.04 & -0.07 & -0.05 & 0 \\
\hline 22. Price=" $\$ \$ \$ "$ & 0.05 & 0.22 & 0 & 1 & 0.04 & 0.19 & 0 & 0.05 & 0 & 0.03 & 0.07 & 0.01 & -0.01 & 0.07 \\
\hline 23. Price=" \$\$ & 0.01 & 0.09 & 0 & 1 & 0.03 & 0.09 & 0.01 & 0.03 & 0 & 0.02 & 0.03 & 0 & -0.02 & 0.02 \\
\hline 24. Sunday closed & 0.06 & 0.24 & 0 & 1 & 0.06 & 0.12 & -0.06 & 0.05 & -0.02 & 0.04 & 0.06 & 0.17 & 0.04 & 0.15 \\
\hline 25. Closed before 7pm & 0.05 & 0.21 & 0 & 1 & 0.08 & 0.11 & -0.06 & 0.04 & -0.02 & 0.04 & 0.06 & 0.25 & 0.04 & 0.14 \\
\hline
\end{tabular}




\begin{tabular}{|c|c|c|c|c|c|c|c|c|c|c|c|c|c|c|c|}
\hline & 11 & 12 & 13 & 14 & 15 & 16 & 17 & 18 & 19 & 20 & 21 & 22 & 23 & 24 & 25 \\
\hline \multicolumn{16}{|l|}{ 1. Org. Span } \\
\hline \multicolumn{16}{|l|}{ 2. Product Span } \\
\hline \multicolumn{16}{|l|}{ 3. Income (in $\$ 10,000 \mathrm{~s}$ ) } \\
\hline \multicolumn{16}{|l|}{ 4. Education } \\
\hline \multicolumn{16}{|l|}{ 5. \% Bachelor } \\
\hline \multicolumn{16}{|l|}{ 6. \% Master } \\
\hline \multicolumn{16}{|l|}{ 7. \% Dr. } \\
\hline \multicolumn{16}{|l|}{ 8. \# of orgs. in category } \\
\hline \multicolumn{16}{|l|}{ 9. Income diversity } \\
\hline \multicolumn{16}{|l|}{ 10. Education diversity } \\
\hline 11. Ethnic diversity & 1 & & & & & & & & & & & & & & \\
\hline 12. Population density (in 1,000s/miles2) & 0.22 & 1 & & & & & & & & & & & & & \\
\hline 13. Total \# of orgs. (in 100s) & 0.16 & 0.67 & 1 & & & & & & & & & & & & \\
\hline 14. \% of pop., age in $20 \mathrm{~s}$ & 0.29 & 0.57 & 0.54 & 1 & & & & & & & & & & & \\
\hline 15. DC & 0.15 & 0.58 & 0.98 & 0.46 & 1 & & & & & & & & & & \\
\hline 16. Central County & 0.14 & 0.32 & 0.19 & 0.09 & 0.16 & 1 & & & & & & & & & \\
\hline 17. Median rent (in $\$ 1,000$ s) & -0.18 & -0.32 & -0.48 & -0.49 & -0.52 & 0.28 & 1 & & & & & & & & \\
\hline 18. Org. age (in years) & 0.01 & 0.13 & 0.1 & 0.03 & 0.07 & 0.12 & 0.07 & 1 & & & & & & & \\
\hline 19. Chain & -0.03 & -0.26 & -0.27 & -0.15 & -0.24 & -0.13 & 0.05 & -0.16 & 1 & & & & & & \\
\hline 20. Fast food & -0.02 & -0.16 & -0.16 & -0.07 & -0.13 & -0.09 & -0.02 & -0.15 & 0.28 & 1 & & & & & \\
\hline 21. Price="\$\$" & -0.01 & 0 & -0.02 & -0.03 & -0.03 & 0.01 & 0.07 & 0.13 & -0.1 & -0.44 & 1 & & & & \\
\hline 22. Price $=" \$ \$ \$ "$ & -0.03 & 0.05 & 0.11 & 0.03 & 0.11 & 0.01 & -0.04 & 0.05 & -0.19 & -0.1 & -0.23 & 1 & & & \\
\hline 23. Price=" $\$ \$ \$ "$ & -0.02 & 0.02 & 0.04 & 0.01 & 0.04 & 0 & -0.01 & 0.07 & -0.02 & -0.04 & -0.09 & -0.02 & 1 & & \\
\hline 24. Sunday closed & 0.01 & 0.12 & 0.19 & 0.11 & 0.18 & 0.04 & -0.07 & 0.01 & -0.1 & -0.05 & -0.09 & 0.05 & 0.06 & 1 & \\
\hline 25. Closed before 7pm & 0 & 0.13 & 0.2 & 0.09 & 0.19 & 0.05 & -0.07 & 0.01 & -0.06 & -0.05 & -0.1 & -0.03 & -0.01 & 0.41 & 1 \\
\hline
\end{tabular}


Table 3. GLM Regression Predicting Organization-level Spanning (H1, H2)

\begin{tabular}{|c|c|c|c|c|c|c|}
\hline & Model 1 & Model 2 & Model 3 & Model 4 & Model 5 & Model 6 \\
\hline Income & & $\begin{array}{c}-0.0191 \\
(0.015)\end{array}$ & & $\begin{array}{c}-0.0691 * * * \\
(0.015)\end{array}$ & & $\begin{array}{c}-0.0367+ \\
(0.023)\end{array}$ \\
\hline Education & & & $\begin{array}{c}0.3224 * * \\
(0.130)\end{array}$ & $\begin{array}{c}0.7979 * * * \\
(0.148)\end{array}$ & & \\
\hline Bachelor's & & & & & $\begin{array}{l}-0.2841 \\
(0.360)\end{array}$ & $\begin{array}{l}-0.1619 \\
(0.323)\end{array}$ \\
\hline Master's & & & & & $\begin{array}{c}0.5127 * \\
(0.286)\end{array}$ & $\begin{array}{l}1.0143 * \\
(0.431)\end{array}$ \\
\hline PhD & & & & & $\begin{array}{c}2.4009 * * * \\
(0.687)\end{array}$ & $\begin{array}{c}2.0267 * * \\
(0.674)\end{array}$ \\
\hline Income diversity & $\begin{array}{c}-0.1459 \\
(0.340)\end{array}$ & $\begin{array}{c}-1.0744 \\
(0.824)\end{array}$ & $\begin{array}{l}0.4953 \\
(0.353)\end{array}$ & $\begin{array}{c}-1.8982 * * \\
(0.716)\end{array}$ & $\begin{array}{c}0.8146 * \\
(0.326)\end{array}$ & $\begin{array}{l}-0.7095 \\
(0.929)\end{array}$ \\
\hline Education diversity & $\begin{array}{l}-0.4871 \\
(0.728)\end{array}$ & $\begin{array}{l}-0.4629 \\
(0.685)\end{array}$ & $\begin{array}{l}-1.1731 \\
(0.783)\end{array}$ & $\begin{array}{c}-2.0749 * * * \\
(0.545)\end{array}$ & $\begin{array}{c}-2.9597 * * \\
(0.909)\end{array}$ & $\begin{array}{c}-2.9082^{* * * *} \\
(0.807)\end{array}$ \\
\hline Ethnic diversity & $\begin{array}{c}-0.0316 \\
(0.139)\end{array}$ & $\begin{array}{l}-0.0710 \\
(0.143)\end{array}$ & $\begin{array}{l}0.0781 \\
(0.139)\end{array}$ & $\begin{array}{l}0.0894 \\
(0.112)\end{array}$ & $\begin{array}{c}0.2765^{*} \\
(0.139)\end{array}$ & $\begin{array}{c}0.2323+ \\
(0.135)\end{array}$ \\
\hline Population density & $\begin{array}{l}0.0039 \\
(0.007)\end{array}$ & $\begin{array}{l}0.0026 \\
(0.007)\end{array}$ & $\begin{array}{l}0.0015 \\
(0.007)\end{array}$ & $\begin{array}{l}-0.0066 \\
(0.007)\end{array}$ & $\begin{array}{l}-0.0015 \\
(0.006)\end{array}$ & $\begin{array}{l}-0.0059 \\
(0.006)\end{array}$ \\
\hline Total number of orgs. & $\begin{array}{l}-0.0127 \\
(0.011)\end{array}$ & $\begin{array}{l}-0.0063 \\
(0.013)\end{array}$ & $\begin{array}{c}-0.0273^{*} \\
(0.012)\end{array}$ & $\begin{array}{c}-0.0253^{*} \\
(0.013)\end{array}$ & $\begin{array}{l}-0.0139 \\
(0.011)\end{array}$ & $\begin{array}{l}-0.0111 \\
(0.012)\end{array}$ \\
\hline$\%$ of pop., age in $20 \mathrm{~s}$ & $\begin{array}{c}0.3422 \\
(0.235)\end{array}$ & $\begin{array}{l}0.1349 \\
(0.283)\end{array}$ & $\begin{array}{c}0.4098+ \\
(0.215)\end{array}$ & $\begin{array}{l}-0.2523 \\
(0.273)\end{array}$ & $\begin{array}{c}0.3521+ \\
(0.201)\end{array}$ & $\begin{array}{l}-0.0357 \\
(0.283)\end{array}$ \\
\hline Median rent & $\begin{array}{l}0.0457 \\
(0.055)\end{array}$ & $\begin{array}{l}0.0870 \\
(0.076)\end{array}$ & $\begin{array}{l}0.0156 \\
(0.048)\end{array}$ & $\begin{array}{c}0.1165+ \\
(0.068)\end{array}$ & $\begin{array}{l}0.0064 \\
(0.059)\end{array}$ & $\begin{array}{l}0.0563 \\
(0.095)\end{array}$ \\
\hline DC & $\begin{array}{l}0.1853 \\
(0.149)\end{array}$ & $\begin{array}{l}0.0894 \\
(0.182)\end{array}$ & $\begin{array}{c}0.4035^{*} \\
(0.169)\end{array}$ & $\begin{array}{c}0.3722 * \\
(0.171)\end{array}$ & $\begin{array}{l}0.2518 \\
(0.155)\end{array}$ & $\begin{array}{l}0.2043 \\
(0.154)\end{array}$ \\
\hline Central county & $\begin{array}{l}-0.0067 \\
(0.038)\end{array}$ & $\begin{array}{l}0.0134 \\
(0.042)\end{array}$ & $\begin{array}{l}-0.0237 \\
(0.038)\end{array}$ & $\begin{array}{l}0.0266 \\
(0.043)\end{array}$ & $\begin{array}{l}0.0229 \\
(0.041)\end{array}$ & $\begin{array}{l}0.0447 \\
(0.043)\end{array}$ \\
\hline Org. age & $\begin{array}{l}-0.0023 \\
(0.005)\end{array}$ & $\begin{array}{l}-0.0021 \\
(0.005)\end{array}$ & $\begin{array}{l}-0.0027 \\
(0.005)\end{array}$ & $\begin{array}{l}-0.0026 \\
(0.005)\end{array}$ & $\begin{array}{l}-0.0022 \\
(0.005)\end{array}$ & $\begin{array}{l}-0.0021 \\
(0.005)\end{array}$ \\
\hline Chain & $\begin{array}{c}-0.2603^{* * *} \\
(0.041)\end{array}$ & $\begin{array}{c}-0.2627 * * * \\
(0.040)\end{array}$ & $\begin{array}{c}-0.2578 * * * \\
(0.041)\end{array}$ & $\begin{array}{c}-0.2630 * * * \\
(0.040)\end{array}$ & $\begin{array}{c}-0.2622^{* * *} \\
(0.040)\end{array}$ & $\begin{array}{c}-0.2649 * * * \\
(0.040)\end{array}$ \\
\hline Fast food & $\begin{array}{c}-1.1071 * * * \\
(0.072)\end{array}$ & $\begin{array}{c}-1.1074 * * * \\
(0.072)\end{array}$ & $\begin{array}{c}-1.1029 * * * \\
(0.072)\end{array}$ & $\begin{array}{c}-1.0976 * * * \\
(0.072)\end{array}$ & $\begin{array}{c}-1.0981^{* * *} \\
(0.072)\end{array}$ & $\begin{array}{c}-1.0990^{* * *} \\
(0.072)\end{array}$ \\
\hline Price=" $\$ \$ "$ & $\begin{array}{c}0.1829 * * \\
(0.067)\end{array}$ & $\begin{array}{c}0.1844 * * \\
(0.068)\end{array}$ & $\begin{array}{c}0.1811^{* *} \\
(0.066)\end{array}$ & $\begin{array}{c}0.1842 * * \\
(0.067)\end{array}$ & $\begin{array}{c}0.1829 * * \\
(0.067)\end{array}$ & $\begin{array}{c}0.1842 * * \\
(0.068)\end{array}$ \\
\hline Price $=“ \$ \$ \$ ”$ & $\begin{array}{l}0.1456 \\
(0.125)\end{array}$ & $\begin{array}{l}0.1494 \\
(0.124)\end{array}$ & $\begin{array}{l}0.1410 \\
(0.124)\end{array}$ & $\begin{array}{l}0.1480 \\
(0.123)\end{array}$ & $\begin{array}{l}0.1464 \\
(0.123)\end{array}$ & $\begin{array}{l}0.1510 \\
(0.123)\end{array}$ \\
\hline Price=“\$\$\$\$” & $\begin{array}{c}0.3350 * * * \\
(0.074)\end{array}$ & $\begin{array}{c}0.3333 * * * \\
(0.076)\end{array}$ & $\begin{array}{c}0.3411 * * * \\
(0.072)\end{array}$ & $\begin{array}{c}0.3437 * * * \\
(0.074)\end{array}$ & $\begin{array}{c}0.3379 * * * \\
(0.077)\end{array}$ & $\begin{array}{c}0.3399 * * * \\
(0.078)\end{array}$ \\
\hline Sunday closed & $\begin{array}{l}0.0174 \\
(0.032)\end{array}$ & $\begin{array}{l}0.0181 \\
(0.032)\end{array}$ & $\begin{array}{l}0.0148 \\
(0.031)\end{array}$ & $\begin{array}{l}0.0135 \\
(0.032)\end{array}$ & $\begin{array}{l}0.0141 \\
(0.032)\end{array}$ & $\begin{array}{l}0.0142 \\
(0.032)\end{array}$ \\
\hline Closed before $7 \mathrm{pm}$ & $\begin{array}{l}0.0229 \\
(0.031)\end{array}$ & $\begin{array}{c}0.0219 \\
(0.031)\end{array}$ & $\begin{array}{c}0.0258 \\
(0.030)\end{array}$ & $\begin{array}{c}0.0262 \\
(0.030)\end{array}$ & $\begin{array}{c}0.0234 \\
(0.030)\end{array}$ & $\begin{array}{c}0.0237 \\
(0.031)\end{array}$ \\
\hline Constant & $\begin{array}{c}-2.3240 * * * \\
(0.686)\end{array}$ & $\begin{array}{l}-1.3655 \\
(0.963)\end{array}$ & $\begin{array}{c}-2.5003 * * * \\
(0.640)\end{array}$ & $\begin{array}{l}0.6825 \\
(0.839)\end{array}$ & $\begin{array}{c}-1.4541^{*} \\
(0.702)\end{array}$ & $\begin{array}{l}0.1162 \\
(1.069)\end{array}$ \\
\hline Fixed Effects, Category (107) & Yes & Yes & Yes & Yes & Yes & Yes \\
\hline Number of Cities & 85 & 85 & 85 & 85 & 85 & 85 \\
\hline$N$ & 6,072 & 6,072 & 6,072 & 6,072 & 6,072 & 6,072 \\
\hline Log-pseudo-likelihood & -4126.18 & -4125.90 & -4125.44 & -4123.28 & -4123.65 & -4123.09 \\
\hline
\end{tabular}

Robust standard errors clustered by city in parentheses; ${ }^{+} p<0.10$; ${ }^{*} p<0.05 ; * * p<0.01$; ${ }^{* * *} p<0.001$.

$T$-tests were one-tailed for hypothesized effects and two-tailed for control variables. 
Table 4. GLM Regression Predicting Organization-level Spanning (Robustness Check)

\begin{tabular}{|c|c|c|c|c|c|}
\hline & Model 7 & Model 8 & Model 9 & Model 10 & Model 11 \\
\hline Income & $\begin{array}{c}-0.0639 * * * \\
(0.012)\end{array}$ & $\begin{array}{c}-0.0372^{*} \\
(0.020)\end{array}$ & & $\begin{array}{c}-0.0630 * * * \\
(0.013)\end{array}$ & $\begin{array}{c}-0.0351^{*} \\
(0.021)\end{array}$ \\
\hline Education & $\begin{array}{c}0.8219 * * * \\
(0.151)\end{array}$ & & & $\begin{array}{c}0.8294 * * * \\
(0.149)\end{array}$ & \\
\hline Bachelor's & & $\begin{array}{r}-0.0827 \\
(0.311)\end{array}$ & & & $\begin{array}{l}-0.0223 \\
(0.305)\end{array}$ \\
\hline Master's & & $\begin{array}{c}1.1805 * * \\
(0.388)\end{array}$ & & & $\begin{array}{c}1.1005 * * \\
(0.375)\end{array}$ \\
\hline PhD & & $\begin{array}{c}1.7853^{* *} \\
(0.683)\end{array}$ & & & $\begin{array}{c}1.8473^{* *} \\
(0.686)\end{array}$ \\
\hline \# of orgs. in category & & & $\begin{array}{c}0.6079 * \\
(0.283)\end{array}$ & $\begin{array}{c}0.6072 * \\
(0.276)\end{array}$ & $\begin{array}{c}0.5622 * \\
(0.261)\end{array}$ \\
\hline (\# of orgs. in category) $^{2}$ & & & $\begin{array}{c}-0.7246 * * \\
(0.274)\end{array}$ & $\begin{array}{c}-0.7452^{* *} \\
(0.270)\end{array}$ & $\begin{array}{c}-0.6619 * * \\
(0.254)\end{array}$ \\
\hline Income diversity & $\begin{array}{c}-1.6278 * * \\
(0.593)\end{array}$ & $\begin{array}{l}-0.7030 \\
(0.820)\end{array}$ & $\begin{array}{c}-0.2268 \\
(0.359)\end{array}$ & $\begin{array}{c}-1.6351 * * \\
(0.582)\end{array}$ & $\begin{array}{l}-0.6904 \\
(0.839)\end{array}$ \\
\hline Education diversity & $\begin{array}{c}-2.1182 * * * \\
(0.476)\end{array}$ & $\begin{array}{c}-2.7917 * * * \\
(0.778)\end{array}$ & $\begin{array}{r}-0.7760 \\
(0.668)\end{array}$ & $\begin{array}{c}-2.4428 * * * \\
(0.547)\end{array}$ & $\begin{array}{c}-3.0686^{* * *} \\
(0.811)\end{array}$ \\
\hline Ethnic diversity & $\begin{array}{l}0.0907 \\
(0.106)\end{array}$ & $\begin{array}{l}0.2120 \\
(0.137)\end{array}$ & $\begin{array}{l}-0.0420 \\
(0.127)\end{array}$ & $\begin{array}{l}0.1016 \\
(0.105)\end{array}$ & $\begin{array}{l}0.2157 \\
(0.137)\end{array}$ \\
\hline Population density & $\begin{array}{l}-0.0062 \\
(0.006)\end{array}$ & $\begin{array}{l}-0.0061 \\
(0.006)\end{array}$ & $\begin{array}{l}0.0070 \\
(0.006)\end{array}$ & $\begin{array}{c}-0.0033 \\
(0.006)\end{array}$ & $\begin{array}{l}-0.0031 \\
(0.006)\end{array}$ \\
\hline Total number of orgs. & $\begin{array}{c}-0.0328 * * \\
(0.011)\end{array}$ & $\begin{array}{c}-0.0199 * \\
(0.010)\end{array}$ & $\begin{array}{l}-0.0352 \\
(0.026)\end{array}$ & $\begin{array}{c}-0.0501 * \\
(0.025)\end{array}$ & $\begin{array}{l}-0.0372 \\
(0.024)\end{array}$ \\
\hline$\%$ of pop., age in 20s & $\begin{array}{l}-0.0402 \\
(0.213)\end{array}$ & $\begin{array}{l}0.1206 \\
(0.254)\end{array}$ & $\begin{array}{c}0.5261 * * \\
(0.201)\end{array}$ & $\begin{array}{l}0.0068 \\
(0.215)\end{array}$ & $\begin{array}{l}0.1790 \\
(0.258)\end{array}$ \\
\hline Median rent & $\begin{array}{c}0.1292 * \\
(0.057)\end{array}$ & $\begin{array}{l}0.0712 \\
(0.090)\end{array}$ & $\begin{array}{l}0.0677 \\
(0.051)\end{array}$ & $\begin{array}{l}0.1227 * \\
(0.057)\end{array}$ & $\begin{array}{l}0.0609 \\
(0.090)\end{array}$ \\
\hline Central county & $\begin{array}{l}-0.0067 \\
(0.035)\end{array}$ & $\begin{array}{l}0.0113 \\
(0.037)\end{array}$ & $\begin{array}{r}-0.0227 \\
(0.034)\end{array}$ & $\begin{array}{l}0.0022 \\
(0.037)\end{array}$ & $\begin{array}{l}0.0192 \\
(0.040)\end{array}$ \\
\hline Org. age & $\begin{array}{l}0.0035 \\
(0.006)\end{array}$ & $\begin{array}{l}0.0041 \\
(0.006)\end{array}$ & $\begin{array}{l}0.0044 \\
(0.006)\end{array}$ & $\begin{array}{l}0.0037 \\
(0.006)\end{array}$ & $\begin{array}{l}0.0043 \\
(0.006)\end{array}$ \\
\hline Chain & $\begin{array}{c}-0.2299 * * * \\
(0.052)\end{array}$ & $\begin{array}{c}-0.2318 * * * \\
(0.052)\end{array}$ & $\begin{array}{c}-0.2271 * * * \\
(0.053)\end{array}$ & $\begin{array}{c}-0.2305^{* * *} \\
(0.052)\end{array}$ & $\begin{array}{c}-0.2323 * * * \\
(0.052)\end{array}$ \\
\hline Fast food & $\begin{array}{c}-1.0382 * * * \\
(0.089)\end{array}$ & $\begin{array}{c}-1.0411^{* * *} \\
(0.090)\end{array}$ & $\begin{array}{c}-1.0545^{* * *} \\
(0.090)\end{array}$ & $\begin{array}{c}-1.0414 * * * \\
(0.090)\end{array}$ & $\begin{array}{c}-1.0444 * * * \\
(0.090)\end{array}$ \\
\hline Price=“\$\$” & $\begin{array}{c}0.2975^{* * *} \\
(0.042)\end{array}$ & $\begin{array}{c}0.2982 * * * \\
(0.042)\end{array}$ & $\begin{array}{c}0.2978 * * * \\
(0.042)\end{array}$ & $\begin{array}{c}0.2991 * * * \\
(0.043)\end{array}$ & $\begin{array}{c}0.2994 * * * \\
(0.042)\end{array}$ \\
\hline Price $=“ \$ \$ \$ ”$ & $\begin{array}{l}0.2018 \\
(0.184)\end{array}$ & $\begin{array}{l}0.2087 \\
(0.183)\end{array}$ & $\begin{array}{l}0.2070 \\
(0.184)\end{array}$ & $\begin{array}{l}0.2078 \\
(0.184)\end{array}$ & $\begin{array}{l}0.2133 \\
(0.184)\end{array}$ \\
\hline Price=“\$\$\$\$” & $\begin{array}{c}0.3075^{*} \\
(0.142)\end{array}$ & $\begin{array}{c}0.3047^{*} \\
(0.148)\end{array}$ & $\begin{array}{c}0.2978 * \\
(0.146)\end{array}$ & $\begin{array}{c}0.3134 * \\
(0.146)\end{array}$ & $\begin{array}{c}0.3077^{*} \\
(0.151)\end{array}$ \\
\hline Sunday closed & $\begin{array}{l}0.0248 \\
(0.057)\end{array}$ & $\begin{array}{l}0.0283 \\
(0.057)\end{array}$ & $\begin{array}{l}0.0326 \\
(0.056)\end{array}$ & $\begin{array}{l}0.0233 \\
(0.056)\end{array}$ & $\begin{array}{l}0.0266 \\
(0.056)\end{array}$ \\
\hline Closed before 7pm & $\begin{array}{c}-0.0085 \\
(0.064)\end{array}$ & $\begin{array}{c}-0.0138 \\
(0.065)\end{array}$ & $\begin{array}{c}-0.0103 \\
(0.062)\end{array}$ & $\begin{array}{c}-0.0005 \\
(0.064)\end{array}$ & $\begin{array}{c}-0.0075 \\
(0.064)\end{array}$ \\
\hline Constant & $\begin{array}{l}0.1248 \\
(0.746)\end{array}$ & $\begin{array}{l}-0.2843 \\
(0.961)\end{array}$ & $\begin{array}{c}-2.3652 * * * \\
(0.684)\end{array}$ & $\begin{array}{l}0.3317 \\
(0.770)\end{array}$ & $\begin{array}{c}-0.1318 \\
(0.991)\end{array}$ \\
\hline Fixed Effects, Category (107) & Yes & Yes & Yes & Yes & Yes \\
\hline Number of Cities & 84 & 84 & 84 & 84 & 84 \\
\hline$N$ & 4,534 & 4,534 & 4,534 & 4,534 & 4,534 \\
\hline Log-pseudo-likelihood & -2892.98 & -2892.95 & -2895.14 & -4119.80 & -4120.14 \\
\hline
\end{tabular}

Robust standard errors clustered by city in parentheses; ${ }^{+} p<0.10$; ${ }^{*} p<0.05 ;{ }^{* *} p<0.01$; *** $p<0.001$.

$T$-tests were one-tailed for hypothesized effects and two-tailed for control variables. 
Table 5. GLM Regression Predicting Product-level Spanning (H3, H4)

\begin{tabular}{|c|c|c|c|c|c|c|}
\hline & Model 12 & Model 13 & Model 14 & Model 15 & Model 16 & Model 17 \\
\hline Income & & $\begin{array}{l}-0.0013 \\
(0.011)\end{array}$ & & $\begin{array}{c}-0.0297 * \\
(0.016)\end{array}$ & & $\begin{array}{l}-0.0080 \\
(0.014)\end{array}$ \\
\hline Education & & & $\begin{array}{c}0.2222+ \\
(0.148)\end{array}$ & $\begin{array}{c}0.4362 * \\
(0.197)\end{array}$ & & \\
\hline Bachelor's & & & & & $\begin{array}{l}0.1150 \\
(0.351)\end{array}$ & $\begin{array}{l}0.1500 \\
(0.358)\end{array}$ \\
\hline Master's & & & & & $\begin{array}{l}0.1050 \\
(0.292)\end{array}$ & $\begin{array}{l}0.2053 \\
(0.341)\end{array}$ \\
\hline PhD & & & & & $\begin{array}{l}1.6201^{*} \\
(0.764)\end{array}$ & $\begin{array}{l}1.5597 * \\
(0.762)\end{array}$ \\
\hline Org.-level spanning & $\begin{array}{c}0.1271 * * * \\
(0.032)\end{array}$ & $\begin{array}{c}0.1271 * * * \\
(0.032)\end{array}$ & $\begin{array}{c}0.1261 * * * \\
(0.032)\end{array}$ & $\begin{array}{c}0.1250 * * * \\
(0.032)\end{array}$ & $\begin{array}{c}0.1240 * * * \\
(0.032)\end{array}$ & $\begin{array}{c}0.1240 * * * \\
(0.032)\end{array}$ \\
\hline Income diversity & $\begin{array}{c}-1.2151^{* * *} \\
(0.363)\end{array}$ & $\begin{array}{c}-1.2830+ \\
(0.757)\end{array}$ & $\begin{array}{l}-0.7399 \\
(0.470)\end{array}$ & $\begin{array}{c}-1.7983^{* *} \\
(0.697)\end{array}$ & $\begin{array}{c}-0.6352+ \\
(0.386)\end{array}$ & $\begin{array}{l}-0.9886 \\
(0.731)\end{array}$ \\
\hline Education diversity & $\begin{array}{l}0.5872 \\
(0.575)\end{array}$ & $\begin{array}{l}0.5909 \\
(0.576)\end{array}$ & $\begin{array}{l}0.0562 \\
(0.669)\end{array}$ & $\begin{array}{l}-0.3740 \\
(0.660)\end{array}$ & $\begin{array}{l}-0.8389 \\
(0.786)\end{array}$ & $\begin{array}{l}-0.8505 \\
(0.775)\end{array}$ \\
\hline Ethnic diversity & $\begin{array}{l}-0.1615 \\
(0.125)\end{array}$ & $\begin{array}{r}-0.1636 \\
(0.127)\end{array}$ & $\begin{array}{l}-0.0983 \\
(0.120)\end{array}$ & $\begin{array}{l}-0.0828 \\
(0.108)\end{array}$ & $\begin{array}{r}-0.0220 \\
(0.122)\end{array}$ & $\begin{array}{l}-0.0271 \\
(0.120)\end{array}$ \\
\hline Population density & $\begin{array}{r}-0.0022 \\
(0.005)\end{array}$ & $\begin{array}{l}-0.0023 \\
(0.005)\end{array}$ & $\begin{array}{l}-0.0032 \\
(0.005)\end{array}$ & $\begin{array}{l}-0.0063 \\
(0.005)\end{array}$ & $\begin{array}{l}-0.0039 \\
(0.005)\end{array}$ & $\begin{array}{l}-0.0048 \\
(0.005)\end{array}$ \\
\hline Total number of orgs. & $\begin{array}{c}0.0384^{* * *} \\
(0.008)\end{array}$ & $\begin{array}{c}0.0388 * * * \\
(0.009)\end{array}$ & $\begin{array}{c}0.0270^{* *} \\
(0.010)\end{array}$ & $\begin{array}{c}0.0269 * * \\
(0.009)\end{array}$ & $\begin{array}{c}0.0340 * * * \\
(0.009)\end{array}$ & $\begin{array}{c}0.0346 * * * \\
(0.009)\end{array}$ \\
\hline$\%$ of pop., age in $20 \mathrm{~s}$ & $\begin{array}{l}0.0346 \\
(0.166)\end{array}$ & $\begin{array}{l}0.0194 \\
(0.186)\end{array}$ & $\begin{array}{l}0.1028 \\
(0.150)\end{array}$ & $\begin{array}{l}-0.1696 \\
(0.202)\end{array}$ & $\begin{array}{l}0.0772 \\
(0.153)\end{array}$ & $\begin{array}{l}-0.0064 \\
(0.185)\end{array}$ \\
\hline Median rent & $\begin{array}{l}-0.0080 \\
(0.051)\end{array}$ & $\begin{array}{r}-0.0052 \\
(0.047)\end{array}$ & $\begin{array}{l}-0.0261 \\
(0.049)\end{array}$ & $\begin{array}{l}0.0202 \\
(0.048)\end{array}$ & $\begin{array}{l}-0.0379 \\
(0.054)\end{array}$ & $\begin{array}{l}-0.0287 \\
(0.053)\end{array}$ \\
\hline DC & $\begin{array}{c}-0.3243^{* *} \\
(0.106)\end{array}$ & $\begin{array}{c}-0.3314 * * \\
(0.123)\end{array}$ & $\begin{array}{l}-0.1568 \\
(0.138)\end{array}$ & $\begin{array}{l}-0.1542 \\
(0.134)\end{array}$ & $\begin{array}{c}-0.2309+ \\
(0.127)\end{array}$ & $\begin{array}{c}-0.2408+ \\
(0.124)\end{array}$ \\
\hline Central county & $\begin{array}{l}0.0263 \\
(0.034)\end{array}$ & $\begin{array}{l}0.0276 \\
(0.036)\end{array}$ & $\begin{array}{l}0.0160 \\
(0.034)\end{array}$ & $\begin{array}{l}0.0337 \\
(0.037)\end{array}$ & $\begin{array}{l}0.0371 \\
(0.034)\end{array}$ & $\begin{array}{l}0.0418 \\
(0.036)\end{array}$ \\
\hline Org. age & $\begin{array}{r}-0.0012 \\
(0.010)\end{array}$ & $\begin{array}{r}-0.0012 \\
(0.010)\end{array}$ & $\begin{array}{l}-0.0018 \\
(0.010)\end{array}$ & $\begin{array}{l}-0.0018 \\
(0.010)\end{array}$ & $\begin{array}{r}-0.0017 \\
(0.010)\end{array}$ & $\begin{array}{r}-0.0017 \\
(0.010)\end{array}$ \\
\hline Chain & $\begin{array}{c}-0.4400 * * * \\
(0.034)\end{array}$ & $\begin{array}{c}-0.4400 * * * \\
(0.034)\end{array}$ & $\begin{array}{c}-0.4393 * * * \\
(0.034)\end{array}$ & $\begin{array}{c}-0.4394 * * * \\
(0.034)\end{array}$ & $\begin{array}{c}-0.4396 * * * \\
(0.034)\end{array}$ & $\begin{array}{c}-0.4397 * * * \\
(0.034)\end{array}$ \\
\hline Fast food & $\begin{array}{c}-0.2497 * * * \\
(0.057)\end{array}$ & $\begin{array}{c}-0.2498 * * * \\
(0.057)\end{array}$ & $\begin{array}{c}-0.2484^{* * *} \\
(0.057)\end{array}$ & $\begin{array}{c}-0.2490 * * * \\
(0.057)\end{array}$ & $\begin{array}{l}-0.2481^{* * *} \\
(0.057)\end{array}$ & $\begin{array}{l}-0.2486 * * * \\
(0.057)\end{array}$ \\
\hline Price=“\$\$” & $\begin{array}{c}-0.1760 * * * \\
(0.037)\end{array}$ & $\begin{array}{c}-0.1760 * * * \\
(0.037)\end{array}$ & $\begin{array}{l}-0.1766 * * * \\
(0.037)\end{array}$ & $\begin{array}{c}-0.1756 * * * \\
(0.037)\end{array}$ & $\begin{array}{c}-0.1750 * * * \\
(0.037)\end{array}$ & $\begin{array}{c}-0.1748 * * * \\
(0.037)\end{array}$ \\
\hline Price $=“ \$ \$ \$ ”$ & $\begin{array}{c}0.0918 * * \\
(0.035)\end{array}$ & $\begin{array}{c}0.0919 * * \\
(0.035)\end{array}$ & $\begin{array}{c}0.0893^{* *} \\
(0.034)\end{array}$ & $\begin{array}{c}0.0886^{* *} \\
(0.034)\end{array}$ & $\begin{array}{c}0.0886^{* *} \\
(0.034)\end{array}$ & $\begin{array}{c}0.0890 * * \\
(0.034)\end{array}$ \\
\hline Price $=“ \$ \$ \$ \$ ”$ & $\begin{array}{c}0.4239 * * * \\
(0.076)\end{array}$ & $\begin{array}{c}0.4240 * * * \\
(0.077)\end{array}$ & $\begin{array}{c}0.4231 * * * \\
(0.075)\end{array}$ & $\begin{array}{c}0.4230 * * * \\
(0.075)\end{array}$ & $\begin{array}{c}0.4223 * * * \\
(0.075)\end{array}$ & $\begin{array}{c}0.4224 * * * \\
(0.075)\end{array}$ \\
\hline Closed before 7pm & $\begin{array}{c}-0.0578 \\
(0.038)\end{array}$ & $\begin{array}{l}-0.0577 \\
(0.038)\end{array}$ & $\begin{array}{l}-0.0592 \\
(0.038)\end{array}$ & $\begin{array}{c}-0.0584 \\
(0.038)\end{array}$ & $\begin{array}{l}-0.0579 \\
(0.038)\end{array}$ & $\begin{array}{l}-0.0577 \\
(0.038)\end{array}$ \\
\hline Only lunch & $\begin{array}{c}0.2293^{* * *} * \\
(0.030)\end{array}$ & $\begin{array}{c}0.2292 * * * \\
(0.030)\end{array}$ & $\begin{array}{c}0.2302^{* * *} \\
(0.030)\end{array}$ & $\begin{array}{c}0.2297 * * * \\
(0.030)\end{array}$ & $\begin{array}{c}0.2287 * * * \\
(0.030)\end{array}$ & $\begin{array}{c}0.2286^{* * * *} \\
(0.030)\end{array}$ \\
\hline Constant & $\begin{array}{c}1.8157 * * * \\
(0.489)\end{array}$ & $\begin{array}{l}1.8836 * \\
(0.798)\end{array}$ & $\begin{array}{c}1.7099 * * * \\
(0.475)\end{array}$ & $\begin{array}{c}3.1248 * * * \\
(0.876)\end{array}$ & $\begin{array}{c}2.2789 * * * \\
(0.565)\end{array}$ & $\begin{array}{c}2.6565^{* *} \\
(0.898)\end{array}$ \\
\hline $\begin{array}{l}\text { Fixed Effects, Category } \\
\text { (107) }\end{array}$ & Yes & Yes & Yes & Yes & Yes & Yes \\
\hline Number of Cities & 85 & 85 & 85 & 85 & 85 & 85 \\
\hline$N$ & 6,072 & 6,072 & 6,072 & 6,072 & 6,072 & 6,072 \\
\hline Log-pseudo-likelihood & -2505.10 & -2505.10 & -2504.96 & -2311.37 & -2504.91 & -2504.76 \\
\hline
\end{tabular}

Robust standard errors clustered by city in parentheses; ${ }^{+} p<0.10 ; * p<0.05 ;{ }^{* *} p<0.01 ; * * * p<0.001$.

$T$-tests were one-tailed for hypothesized effects and two-tailed for control variables. 
Table 6. GLM Regression Predicting Product-level Spanning (Robustness Check)

\begin{tabular}{|c|c|c|c|c|c|}
\hline & Model 18 & Model 19 & Model 20 & Model 21 & Model 22 \\
\hline Income & $\begin{array}{c}-0.0338 * \\
(0.016)\end{array}$ & $\begin{array}{l}-0.0118 \\
(0.014)\end{array}$ & & $\begin{array}{c}-0.0352^{*} \\
(0.017)\end{array}$ & $\begin{array}{l}-0.0157 \\
(0.015)\end{array}$ \\
\hline Education & $\begin{array}{c}0.3966^{*} \\
(0.190)\end{array}$ & & & $\begin{array}{l}0.3777^{*} \\
(0.209)\end{array}$ & \\
\hline Bachelor's & & $\begin{array}{l}0.1161 \\
(0.346)\end{array}$ & & & $\begin{array}{l}0.0357 \\
(0.360)\end{array}$ \\
\hline Master's & & $\begin{array}{l}0.1224 \\
(0.340)\end{array}$ & & & $(0.379)$ \\
\hline PhD & & $\begin{array}{l}1.5764 * \\
(0.799)\end{array}$ & & & $\begin{array}{l}1.4059+ \\
(0.907)\end{array}$ \\
\hline \# of orgs. in category & & & $\begin{array}{c}-1.3136 * * * \\
(0.300)\end{array}$ & $\begin{array}{c}-1.3085^{* * *} \\
(0.293)\end{array}$ & $\begin{array}{c}-1.3225^{* * *} \\
(0.298)\end{array}$ \\
\hline (\# of orgs. in category) $^{2}$ & & & $\begin{array}{c}1.0868 * * \\
(0.395)\end{array}$ & $\begin{array}{c}1.0757 * * \\
(0.391)\end{array}$ & $\begin{array}{c}1.1104^{* *} \\
(0.391)\end{array}$ \\
\hline Org.-level spanning & $\begin{array}{c}0.1156^{*} \\
(0.045)\end{array}$ & $\begin{array}{c}0.1142 * \\
(0.045)\end{array}$ & $\begin{array}{c}0.1162 * \\
(0.046)\end{array}$ & $\begin{array}{c}0.1137 * \\
(0.046)\end{array}$ & $\begin{array}{c}0.1124^{*} \\
(0.046)\end{array}$ \\
\hline Income diversity & $\begin{array}{c}-2.0903^{* *} \\
(0.680)\end{array}$ & $\begin{array}{c}-1.2338+ \\
(0.704)\end{array}$ & $\begin{array}{c}-1.1363^{* *} \\
(0.359)\end{array}$ & $\begin{array}{c}-2.1305^{* *} \\
(0.744)\end{array}$ & $\begin{array}{c}-1.3312+ \\
(0.768)\end{array}$ \\
\hline Education diversity & $\begin{array}{l}-0.4080 \\
(0.617)\end{array}$ & $\begin{array}{l}-0.9215 \\
(0.741)\end{array}$ & $\begin{array}{l}0.9374 \\
(0.628)\end{array}$ & $\begin{array}{l}0.1264 \\
(0.645)\end{array}$ & $\begin{array}{l}-0.3570 \\
(0.794)\end{array}$ \\
\hline Ethnic diversity & $\begin{array}{c}-0.0963 \\
(0.106)\end{array}$ & $\begin{array}{c}-0.0379 \\
(0.118)\end{array}$ & $\begin{array}{c}-0.1349 \\
(0.131)\end{array}$ & $\begin{array}{r}-0.0807 \\
(0.110)\end{array}$ & $\begin{array}{r}-0.0202 \\
(0.119)\end{array}$ \\
\hline Population density & $\begin{array}{l}-0.0083 \\
(0.005)\end{array}$ & $\begin{array}{l}-0.0066 \\
(0.005)\end{array}$ & $\begin{array}{l}-0.0084 \\
(0.006)\end{array}$ & $\begin{array}{c}-0.0126^{*} \\
(0.006)\end{array}$ & $\begin{array}{c}-0.0115+ \\
(0.006)\end{array}$ \\
\hline Total number of orgs. & $\begin{array}{c}0.0294 * * \\
(0.009)\end{array}$ & $\begin{array}{c}0.0370 * * * \\
(0.009)\end{array}$ & $\begin{array}{c}0.0965 * * * \\
(0.014)\end{array}$ & $\begin{array}{c}0.0902 * * * \\
(0.015)\end{array}$ & $\begin{array}{c}0.0968 * * * \\
(0.015)\end{array}$ \\
\hline$\%$ of pop., age in 20 s & $\begin{array}{l}-0.1571 \\
(0.207)\end{array}$ & $\begin{array}{l}0.0154 \\
(0.194)\end{array}$ & $\begin{array}{l}0.1044 \\
(0.226)\end{array}$ & $\begin{array}{l}-0.1807 \\
(0.253)\end{array}$ & $\begin{array}{l}-0.0402 \\
(0.236)\end{array}$ \\
\hline Median rent & $\begin{array}{l}0.0190 \\
(0.050)\end{array}$ & $\begin{array}{l}-0.0264 \\
(0.054)\end{array}$ & $\begin{array}{l}-0.0206 \\
(0.055)\end{array}$ & $\begin{array}{l}0.0238 \\
(0.051)\end{array}$ & $\begin{array}{l}-0.0134 \\
(0.054)\end{array}$ \\
\hline Central county & $\begin{array}{l}0.0373 \\
(0.036)\end{array}$ & $\begin{array}{l}0.0454 \\
(0.035)\end{array}$ & $\begin{array}{l}0.0092 \\
(0.033)\end{array}$ & $\begin{array}{l}0.0244 \\
(0.037)\end{array}$ & $\begin{array}{l}0.0312 \\
(0.036)\end{array}$ \\
\hline Org. age & $\begin{array}{l}0.0106 \\
(0.008)\end{array}$ & $\begin{array}{l}0.0108 \\
(0.008)\end{array}$ & $\begin{array}{l}0.0105 \\
(0.008)\end{array}$ & $\begin{array}{l}0.0101 \\
(0.008)\end{array}$ & $\begin{array}{l}0.0103 \\
(0.008)\end{array}$ \\
\hline Chain & $\begin{array}{c}-0.4002 * * * \\
(0.025)\end{array}$ & $\begin{array}{c}-0.4003 * * * \\
(0.025)\end{array}$ & $\begin{array}{c}-0.4007 * * * \\
(0.025)\end{array}$ & $\begin{array}{c}-0.4004 * * * \\
(0.025)\end{array}$ & $\begin{array}{c}-0.4005 * * * \\
(0.025)\end{array}$ \\
\hline Fast food & $\begin{array}{c}-0.2974 * * * \\
(0.047)\end{array}$ & $\begin{array}{c}-0.2965 * * * \\
(0.048)\end{array}$ & $\begin{array}{c}-0.2924 * * * \\
(0.048)\end{array}$ & $\begin{array}{c}-0.2927 * * * \\
(0.048)\end{array}$ & $\begin{array}{c}-0.2921^{* * * *} \\
(0.049)\end{array}$ \\
\hline Price $=“ \$ \$ ”$ & $\begin{array}{c}-0.1425^{* *} \\
(0.048)\end{array}$ & $\begin{array}{c}-0.1413^{* *} \\
(0.048)\end{array}$ & $\begin{array}{c}-0.1479 * * \\
(0.048)\end{array}$ & $\begin{array}{c}-0.1468 * * \\
(0.048)\end{array}$ & $\begin{array}{c}-0.1455 * * \\
(0.047)\end{array}$ \\
\hline Price=“\$\$\$” & $\begin{array}{l}0.0844 \\
(0.055)\end{array}$ & $\begin{array}{l}0.0846 \\
(0.055)\end{array}$ & $\begin{array}{c}0.0951+ \\
(0.055)\end{array}$ & $\begin{array}{c}0.0911+ \\
(0.054)\end{array}$ & $\begin{array}{c}0.0925+ \\
(0.054)\end{array}$ \\
\hline Price=“\$\$\$\$” & $\begin{array}{c}0.5008 * * * \\
(0.116)\end{array}$ & $\begin{array}{c}0.4997 * * * \\
(0.117)\end{array}$ & $\begin{array}{c}0.4976 * * * \\
(0.118)\end{array}$ & $\begin{array}{c}0.4942 * * * \\
(0.116)\end{array}$ & $\begin{array}{c}0.4947 * * * \\
(0.116)\end{array}$ \\
\hline Sunday closed & $\begin{array}{c}-0.0970 * \\
(0.039)\end{array}$ & $\begin{array}{c}-0.0955^{*} \\
(0.039)\end{array}$ & $\begin{array}{c}-0.1028^{*} \\
(0.040)\end{array}$ & $\begin{array}{c}-0.1030 * \\
(0.040)\end{array}$ & $\begin{array}{c}-0.1013^{*} \\
(0.040)\end{array}$ \\
\hline Closed before $7 \mathrm{pm}$ & $\begin{array}{l}0.1752^{*} \\
(0.085)\end{array}$ & $\begin{array}{l}0.1725^{*} \\
(0.086)\end{array}$ & $\begin{array}{l}0.1779 * \\
(0.086)\end{array}$ & $\begin{array}{l}0.1768 * \\
(0.086)\end{array}$ & $\begin{array}{l}0.1743^{*} \\
(0.086)\end{array}$ \\
\hline Constant & $\begin{array}{c}3.3497 * * * \\
(0.842)\end{array}$ & $\begin{array}{c}2.8570 * * * \\
(0.855)\end{array}$ & $\begin{array}{c}1.3777 * * \\
(0.498)\end{array}$ & $\begin{array}{c}3.0027^{* *} \\
(0.919)\end{array}$ & $\begin{array}{c}2.5552^{* *} \\
(0.915)\end{array}$ \\
\hline Fixed Effects, Category (107) & Yes & Yes & Yes & Yes & Yes \\
\hline Number of Cities & 84 & 84 & 84 & 84 & 84 \\
\hline$N$ & 4,534 & 4,534 & 4,534 & 4,534 & 4,534 \\
\hline Log-pseudo-likelihood & -1918.24 & -1918.15 & -1917.09 & -1916.84 & -1916.76 \\
\hline
\end{tabular}

Robust standard errors clustered by city in parentheses; ${ }^{+} p<0.10$; ${ }^{*} p<0.05 ;{ }^{* *} p<0.01$; ${ }^{* * *} p<0.001$.

$T$-tests were one-tailed for hypothesized effects and two-tailed for control variables. 
Table 7. GLM Regression Predicting Organization-level Spanning (H5)

\begin{tabular}{|c|c|c|c|c|c|}
\hline & Model 23 & Model 24 & Model 25 & Model 26 & Model 27 \\
\hline Income & & & & $\begin{array}{c}-0.0681 * * * \\
(0.015)\end{array}$ & $\begin{array}{c}-0.0359+ \\
(0.023)\end{array}$ \\
\hline Education & & & & $\begin{array}{c}0.7907 * * * \\
(0.147)\end{array}$ & \\
\hline Bachelor's & & & & & $\begin{array}{l}-0.1658 \\
(0.325)\end{array}$ \\
\hline Master's & & & & & $\begin{array}{c}1.0091^{* *} \\
(0.418)\end{array}$ \\
\hline PhD & & & & & $\begin{array}{c}2.0087 * * \\
(0.670)\end{array}$ \\
\hline \# of orgs. in category & & $\begin{array}{c}-0.0663+ \\
(0.044)\end{array}$ & $\begin{array}{c}0.3074 * * \\
(0.113)\end{array}$ & $\begin{array}{c}0.2993 * * \\
(0.113)\end{array}$ & $\begin{array}{c}0.3011^{* *} \\
(0.112)\end{array}$ \\
\hline (\# of orgs. in category) $^{2}$ & & & $\begin{array}{c}-0.1198 * * * \\
(0.026)\end{array}$ & $\begin{array}{c}-0.1175^{* * *} \\
(0.026)\end{array}$ & $\begin{array}{c}-0.1180 * * * \\
(0.026)\end{array}$ \\
\hline Income diversity & $\begin{array}{l}-0.1459 \\
(0.340)\end{array}$ & $\begin{array}{l}-0.1680 \\
(0.336)\end{array}$ & $\begin{array}{l}-0.1532 \\
(0.339)\end{array}$ & $\begin{array}{c}-1.8726^{* *} \\
(0.716)\end{array}$ & $\begin{array}{l}-0.6903 \\
(0.924)\end{array}$ \\
\hline Education diversity & $\begin{array}{l}-0.4871 \\
(0.728)\end{array}$ & $\begin{array}{l}-0.4757 \\
(0.714)\end{array}$ & $\begin{array}{l}-0.5583 \\
(0.719)\end{array}$ & $\begin{array}{c}-2.1337 * * * \\
(0.537)\end{array}$ & $\begin{array}{c}-2.9624 * * * \\
(0.803)\end{array}$ \\
\hline Ethnic diversity & $\begin{array}{l}-0.0316 \\
(0.139)\end{array}$ & $\begin{array}{l}-0.0313 \\
(0.138)\end{array}$ & $\begin{array}{l}-0.0402 \\
(0.138)\end{array}$ & $\begin{array}{l}0.0808 \\
(0.110)\end{array}$ & $\begin{array}{c}0.2234+ \\
(0.135)\end{array}$ \\
\hline Population density & $\begin{array}{l}0.0039 \\
(0.007)\end{array}$ & $\begin{array}{l}0.0038 \\
(0.007)\end{array}$ & $\begin{array}{l}0.0044 \\
(0.007)\end{array}$ & $\begin{array}{c}-0.0059 \\
(0.007)\end{array}$ & $\begin{array}{r}-0.0052 \\
(0.006)\end{array}$ \\
\hline Total number of orgs. & $\begin{array}{l}-0.0127 \\
(0.011)\end{array}$ & $\begin{array}{c}-0.0073 \\
(0.011)\end{array}$ & $\begin{array}{c}-0.0320 * \\
(0.013)\end{array}$ & $\begin{array}{c}-0.0441^{* *} \\
(0.014)\end{array}$ & $\begin{array}{c}-0.0302 * \\
(0.013)\end{array}$ \\
\hline$\%$ of pop., age in 20 s & $\begin{array}{l}0.3422 \\
(0.235)\end{array}$ & $\begin{array}{l}0.3597 \\
(0.232)\end{array}$ & $\begin{array}{l}0.3450 \\
(0.232)\end{array}$ & $\begin{array}{l}-0.2402 \\
(0.276)\end{array}$ & $\begin{array}{l}-0.0248 \\
(0.286)\end{array}$ \\
\hline Median rent & $\begin{array}{l}0.0457 \\
(0.055)\end{array}$ & $\begin{array}{l}0.0421 \\
(0.055)\end{array}$ & $\begin{array}{l}0.0468 \\
(0.054)\end{array}$ & $\begin{array}{c}0.1163+ \\
(0.067)\end{array}$ & $\begin{array}{l}0.0568 \\
(0.093)\end{array}$ \\
\hline DC & $\begin{array}{l}0.1853 \\
(0.149)\end{array}$ & $\begin{array}{l}0.1834 \\
(0.147)\end{array}$ & $\begin{array}{l}0.3830 * \\
(0.155)\end{array}$ & $\begin{array}{c}0.5672 * * \\
(0.178)\end{array}$ & $\begin{array}{l}0.4011 * \\
(0.161)\end{array}$ \\
\hline Central county & $\begin{array}{l}-0.0067 \\
(0.038)\end{array}$ & $\begin{array}{l}-0.0081 \\
(0.037)\end{array}$ & $\begin{array}{l}-0.0019 \\
(0.038)\end{array}$ & $\begin{array}{l}0.0304 \\
(0.043)\end{array}$ & $\begin{array}{l}0.0483 \\
(0.044)\end{array}$ \\
\hline Org. age & $\begin{array}{c}-0.0023 \\
(0.005)\end{array}$ & $\begin{array}{l}-0.0025 \\
(0.005)\end{array}$ & $\begin{array}{c}-0.0022 \\
(0.005)\end{array}$ & $\begin{array}{c}-0.0024 \\
(0.005)\end{array}$ & $\begin{array}{c}-0.0020 \\
(0.005)\end{array}$ \\
\hline Chain & $\begin{array}{c}-0.2603 * * * \\
(0.041)\end{array}$ & $\begin{array}{c}-0.2570 * * * \\
(0.041)\end{array}$ & $\begin{array}{c}-0.2545^{* * *} \\
(0.040)\end{array}$ & $\begin{array}{c}-0.2573 * * * \\
(0.039)\end{array}$ & $\begin{array}{c}-0.2592^{* * *} \\
(0.039)\end{array}$ \\
\hline Fast food & $\begin{array}{c}-1.1071 * * * \\
(0.072)\end{array}$ & $\begin{array}{c}-1.1060 * * * \\
(0.072)\end{array}$ & $\begin{array}{c}-1.1089 * * * \\
(0.070)\end{array}$ & $\begin{array}{c}-1.0992 * * * \\
(0.070)\end{array}$ & $\begin{array}{c}-1.1005^{* * * *} \\
(0.070)\end{array}$ \\
\hline Price=" $\$ \$ "$ & $\begin{array}{c}0.1829 * * \\
(0.067)\end{array}$ & $\begin{array}{c}0.1865 * * \\
(0.069)\end{array}$ & $\begin{array}{c}0.1871^{* *} \\
(0.069)\end{array}$ & $\begin{array}{c}0.1886^{* *} \\
(0.069)\end{array}$ & $\begin{array}{c}0.1886^{* *} \\
(0.069)\end{array}$ \\
\hline Price=“\$\$\$” & $\begin{array}{l}0.1456 \\
(0.125)\end{array}$ & $\begin{array}{l}0.1414 \\
(0.125)\end{array}$ & $\begin{array}{l}0.1410 \\
(0.125)\end{array}$ & $\begin{array}{c}0.1433 \\
(0.123)\end{array}$ & $\begin{array}{l}0.1464 \\
(0.123)\end{array}$ \\
\hline Price=“\$\$\$\$” & $\begin{array}{c}0.3350 * * * \\
(0.074)\end{array}$ & $\begin{array}{c}0.3329 * * * \\
(0.072)\end{array}$ & $\begin{array}{c}0.3242 * * * \\
(0.074)\end{array}$ & $\begin{array}{c}0.3330 * * * \\
(0.074)\end{array}$ & $\begin{array}{c}0.3294 * * * \\
(0.077)\end{array}$ \\
\hline Sunday closed & $\begin{array}{l}0.0174 \\
(0.032)\end{array}$ & $\begin{array}{l}0.0243 \\
(0.031)\end{array}$ & $\begin{array}{l}0.0366 \\
(0.029)\end{array}$ & $\begin{array}{l}0.0327 \\
(0.029)\end{array}$ & $\begin{array}{l}0.0333 \\
(0.029)\end{array}$ \\
\hline Closed before 7pm & $\begin{array}{l}0.0229 \\
(0.031)\end{array}$ & $\begin{array}{l}0.0298 \\
(0.028)\end{array}$ & $\begin{array}{l}0.0318 \\
(0.030)\end{array}$ & $\begin{array}{l}0.0352 \\
(0.029)\end{array}$ & $\begin{array}{l}0.0327 \\
(0.029)\end{array}$ \\
\hline Constant & $\begin{array}{c}-2.3240 * * * \\
(0.686)\end{array}$ & $\begin{array}{c}-2.3284 * * * \\
(0.676)\end{array}$ & $\begin{array}{c}-2.2742^{* * * *} \\
(0.690)\end{array}$ & $\begin{array}{l}0.6877 \\
(0.852)\end{array}$ & $\begin{array}{l}0.1243 \\
(1.080)\end{array}$ \\
\hline Fixed Effects, Category (107) & Yes & Yes & Yes & Yes & Yes \\
\hline Number of Cities & 85 & 85 & 85 & 85 & 85 \\
\hline$N$ & 6,072 & 6,072 & 6,072 & 6,072 & 6,072 \\
\hline Log-pseudo-likelihood & -4126.18 & -4125.25 & -4122.64 & -4119.80 & -4120.14 \\
\hline
\end{tabular}

Robust standard errors clustered by city in parentheses; ${ }^{+} p<0.10 ;{ }^{*} p<0.05 ;{ }^{* *} p<0.01 ;{ }^{* * *} p<0.001$.

$T$-tests were one-tailed for hypothesized effects and two-tailed for control variables. 
Table 8. GLM Regression Predicting Product-level Spanning (H6)

\begin{tabular}{|c|c|c|c|c|c|}
\hline & Model 28 & Model 29 & Model 30 & Model 31 & Model 32 \\
\hline Income & & & & $\begin{array}{l}-0.0301^{*} \\
(0.016)\end{array}$ & $\begin{array}{l}-0.0103 \\
(0.015)\end{array}$ \\
\hline Education & & & & $\begin{array}{l}0.4206^{*} \\
(0.201)\end{array}$ & \\
\hline Bachelor's & & & & & $\begin{array}{l}0.1254 \\
(0.359)\end{array}$ \\
\hline Master's & & & & & $\begin{array}{l}0.2552 \\
(0.353)\end{array}$ \\
\hline PhD & & & & & $\begin{array}{l}1.4024^{*} \\
(0.799)\end{array}$ \\
\hline \# of orgs. in category & & $\begin{array}{c}-0.1587 * * * \\
(0.023)\end{array}$ & $\begin{array}{c}-0.5359 * * * \\
(0.087)\end{array}$ & $\begin{array}{c}-0.5348 * * * \\
(0.087)\end{array}$ & $\begin{array}{l}-0.5318^{* * *} \\
\quad(0.088)\end{array}$ \\
\hline (\# of orgs. in category) $^{2}$ & & & $\begin{array}{c}0.1248 * * * \\
(0.024)\end{array}$ & $\begin{array}{c}0.1247 * * * \\
(0.023)\end{array}$ & $\begin{array}{c}0.1240 * * * \\
(0.024)\end{array}$ \\
\hline Org.-level spanning & $\begin{array}{c}0.1271^{* * *} \\
(0.032)\end{array}$ & $\begin{array}{c}0.1267 * * * \\
(0.032)\end{array}$ & $\begin{array}{c}0.1290 * * * \\
(0.033)\end{array}$ & $\begin{array}{c}0.1270 * * * \\
(0.033)\end{array}$ & $\begin{array}{c}0.1261^{* * *} \\
(0.034)\end{array}$ \\
\hline Income diversity & $\begin{array}{c}-1.2151^{* * *} \\
(0.363)\end{array}$ & $\begin{array}{c}-1.2266 * * * \\
(0.360)\end{array}$ & $\begin{array}{c}-1.2137 * * * \\
(0.357)\end{array}$ & $\begin{array}{c}-1.8528^{*} \\
(0.728)\end{array}$ & $\begin{array}{l}-1.1207 \\
(0.766)\end{array}$ \\
\hline Education diversity & $\begin{array}{l}0.5872 \\
(0.575)\end{array}$ & $\begin{array}{l}0.6628 \\
(0.580)\end{array}$ & $\begin{array}{l}0.7689 \\
(0.589)\end{array}$ & $\begin{array}{l}-0.1548 \\
(0.656)\end{array}$ & $\begin{array}{l}-0.5686 \\
(0.791)\end{array}$ \\
\hline Ethnic diversity & $\begin{array}{c}-0.1615 \\
(0.125)\end{array}$ & $\begin{array}{c}-0.1598 \\
(0.124)\end{array}$ & $\begin{array}{l}-0.1462 \\
(0.124)\end{array}$ & $\begin{array}{c}-0.0725 \\
(0.107)\end{array}$ & $\begin{array}{c}-0.0218 \\
(0.120)\end{array}$ \\
\hline Population density & $\begin{array}{l}-0.0022 \\
(0.005)\end{array}$ & $\begin{array}{l}-0.0027 \\
(0.005)\end{array}$ & $\begin{array}{l}-0.0034 \\
(0.006)\end{array}$ & $\begin{array}{l}-0.0074 \\
(0.006)\end{array}$ & $\begin{array}{l}-0.0062 \\
(0.006)\end{array}$ \\
\hline Total number of orgs. & $\begin{array}{c}0.0384 * * * \\
(0.008)\end{array}$ & $\begin{array}{c}0.0520 * * * \\
(0.007)\end{array}$ & $\begin{array}{c}0.0770 * * * \\
(0.009)\end{array}$ & $\begin{array}{c}0.0664 * * * \\
(0.010)\end{array}$ & $\begin{array}{c}0.0735^{* * *} \\
(0.010)\end{array}$ \\
\hline$\%$ of pop., age in 20s & $\begin{array}{l}0.0346 \\
(0.166)\end{array}$ & $\begin{array}{l}0.0345 \\
(0.170)\end{array}$ & $\begin{array}{l}0.0322 \\
(0.186)\end{array}$ & $\begin{array}{l}-0.1815 \\
(0.217)\end{array}$ & $\begin{array}{l}-0.0383 \\
(0.202)\end{array}$ \\
\hline Median rent & $\begin{array}{c}-0.0080 \\
(0.051)\end{array}$ & $\begin{array}{c}-0.0129 \\
(0.051)\end{array}$ & $\begin{array}{c}-0.0176 \\
(0.052)\end{array}$ & $\begin{array}{l}0.0127 \\
(0.048)\end{array}$ & $\begin{array}{c}-0.0319 \\
(0.053)\end{array}$ \\
\hline DC & $\begin{array}{c}-0.3243 * * \\
(0.106)\end{array}$ & $\begin{array}{c}-0.3564 * * * \\
(0.106)\end{array}$ & $\begin{array}{c}-0.5659 * * * \\
(0.105)\end{array}$ & $\begin{array}{c}-0.4094^{* *} \\
(0.134)\end{array}$ & $\begin{array}{c}-0.4911^{* * * *} \\
(0.130)\end{array}$ \\
\hline Central county & $\begin{array}{l}0.0263 \\
(0.034)\end{array}$ & $\begin{array}{l}0.0259 \\
(0.034)\end{array}$ & $\begin{array}{l}0.0217 \\
(0.034)\end{array}$ & $\begin{array}{l}0.0301 \\
(0.038)\end{array}$ & $\begin{array}{l}0.0374 \\
(0.037)\end{array}$ \\
\hline Org. age & $\begin{array}{r}-0.0012 \\
(0.010)\end{array}$ & $\begin{array}{r}-0.0007 \\
(0.010)\end{array}$ & $\begin{array}{c}-0.0011 \\
(0.010)\end{array}$ & $\begin{array}{c}-0.0016 \\
(0.010)\end{array}$ & $\begin{array}{c}-0.0014 \\
(0.010)\end{array}$ \\
\hline Chain & $\begin{array}{c}-0.4400 * * * \\
(0.034)\end{array}$ & $\begin{array}{c}-0.4396 * * * \\
(0.034)\end{array}$ & $\begin{array}{c}-0.4420 * * * \\
(0.035)\end{array}$ & $\begin{array}{c}-0.4415^{* * * *} \\
(0.035)\end{array}$ & $\begin{array}{c}-0.4418 * * * \\
(0.035)\end{array}$ \\
\hline Fast food & $\begin{array}{c}-0.2497 * * * \\
(0.057)\end{array}$ & $\begin{array}{c}-0.2385 * * * \\
(0.061)\end{array}$ & $\begin{array}{c}-0.2382 * * * \\
(0.060)\end{array}$ & $\begin{array}{c}-0.2377^{* * * *} \\
(0.061)\end{array}$ & $\begin{array}{c}-0.2374 * * * \\
(0.061)\end{array}$ \\
\hline Price=“\$\$” & $\begin{array}{c}-0.1760 * * * \\
(0.037)\end{array}$ & $\begin{array}{c}-0.1740 * * * \\
(0.037)\end{array}$ & $\begin{array}{c}-0.1790 * * * \\
(0.038)\end{array}$ & $\begin{array}{c}-0.1785^{* * * *} \\
(0.038)\end{array}$ & $\begin{array}{c}-0.1777^{* * * *} \\
(0.037)\end{array}$ \\
\hline Price=“\$\$\$” & $\begin{array}{c}0.0918 * * \\
(0.035)\end{array}$ & $\begin{array}{c}0.0897 * * \\
(0.035)\end{array}$ & $\begin{array}{c}0.0937^{* *} \\
(0.034)\end{array}$ & $\begin{array}{c}0.0906 * * \\
(0.034)\end{array}$ & $\begin{array}{c}0.0914^{* *} \\
(0.034)\end{array}$ \\
\hline Price=“\$\$\$\$” & $\begin{array}{c}0.4239 * * * \\
(0.076)\end{array}$ & $\begin{array}{c}0.4104 * * * \\
(0.079)\end{array}$ & $\begin{array}{c}0.4152 * * * \\
(0.077)\end{array}$ & $\begin{array}{c}0.4144 * * * \\
(0.076)\end{array}$ & $\begin{array}{c}0.4141^{* * *} \\
(0.076)\end{array}$ \\
\hline Sunday closed & $\begin{array}{l}-0.0578 \\
(0.038)\end{array}$ & $\begin{array}{l}-0.0558 \\
(0.038)\end{array}$ & $\begin{array}{c}-0.0656+ \\
(0.036)\end{array}$ & $\begin{array}{c}-0.0661+ \\
(0.036)\end{array}$ & $\begin{array}{c}-0.0653+ \\
(0.035)\end{array}$ \\
\hline Closed before $7 \mathrm{pm}$ & $\begin{array}{c}0.2293^{* * *} \\
(0.030)\end{array}$ & $\begin{array}{c}0.2546 * * * \\
(0.032)\end{array}$ & $\begin{array}{c}0.2521^{* * *} \\
(0.032)\end{array}$ & $\begin{array}{c}0.2522 * * * \\
(0.032)\end{array}$ & $\begin{array}{c}0.2510 * * * \\
(0.032)\end{array}$ \\
\hline Constant & $\begin{array}{c}1.8157 * * * \\
(0.489)\end{array}$ & $\begin{array}{c}1.7402 * * * \\
(0.485)\end{array}$ & $\begin{array}{c}1.6462 * * * \\
(0.483)\end{array}$ & $\begin{array}{c}2.9861 * * * \\
(0.906)\end{array}$ & $\begin{array}{c}2.5533 * * \\
(0.930)\end{array}$ \\
\hline Fixed Effects, Category (107) & Yes & Yes & Yes & Yes & Yes \\
\hline Number of Cities & 85 & 85 & 85 & 85 & 85 \\
\hline$N$ & 6,072 & 6,072 & 6,072 & 6,072 & 6,072 \\
\hline Log-pseudo-likelihood & -2505.10 & -2503.77 & -2503.03 & -2502.75 & -2502.72 \\
\hline
\end{tabular}




\section{APPENDIX 1. Calculation of Product-level Spanning}

This section provides an illustration of how product-level spanning scores are calculated using a hypothetical example. The front part of the computational process (Tables A1-A3) follows that of Kovács and Johnson (2013). Then, I develop and introduce a novel measure for product-level spanning (product hybridization).

In this hypothetical example, there are six restaurants, each with only two items (Table A1).

Table A 1. Hypothetical Example of a List of Restaurants

\begin{tabular}{c|l|l}
\hline Restaurant & \multicolumn{1}{|c}{ Categories } & \multicolumn{1}{c}{ Menu } \\
\hline 1 & Korean & kimchi bibimbop, bulgogi \\
\hline 2 & Korean & kimchi bibimbop, bulgogi \\
\hline 3 & American & macaroni \& cheese, hamburger \\
\hline 4 & American & macaroni \& cheese, hamburger \\
\hline 5 & Korean, American & kimchi macaroni, bulgogi hamburger \\
\hline 6 & Korean, American & kimchi bibimbop, macaroni \& cheese \\
\hline
\end{tabular}

First, using their cuisine categories and words on the menu, I make a categoryword occurrence table (Table A2). In the case of multiple-category restaurants, I divide 
the occurrence of the menu items by the number of categories the restaurant belongs to, following Kovács and Johnson (2013).

Table A 2. Occurence Table

\begin{tabular}{l|r|r|r|r|r|r|r}
\hline & Kimchi & Bibimbop & Bulgogi & Cheese & Macaroni & Hamburger & Total \\
\hline Korean & 3 & 3.5 & 2.5 & 0.5 & 2.5 & 0.5 & 12.5 \\
\hline American & 1 & 0.5 & 0.5 & 2.5 & 3 & 2.5 & 10 \\
\hline Total & 4 & 4 & 3 & 3 & 5.5 & 3 & 22.5 \\
\hline
\end{tabular}

Next I compute the Jaccard similarity index for all word-category pairs (Table A3) to get typicality scores, using the following formula:

Typicality $($ wordi, categoryj $)=\frac{\#\left(\text { wordi }_{\text {\& category }}\right)}{\#(\text { word } i)+\#(\text { category })-\#(\text { word } i \text { \& category } j)}$

where \# $\left(\right.$ word $_{i} \&$ category $\left._{j}\right)$ denotes the number of times the word $i$ appears on menus in category $j$, \# $\left(\right.$ word $\left._{i}\right)$ denotes the total number of times the word $i$ appears on the menus of all restaurants, and \#(category $)_{j}$ denotes the total number of words in category $j$. For example, the word kimchi appears three times in the Korean category and four times total, and there are 12.5 words in total in the Korean category. Then,

Typicality(“kimchi”, “Korean”) = 3/(4+12.5-3) =0.22 
Table A 3. Word Typicality: The Jaccard Similarity Index for All Word-Category Pairs

\begin{tabular}{l|r|r|r|r|r|r}
\hline & \multicolumn{1}{|l|}{ Kimchi } & \multicolumn{1}{l|}{ Bibimbop } & \multicolumn{1}{l|}{ Bulgogi } & \multicolumn{1}{l}{ Cheese } & Macaroni & Hamburger \\
\hline Korean & 0.22 & 0.27 & 0.19 & 0.03 & 0.16 & 0.03 \\
\hline American & 0.08 & 0.04 & 0.04 & 0.24 & 0.24 & 0.24 \\
\hline
\end{tabular}

From Table A3, I calculate the typicality of each dish in each claimed category by taking the weighted average of the Jaccard similarities of the menu words used in the item description. For example, the typicality of the dish "kimchi macaroni” of Restaurant 5 is $0.19(=(0.22+0.16) / 2)$ in the Korean category and $0.16(=(0.08+0.24) / 2)$ in the American category.

After getting dish typicalities in each category, the highest score among dish typicalities in the categories is chosen for each dish, and these scores are averaged to calculate the average dish typicality of a restaurant (Table A4). For example, "kimchi macaroni” has a higher typicality score in the Korean category than in the American category, so the score in the Korean category is selected. "Bulgogi hamburger" has a higher value in the American category, so the value in the American category is selected. And by averaging the two values (i.e., 0.19 and 0.14 ), the average dish typicality of Restaurant 5 is calculated $(=0.165)$. Because the dishes of Restaurant 5 mix disparate elements together, even the highest dish typicality is relatively low compared to the case of Restaurant 6, which provides a very typical Korean dish and a very typical American dish. Thus, the average dish typicality of Restaurant 5 is lower than that of Restaurant 6 . Finally, because typicality and category spanning are inversely related, I subtract the average dish typicality of a restaurant from 1 to get the degree of product-level spanning for a restaurant. Because the values of product-level spanning are low in absolute number "due to the division by the count of words in the Jaccard formula” (Kovács and Johnson 
2013, 12), for better interpretability I rescale the values to make the maximum observed value of product-level spanning 1 and the minimum 0 .

Table A 4. Dish Typicality and Product-level Spanning of Restaurants 5 and 6

\begin{tabular}{c|c|c|c|c}
\hline \multirow{2}{*}{ Restaurant } & \multicolumn{2}{|c|}{$\mathbf{5}$} & \multicolumn{2}{c}{$\mathbf{6}$} \\
\hline Categories & \multicolumn{2}{|c|}{ Korean, American } & \multicolumn{2}{c}{ Korean, American } \\
\hline Menu & $\begin{array}{c}\text { kimchi } \\
\text { macaroni }\end{array}$ & $\begin{array}{c}\text { bulgogi } \\
\text { hamburger }\end{array}$ & $\begin{array}{c}\text { kimchi } \\
\text { bibimbop }\end{array}$ & $\begin{array}{c}\text { macaroni \& } \\
\text { cheese }\end{array}$ \\
\hline Typicality in Korean & $\begin{array}{c}0.19= \\
(0.22+0.16) / 2\end{array}$ & 0.11 & 0.25 & 0.1 \\
\hline Typicality in American & $\begin{array}{c}0.16= \\
(0.08+0.24) / 2\end{array}$ & 0.14 & 0.06 & 0.24 \\
\hline Dish typicality & 0.19 & 0.14 & 0.25 & 0.24 \\
\hline Average dish typicality & \multicolumn{2}{|c|}{0.165} & \multicolumn{2}{|c}{0.245} \\
\hline Product-level spanning & \multicolumn{2}{|c|}{$\mathbf{0 . 8 3 5}$} & $\mathbf{0 . 7 5 5}$ \\
\hline
\end{tabular}




\section{BIBLIOGRAPHY}

Abernathy W.J., \& Utterback, J.M. (1978). Patterns of innovation in technology. Technology Review 80: 40-47.

Adner, R., \& Zemsky, P. (2006). A demand-based perspective on sustainable competitive advantage. Strategic Management Journal, 27(3), 215-239.

Ahuja, G., \& Yayavaram, S. (2011). Perspective—Explaining Influence Rents: The Case for an Institutions-Based View of Strategy. Organization Science, 22(6), 16311652 .

Aldrich, H. E., \& Fiol, C. M. (1994). Fools rush in? The institutional context of industry creation. Academy of Management Review, 19(4), 645-670.

Aldrich, H., \& Herker, D. (1977). Boundary spanning roles and organization structure. Academy of Management Review, 2(2), 217-230.

Amit, R., Livnat, J., \& Zarowin, P. (1989). The mode of corporate diversification: Internal ventures versus acquisitions. Managerial and Decision Economics, 10(2), 89-100.

Anderson, P., \& Tushman, M.L. (1990). Technological discontinuities and dominant designs: a cyclical model of technological change. Administrative Science Quarterly 35: 604-633.

Barney, J. (1991). Firm resources and sustained competitive advantage. Journal of Management, 17(1), 99-120.

Batagelj, V., \& Bren, M. (1995). Comparing resemblance measures. Journal of Classification, 12(1), 73-90.

Baum, J. A., \& Shipilov, A. V. (2006). Ecological Approaches to Organizations. The SAGE Handbook of Organization Studies, 55.

Baum, J. A., \& Singh, J. V. (1996). Dynamics of organizational responses to competition. Social Forces, 74(4), 1261-1297. 
Bello, D. C., \& Etzel, M. J. (1985). The role of novelty in the pleasure travel experience. Journal of Travel Research, 24(1), 20-26.

Benner, M. J., \& Tripsas, M. (2012). The influence of prior industry affiliation on framing in nascent industries: the evolution of digital cameras. Strategic Management Journal, 33(3), 277-302.

Benzécri, J.P. (1973) Analyse des Données.-Paris: Dunod

Berger, P. G., \& Ofek, E. (1995). Diversification's effect on firm value. Journal of Financial Economics, 37(1), 39-65.

Bianchi, M. (2002). Novelty, preferences, and fashion: when goods are unsettling. Journal of Economic Behavior \& Organization, 47(1), 1-18.

Blau, P. M. (1977). Inequality and heterogeneity: A primitive theory of social structure (Vol. 7). New York: Free Press.

Block, J., Scribner, R., \& DeSalvo, K., (2004). Fast food, race/ethnicity, and income: a geographic analysis. American Journal of Preventive Medicine, 27 (3), 211-217.

Boeker, W., \& Goodstein, J. (1991). Organizational performance and adaptation: Effects of environment and performance on changes in board composition. Academy of Management Journal, 34(4), 805-826.

Bourdieu, P. (1984). Distinction: A Social Critique of the Judgment of Taste. Harvard University Press, Cambridge.

Bowers, A. (2015). Relative comparison and category membership: the case of equity analysts. Organization Science, 26(2): 571-583.

Bradley, R. H., \& Corwyn, R. F. (2002). Socioeconomic status and child development. Annual Review of Psychology, 53(1), 371-399.

Bresnahan, T.F., \& Gordon, R. (Eds.), (1997). The Economics of New Goods. The University of Chicago Press, Chicago.

Bryson, B. (1997). What about the univores? Musical dislikes and group-based identity construction among Americans with low levels of education. Poetics, 25(2), 141156.

Bryson, B. (1996). "Anything but heavy metal": Symbolic exclusion and musical dislikes. American Sociological Review, 884-899.

Carroll, G. R., \& Torfason, M. T. (2011). Restaurant Organizational Forms and Community in the US in 2005. City \& Community, 10(1), 1-24. 
Cattani, G., Porac, J., \& Thomas, H. (2015). Categories and competition. Working paper.

Caves, R. E., \& Porter, M. E. (1977). From entry barriers to mobility barriers: Conjectural decisions and contrived deterrence to new competition*. The Quarterly Journal of Economics, 241-261.

Chamorro-Rivas, J. M. (2000). Plant proliferation in a spatial model of Cournot competition. Regional Science and Urban Economics, 30(5), 507-518.

Chan, K. K., \& Misra, S. (1990). Characteristics of the opinion leader: A new dimension. Journal of Advertising, 19(3), 53-60.

Chandler, A. (1977). The visible hand Cambridge. Massachusetts: s/e.

Chang, S. J. (1996). An evolutionary perspective on diversification and corporate restructuring: Entry, exit, and economic performance during 1981-89. Strategic Management Journal, 17(8), 587.

Chang, S. J., \& Rosenzweig, P. M. (2001). The choice of entry mode in sequential foreign direct investment. Strategic Management Journal, 22(8), 747-776.

Chatterjee, S., \& Wernerfelt, B. (1991). The link between resources and type of diversification: Theory and evidence. Strategic Management Journal, 12(1), 3348.

Christensen, C. M. (1997). The Innovator's Dilemma: The Revolutionary Book that Will Change the Way You Do Business (Collins Business Essentials).

Christensen, H. K., \& Montgomery, C. A. (1981). Corporate economic performance: Diversification strategy versus market structure. Strategic Management Journal, 2(4), 327-343.

Clark KB. (1985). The interaction of design hierarchies and market concepts in technological evolution. Research Policy 14: 235-251.

Corey, L.G., (1971). People who claim to be opinion leaders: Identifying their characteristics by self report. Journal of Marketing, 35: 48-53.

Davis, P. (2006). Spatial competition in retail markets: movie theaters. RAND Journal of Economics, 964-982.

Deephouse, D. L. (1999). To be different, or to be the same? It's a question (and theory) of strategic balance. Strategic Management Journal, 20(2), 147-166.

De Palma, A., Lindsey, R., von Hohenbalken, B., \& West, D. S. (1994). Spatial price and variety competition in an urban retail market: A nested logit analysis. International Journal of Industrial Organization, 12(3), 331-357. 
DiMaggio, P. J., \& Powell, W. W. (1983). The iron cage revisited: Institutional isomorphism and collective rationality in organizational fields. American Sociological Review, 48(2), 147-160.

DiPasquale, D., \& Wheaton, W. C. (1996). Urban economics and real estate markets (Vol. 23, No. 7). Englewood Cliffs, NJ: Prentice Hall.

Dobrev, S. D., Kim, T. Y., \& Hannan, M. T. (2001). Dynamics of Niche Width and Resource Partitioning1. American Journal of Sociology, 106(5), 1299-1337.

Dosi, G. (1988). Sources, procedures, and microeconomic effects of innovation. Journal of economic literature, 1120-1171.

Dowell, G., \& Swaminathan, A. (2000). Racing and back-pedalling into the future: New product introduction and organizational mortality in the US bicycle industry, 1880-1918. Organization Studies, 21(2), 405-431.

Drucker, P. F. (1954). The practice of management. New York Harper \& Row.

Duhaime, I. M., \& Grant, J. H. (1984). Factors influencing divestment decision-making: Evidence from a field study. Strategic Management Journal, 5(4), 301-318.

Duncan, R. \& Weiss, A. (1979). Organizational learning: implications for organization design. Research in Organizational Behaviour, vol. 1, pp. 75-123.

Durand, R., \& Paolella, L. (2013). Category stretching: Reorienting research on categories in strategy, entrepreneurship, and organization theory. Journal of Management Studies, 50(6), 1100-1123.

Fligstein, N., \& Dauter, L. (2007). The sociology of markets. Annual Review of Sociology, 33, 105-128.

Florida, R. (2014). The U.S. cities with the highest levels of income segregation. http://www.citylab.com/work/2014/03/us-cities-highest-levels-incomesegregation/8632/.

Freeman, J., \& Hannan, M. T. (1983). Niche width and the dynamics of organizational populations. American Journal of Sociology, 1116-1145.

Gimeno, J., \& Woo, C. Y. (1999). Multimarket contact, economies of scope, and firm performance. Academy of Management Journal, 42(3), 239-259.

Goldberg, A. (2011). Mapping shared understandings using relational class analysis: the case of the cultural omnivore reexamined. American Journal of Sociology, 116(5), 1397-1436. 
Goldberg, A., Hannan, M. T., \& Kovács, B. (2015). What does it mean to span cultural boundaries? Variety and atypicality in cultural consumption. American Sociological Review, 81(2): 215-241

Granovetter, M. (1985). Economic action and social structure: the problem of embeddedness. American Journal of Sociology, 481-510.

Granqvist, N., Grodal, S., Woolley, J. 2013. Hedging your bests: executives’ market labeling strategies in nanotechnology. Organization Science 24: 395-413.

Greenacre, M. J. (1984). Theory and applications of correspondence analysis. Academic Press, London.

Hall, E. H., \& St John, C. H. (1994). A methodological note on diversity measurement. Strategic Management Journal, 15(2), 153-168.

Hannan, M. T. (2010). Partiality of memberships in categories and audiences. Annual Review of Sociology, 36, 159-181.

Hannan, M.T. (1997) 'Inertia, density and the structure of organizational populations: Entries in European auto- mobileindustries,1886-1981', Organization Studies,18: 193-228.

Hannan, M. T., \& Carroll, G. (1992). Dynamics of organizational populations: Density, legitimation, and competition. Oxford University Press.

Hannan, M. T., \& Freeman, J. (1977). The population ecology of organizations. American Journal of Sociology, 929-964.

Hannan, M. T., \& Freeman, J. (1989). Organization Ecology. Harvard University Press.

Hannan, M. T., Pólos, L., \& Carroll, G. R. (2007). Logics of organization theory: Audiences, codes, and ecologies. Princeton University Press.

Hannerz, U., (1990). Cosmopolitans and locals in world culture. Theory, Culture \& Society 7, 237-251.

Hardin, J. W., and J. M. Hilbe. (2012). Generalized Linear Models and Extensions. 3rd ed. College Station, TX: Stata Press.

Hargadon, A. B., \& Douglas, Y. (2001). When innovations meet institutions: Edison and the design of the electric light. Administrative Science Quarterly,46(3), 476-501.

Hausman, J. A., \& Leonard, G. K. (1997). Superstars in the National Basketball Association: Economic value and policy. Journal of Labor Economics, 15(4), 586-624. 
Haveman, H. A. (1993). Follow the leader: Mimetic isomorphism and entry into new markets. Administrative Science Quarterly, 593-627.

Hayek, F. A. (1994). (First published in 1944.) The road to serfdom (50th anniversary ed.). Chicago: University of Chicago Press.

Helfat, C. E., \& Eisenhardt, K. M. (2004). Inter-temporal economies of scope, organizational modularity, and the dynamics of diversification. Strategic Management Journal, 25(13), 1217-1232.

Hotelling, H. (1929). Stability in Competition. Economic Journal, 39: 41-57.

Hsu, G. (2006). Jacks of all trades and masters of none: Audiences' reactions to spanning genres in feature film production. Administrative Science Quarterly, 51(3), 420450.

Hsu, G., Hannan, M. T., \& Koçak, Ö. (2009). Multiple category memberships in markets: An integrative theory and two empirical tests. American Sociological Review, 74(1), 150-169.

Hsu, G., Negro, G., \& Perretti, F. (2012). Hybrids in Hollywood: a study of the production and performance of genre-spanning films. Industrial and Corporate Change.

Jensen, M. C., \& Murphy, K. J. (1990). Performance pay and top-management incentives. Journal of Political Economy, 225-264.

Kaplan, S., \& Tripsas, M. (2008). Thinking about technology: Applying a cognitive lens to technical change. Research Policy, 37(5), 790-805.

Karamychev, V., \& van Reeven, P. (2009). Retail sprawl and multi-store firms: An analysis of location choice by retail chains. Regional Science and Urban Economics, 39(3), 277-286.

Kashkooli, K., \& Younkin, P. (2014). Stay true to your roots. The effect of audiencedistance on the penalty to spanning for new entrants. Working paper.

Katz-Gerro, T. (2002). Highbrow cultural consumption and class distinction in Italy, Israel, West Germany, Sweden, and the United States. Social forces,81(1), 207229.

Kazanjian, R. K., \& Drazin, R. (1987). Implementing internal diversification: contingency factors for organization design choices. Academy of Management Review, 12(2), 342-354.

Kennedy M. T. (2008). Getting counted, markets, media reality. American Sociological Review 73: 270-295. 
Kennedy, M. T., \& Fiss, P. C. (2013). An ontological turn in categories research: From standards of legitimacy to evidence of actuality. Journal of Management Studies, 50(6), 1138-1154.

Klepper S. (1997). Entry, exit, growth and innovation over the product life cycle. American Economic Review 86: 562 - 583.

Kock, C. J., \& Guillén, M. F. (2001). Strategy and structure in developing countries: Business groups as an evolutionary response to opportunities for unrelated diversification. Industrial and corporate change, 10(1), 77-113.

Kovács, B., \& Hannan, M. T. (2010). The consequences of category spanning depend on contrast. Research in the Sociology of Organizations, 31, 175-201.

Kovács, B., Carroll, G. R., \& Lehman, D. W. (2013). Authenticity and consumer value ratings: Empirical tests from the restaurant domain. Organization Science, 25(2), 458-478.

Kovács, B., \& Johnson, R. (2013). Contrasting alternative explanations for the consequences of category spanning: A study of restaurant reviews and menus in San Francisco. Strategic Organization

Lamont, O. A., \& Polk, C. (2002). Does diversification destroy value? Evidence from the industry shocks. Journal of Financial Economics, 63(1), 51-77.

Lang L, Stultz R. (1994). Tobin's q, corporate diversification, and firm performance. The Journal of Political Economy,102:1248-80

Leahey, E., Beckman, C. M., \& Stanko, T. L. (2014). The impact of interdisciplinarity on scientists' productivity and visibility. Working Paper.

Leclerc, F., Hsee, C., \& Nunes, J. (2005). Narrow focusing: Why the relative position of a good in its category matters more than it should. Marketing Science, 24: 194205.

Leung, M. D. (2014). Dilettante or Renaissance Person? How the Order of Job Experiences Affects Hiring in an External Labor Market. American Sociological Review, 79(1), 136-158.

Leung, M.D., \& Sharkey, A.J. (2014). Out of sight, out of mind? Evidence of perceptual factors in the multiple-category discount. Organization Science. 25:171-184.

Lipsitz, G. (1990). Time passages: Collective memory and American popular culture. U of Minnesota Press.

Litov, L. P., Moreton, P., \& Zenger, T. R. (2012). Corporate strategy, analyst coverage, and the uniqueness paradox. Management Science, 58(10), 1797-1815. 
Lizardo, O. (2005). Can cultural capital theory be reconsidered in the light of world polity institutionalism? Evidence from Spain. Poetics, 33(2), 81-110.

Lounsbury, M., \& Glynn, M. A. (2001). Cultural entrepreneurship: Stories, legitimacy, and the acquisition of resources. Strategic Management Journal,22(6-7), 545-564.

Lounsbury M, Ventresca MJ, Hirsch M. (2003). Social movements, field frames industry emergence: a cultural-political perspective on U.S. recycling. Socio-Economic Review 1: 71-104.

Markides, C. C., \& Williamson, P. J. (1994). Related diversification, core competences and corporate performance. Strategic Management Journal, 15, 149-149.

Marquis, C., \& Raynard, M. (2015). Institutional Strategies in Emerging Markets. Academy of Management Annals, 9(1), 291-335.

Martineau, P. (1958). Social classes and spending behavior. Journal of Marketing, 121130.

McCullagh, P., \& Nelder, J. A. (1989). Generalized linear models (Vol. 37). CRC press.

McGee, J., \& Thomas, H. (1986). Strategic groups: Theory, research and taxonomy. Strategic Management Journal, 7(2), 141-160.

McPherson, M. (1983). An ecology of affiliation. American Sociological Review, 519532.

Meltzer, R. \& J. Schuetz. (2012). Bodegas or Bagel Shops? Neighborhood Differences in Retail and Household Services. Economic Development Quarterly 26: 73 - 96.

Merluzzi, J., \& Phillips, D. J. (2015). The Specialist Discount Negative Returns for MBAs with Focused Profiles in Investment Banking. Administrative Science Quarterly, forthcoming

Meyer, J. W., \& Rowan, B. (1977). Institutionalized organizations: Formal structure as myth and ceremony. American Journal of Sociology, 340-363.

Miller, D. J. (2004). Firms' technological resources and the performance effects of diversification: a longitudinal study. Strategic Management Journal, 25(11), 1097-1119.

Montgomery, C. A. (1979). Diversification, market structure, and firm performance: An extension of Rumelt's model. Purdue University.

Montgomery, C. A. (1985). Product-market diversification and market power. Academy of Management Journal, 28(4), 789-798. 
Myers, J. H., Stanton, R. R., \& Haug, A. F. (1971). Correlates of buying behavior: Social class vs. income. The Journal of Marketing, 8-15.

Navis, C., \& Glynn, M. A. (2010). How new market categories emerge: Temporal dynamics of legitimacy, identity, and entrepreneurship in satellite radio, 19902005. Administrative Science Quarterly, 55(3), 439-471.

Negro, G., Hannan, M. T., \& Rao, H. (2010). Categorical contrast and audience appeal: niche width and critical success in winemaking. Industrial and Corporate Change, 19(5), 1397-1425.

Negro, G., Koçak, Ö., \& Hsu, G. (2010). Research on categories in the sociology of organizations. Research in the Sociology of Organizations, 31, 3-35.

Nelson, R. R., \& Winter, S. G. (1973). Toward an evolutionary theory of economic capabilities. The American Economic Review, 440-449.

Nerlove, M., (1995). Hedonic price functions and the measurement of preferences: the case of Swedish wine consumers. European Economic Review 39, 1697-1716.

Ollivier, M. (2008). Modes of openness to cultural diversity: Humanist, populist, practical, and indifferent. Poetics, 36(2), 120-147.

Papke L. E, \& Wooldridge J. M. (1996). Econometric methods for fractional response variables with an application to 401(k) plan participation rates. Journal of Applied Econometrics 11 : 619-632.

Parsa, H. G., Self, J. T., Njite, D., \& King, T. (2005). Why restaurants fail. Cornell Hotel and Restaurant Administration Quarterly, 46(3), 304-322.

Peng, M. W., Sun, S. L., Pinkham, B., \& Chen, H. (2009). The Institution-Based View as a Third Leg for a Strategy Tripod. The Academy of Management Perspectives, 23(3), 63-81.

Penrose, E. T. (1959). The Theory of the Growth of the Firm, Blackwell, Oxford.

Peterson, R. A. (2005). Problems in comparative research: The example of omnivorousness. Poetics, 33(5), 257-282.

Peterson, R. A. (1997). The rise and fall of highbrow snobbery as a status marker. Poetics, 25(2), 75-92.

Peterson, R. A. (1992). Understanding audience segmentation: From elite and mass to omnivore and univore. Poetics, 21(4), 243-258.

Peterson, R. A., \& Kern, R. M. (1996). Changing highbrow taste: from snob to omnivore. American Sociological Review, 900-907. 
Peterson, R. A., \& Simkus, A. (1992). How Musical Tastes Mark Occupational Status Groups. Cultivating Differences: Symbolic Boundaries and the Making of Inequality, 152.

Pfeffer, J. S., \& Salancik, G. (1978). The external control of organizations: a resource dependence perspective. New York: Harper \& Row.

Phillips, D. J., \& Zuckerman, E. W. (2001). Middle-Status Conformity: Theoretical Restatement and Empirical Demonstration in Two Markets1. American Journal of Sociology, 107(2), 379-429.

Pontikes, E. G. (2012). Two Sides of the Same Coin How Ambiguous Classification Affects Multiple Audiences' Evaluations. Administrative Science Quarterly, 57(1), 81-118.

Popielarz, P. A., \& Neal, Z. P. (2007). The niche as a theoretical tool. Sociology, 33(1), 65.

Porac, J., Rosa, J. A., Spanjol, J., \& Saxon, M. S. (2001). America’s family vehicle: path creation in the US minivan market. Path Dependence and Creation. Lawrence Earlbaum Associates, Mahwah, NJ, 213-242.

Porac, J. F., Wade, J. B., \& Pollock, T. G. (1999). Industry categories and the politics of the comparable firm in CEO compensation. Administrative Science Quarterly, 44(1), 112-144.

Porter, M. E. (1995). The competitive advantage of the inner city. Harvard Business Review, 73(3), 55-71.

Porter, M. E. (1980). Competitive strategy: Techniques for analyzing industries and competition. New York.

Priem, R. L. (2007). A consumer perspective on value creation. Academy of Management Review, 32(1), 219-235.

Prieur, A., Rosenlund, L., \& Skjott-Larsen, J. (2008). Cultural capital today: A case study from Denmark. Poetics, 36(1), 45-71.

Rao H. (2008). Market Rebels: How Activists Make or Break Radical Innovations. Princeton University Press: Princeton, NJ.

Rao, H., Monin, P., \& Durand, R. (2005). Border crossing: Bricolage and the erosion of categorical boundaries in French gastronomy. American Sociological Review, 70(6), 968-991.

Rogers, E., (1995). Diffusion of Innovations. Free Press, New York. 
Roose, H., van Eijck, K., \& Lievens, J. (2012). Culture of distinction or culture of openness? Using a social space approach to analyze the social structuring of lifestyles. Poetics, 40(6), 491-513.

Rosa, J. A., Porac, J. F., Runser-Spanjol, J., \& Saxon, M. S. (1999). Sociocognitive dynamics in a product market. The Journal of Marketing, 64-77.

Rosenkopf, L., \& Nerkar, A. (2001). Beyond local search: Boundary-spanning, exploration, and impact in the optical disk industry. Strategic Management Journal, 22(4), 287-306.

Rumelt, R. P. (1974). Strategy, Structure, and Economic performance. Harvard University Press.

Salop, S. C. (1979). Monopolistic competition with outside goods. The Bell Journal of Economics, 141-156.

Santos FM, Eisenhardt KM. (2009). Constructing markets, shaping boundaries: entrepreneurial power in nascent fields. Academy of Management Journal 52: 643-671.

Schlosser, E. (2001). Fast Food Nation. New York: Houghton-Mifflin.

Schumpeter, J. A. (1934). The theory of economic development: An inquiry into profits, capital, credit, interest, and the business cycle (Vol. 55). Transaction Publishers.

Scott J. (1982). Multimarket contact and economic performance. Review of Economics and Statistics, 64: 368-375

Schuetz, J., Kolko, J., \& Meltzer, R. (2012). Are poor neighborhoods "retail deserts”? Regional Science and Urban Economics, 42(1), 269-285.

Simmel, G. (1957). Fashion. American Journal of Sociology, 541-558.

Sloane, D.C., Lewis, L.B., \& Nascimento, L.M., (2005). Assessing healthy food options in South Los Angeles restaurants. American Journal of Public Health, 95 (4), 668-673.

Smith, E. B. (2011). Identities as lenses: How organizational identity affects audiences' evaluation of organizational performance. Administrative Science Quarterly, 56(1), 61-94.

Smith, E. B., \& Chae, H. (2015). "We do what we must, and call it by the best names": Can deliberate names offset the consequences of organizational atypicality? Strategic Management Journal, Forthcoming.

Sohn, M. W. (2001). Distance and cosine measures of niche overlap. Social Networks, 23(2), 141-165. 
Stern, N. (1972). The optimal size of market areas. Journal of Economic Theory, 4(2), 154-173.

Suarez, F. F., Grodal, S., \& Gotsopoulos, A. (2015). Perfect timing? Dominant category, dominant design, and the window of opportunity for firm entry. Strategic Management Journal, 36(3), 437-448.

Tajfel, H., \& J. C.Turner. (1986). The social identity theory of inter-group behavior. In S. Worchel and W. Austin (eds.), The Social Psychology of Intergroup Relations, 2d ed.: 7-24. Chicago: Nelson-Hall.

Takaki, R. (1993). A different mirror: A multicultural history of America. Boston: Little, Brown \& Company.

Teece, D. J. (1980). Economies of scope and the scope of the enterprise. Journal of Economic Behavior \& Organization, 1(3), 223-247.

Tepper, S. J., \& Hargittai, E. (2009). Pathways to music exploration in a digital age. Poetics, 37(3), 227-249.

Thompson, J. D. (1967). Organizations in action: Social science bases of administration. New York: McGraw Hill.

Tirole, J. (1988). The Theory of Industrial Organization. MIT Press.

Tushman, M. L., \& Anderson, P. (1986). Technological discontinuities and organizational environments. Administrative Science Quarterly, 439-465.

Vinokurova, N. D. (2015) “Negotiating Market Boundaries: Fitting New Products into Existing Categories”. Working Paper

Warde, A., Wright, D., \& Gayo-Cal, M. (2008). The omnivorous orientation in the UK. Poetics, 36(2), 148-165.

Wernerfelt, B., \& Montgomery, C. A. (1988). Tobin's q and the importance of focus in firm performance. The American Economic Review, 246-250.

Westphal, J. D., \& Graebner, M. E. (2010). A matter of appearances: How corporate leaders manage the impressions of financial analysts about the conduct of their boards. Academy of Management Journal, 53(1), 15-44.

White, H. C. (2008). Identity and control: How social formations emerge. Princeton University Press.

Williams, D. R., \& Collins, C. (1995). US socioeconomic and racial differences in health: patterns and explanations. Annual Review of Sociology, 349-386. 
Wry, T., Lounsbury, M., \& Jennings, P. D. (2014). Hybrid vigor: securing venture capital by spanning categories in nanotechnology. Academy of Management Journal, 57(5), 1309-1333.

Vergne, J. P., \& Wry, T. (2014). Categorizing categorization research: Review, integration, and future directions. Journal of Management Studies, 51(1), 56-94.

Zander, I., \& Zander, U. (2005). The Inside Track: On the Important (But Neglected) Role of Customers in the Resource-Based View of Strategy and Firm Growth. Journal of Management Studies, 42(8), 1519-1548.

Zhou, Y. M. (2011). Synergy, coordination costs, and diversification choices. Strategic Management Journal, 32(6), 624-639.

Zucker, L. G. (1977). The role of institutionalization in cultural persistence. American Sociological Review, 726-743.

Zuckerman, E. W. (1999). The categorical imperative: Securities analysts and the illegitimacy discount. American Journal of Sociology, 104(5), 1398-1438.

Zukin, S., Trujillo, V., Frase, P., Jackson, D., Recuber, T., \& Walker, A., (2009). New retail capital and neighborhood change: boutiques and gentrification in New York City. City and Community, 8 (1), 47-64. 